4 nordon 



\section{Nordisk utdanningsforskning. Sentrale kjennetegn - nye muligheter}

Jorunn Spord Borgen, Bjørn Stensaker og Lars Geschwind

TemaNord 2010:540 
Nordisk utdanningsforskning. Sentrale kjennetegn - nye muligheter

TemaNord 2010:540

(C) Nordisk ministerråd, København 2010

ISBN 978-92-893-2058-0

Trykk: Kailow Express ApS

Opplag: 0

Denne rapporten er gitt ut med finansiell støtte fra Nordisk ministerråd. Innholdet i rapporten avspeiler imidlertid ikke nødvendigvis Nordisk ministerråds synspunkter, holdninger eller anbefalinger.

Publikasjonen er tilgjengelig som Print on Demand (PoD) og kan bestilles på www.norden.org/order. Du finner flere publikasjoner på www.norden.org/publikationer.

Printed in Denmark

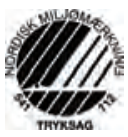

Nordisk ministerråd

Ved Stranden 18

DK-1061 København K

Telefon (+45) 33960200

Fax (+45) 33960202

\section{Nordisk råd}

Ved Stranden 18

DK-1061 København K

Telefon (+45) 33960400

Fax (+45) 33111870

\section{Det nordiske samarbeidet}

Det nordiske samarbeid er en av verdens mest omfattende regionale samarbeidsformer. Samarbeidet omfatter Danmark, Finland, Island, Norge og Sverige, samt de selvstyrende områdene Færøyene, Grønland og Åland.

Det nordiske samarbeid er både politisk, økonomisk og kulturelt forankret, og er en viktig medspiller i det europeiske og internasjonale samarbeid. Det nordiske fellesskap arbeider for et sterkt Norden i et sterkt Europa.

Det nordiske samarbeid ønsker å styrke nordiske og regionale interesser og verdier i en global omverden. Felles verdier landene imellom er med til å styrke Nordens posisjon som en av verdens mest innovative og konkurransekraftige regioner. 


\section{Innhold}

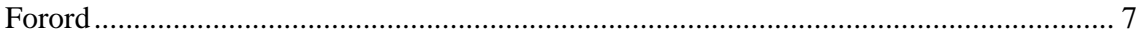

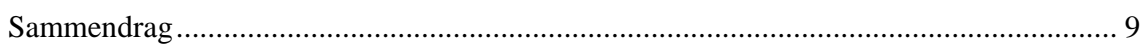

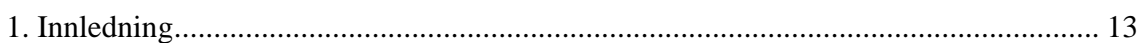

1.1 Mulighetsstudie om nordisk utdanningsforskning........................................... 13

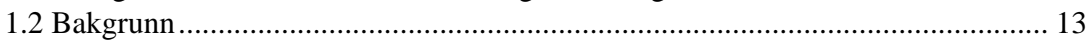

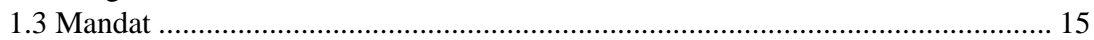

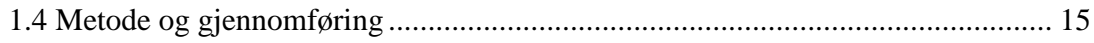

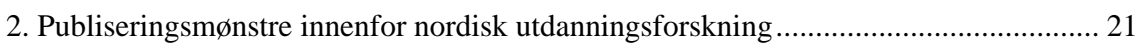

2.1 Identifisering av publiseringsmønstre................................................................. 21

2.2 Noen sentrale kjennetegn ved nordisk utdanningsforskning som publiseres

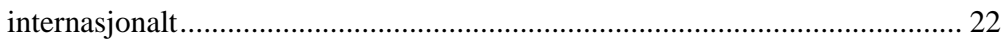

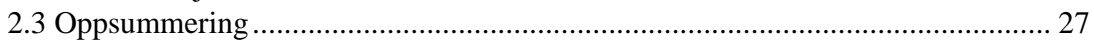

3. Forskningsprogrammer i Norden i 2004-2009, samt deres formidlingsstrategi .......... 29

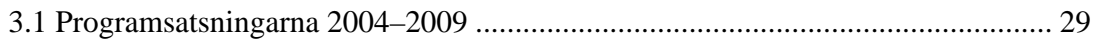

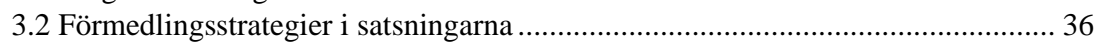

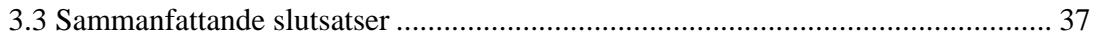

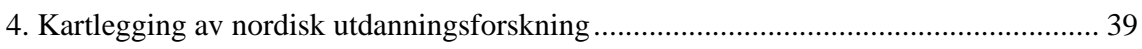

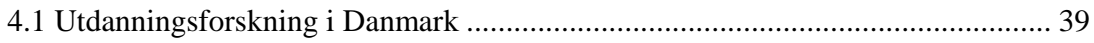

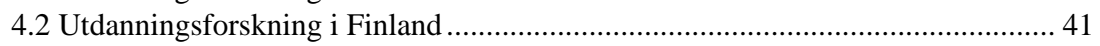

4.3 Utdanningsforskning på Færøyene ................................................................. 44

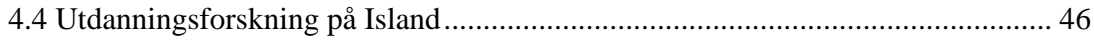

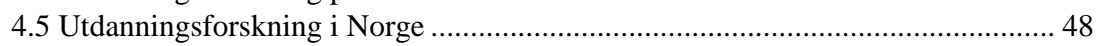

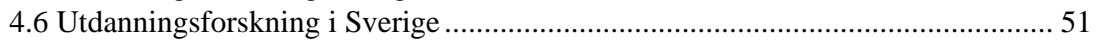

4.7 Sammenfatning av noen sentrale kjennetegn........................................................ 53

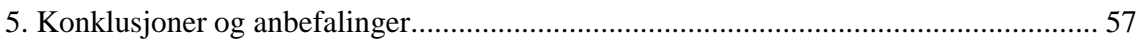

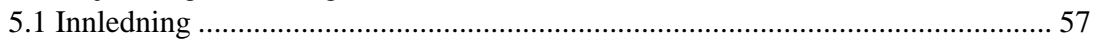

5.2 Mulighetsrommet innenfor nordisk utdanningsforskning ...................................... 58

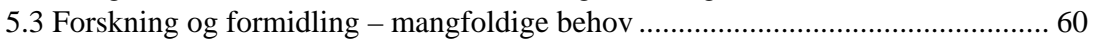

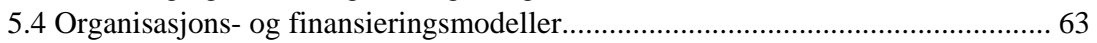

5.5 Noen forslag til konkrete tematiske prioriteringer ................................................... 65

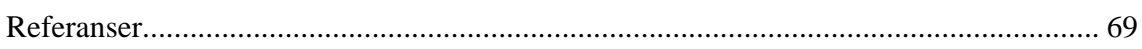

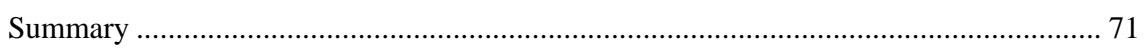

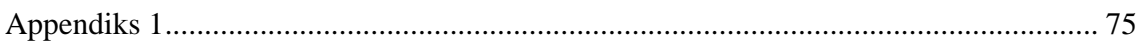

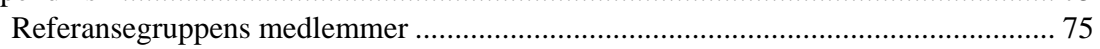

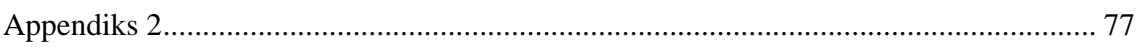

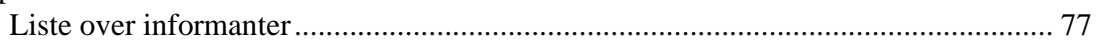

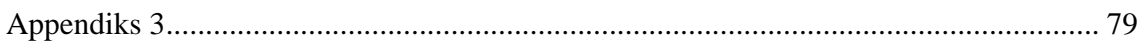

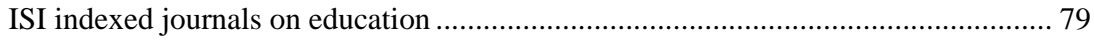

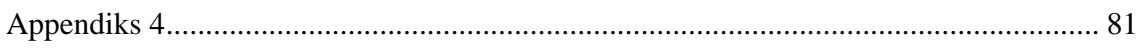

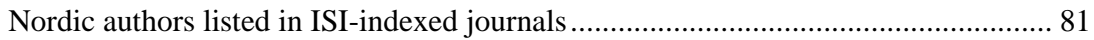





\section{Forord}

Uddannelsesforskning og -formidling af denne type forskning anses for at være af stor betydning, såvel nationalt som i nordisk sammenhæng, og uddannelsesspørgsmål er generelt blevet vigtigere for de nordiske lande. Gennem den globale konkurrence om kundskab og kvalificeret arbejdskraft er uddannelse kommet højere op den politiske agenda. Som følge af den stigende politiske interesse for uddannelsesforskning er der forventninger om, at forskningen skal bidrage til løsning af konkrete problemer i uddannelsessektoren. I forhold til den globale konkurrence er det påfaldende ens problemer, der skal løses i de nordiske lande. Eksempler på sådanne problemer er frafald, faldende antal studerende og dårlige resultater i internationale målinger.

Flere internationale sammenligninger viser, at Norden ligger langt fremme når det gælder uddannelse. For eksempel viser „Eurostat regional yearbook 2009“, at de nordiske lande er ledende i Europa på en række områder indenfor uddannelse. Men i en tid hvor „alle“ har tilgang til kundskab om, hvad der kan give konkurrencemæssige fortrin, er dagens styrkepositioner ikke givet i fremtiden. Norden har imidlertid grundlæggende styrker med sin relativt homogene og godt uddannede befolkning. Højt niveau i alle dele af uddannelsessystemet og høj kompetence om læring vil kunne give ophav til nye styrkepositioner - og dette kan uddannelsesforskning og formidling hjælpe med.

Embedsmandskomiteen for uddannelse og forskning (EK-U) under Nordisk Ministerråd (NMR) besluttede på sit møde i december 2008, at der skulle gennemføres et mulighedsstudie som underlag for en eventuel større satsning på uddannelsesforskning og -formidling.

Opdragets hovedformål har været, at undersøge mulighederne for et nordisk uddannelsesforsknings- og formidlingsinitiativ gennem en kortlagning af igangverende og planlagte uddannelsesforskningsinitiativer $i$ de nordiske lande og selvstyrende områder, samt indhente synspunkter om hvilke felter og i hvilken form et eventuelt nordisk initiativ kan vare hensigtsmassigt.

Rapporten fastslår, at det nordiske uddannelsesforskningsfelt kendetegnes af et stort mangefold i disciplintilknytning og perspektiver, i forskningsfokus og forskningsmetodik, samt i publicering og formidling. Forfatterne mener, at denne situation bidrager til, at feltet uddannelsesforskning kan være vanskelig at definere præcist og dermed afgrænse. Rapporten peger imidlertid på en del konkrete områder, hvor der både fagligt og politisk kan skabes stor nordisk merværdi.

Ved siden af det fokus på uddannelsesspørgsmål, som den globale konkurrence har skabt, er der mange argumenter der taler for et nordisk 
initiativ indenfor uddannelsesforsknings- og -formidlingsfeltet. Det forhold at meget af uddannelsesforskningen i Norden bygger på et fælles værdigrundlag, at man kan identificere en del identiske udfordringer knyttet til uddannelsessystemernes funktionalitet, at meget af forskningen er lokal og derfor meget lidt synlig i en nordisk kontekst samt at samarbejde mellem forskere i dag synes at foregå lige så meget udenfor som indenfor en nordisk kontekst - tyder på, at en større grad af samarbejde og øget koordinering på feltet, kan give en nordisk merværdi på en række områder.

Jeg håber, at rapporten kan skabe grundlag for inspiration og læring, samt bidrage som grundlag for indspil til og vurderingen af et fremtidigt nordisk initiativ indenfor uddannelsesforskning og -formidling.

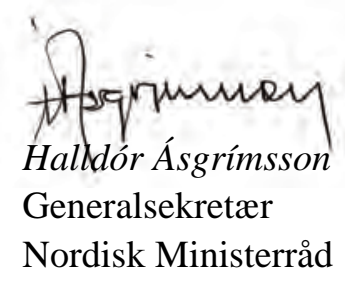




\section{Sammendrag}

I 2009 ga Nordisk ministerråd (NMR) NIFU STEP i samarbeid med Technopolis i oppdrag å utføre en studie av nordisk utdanningsforskning og formidlingen av denne. Bakgrunnen for prosjektet er at Nordisk ministerråd vurderer å ta initiativ til ytterligere å bygge ut det nordiske forsknings- og utdanningssamarbeid (jfr. Sektorplan for Islands formannskapsprogram for Nordisk ministerråds samarbeid om forskning, kultur og utdannelse 2009). Oppdraget har hatt som hovedformål å undersøke mulighetene for et nordisk utdanningsforsknings- og formidlingsinitiativ gjennom å kartlegge igangværende og planlagte utdanningsforskningsinitiativer i de nordiske landene og selvstyrende områder, samt innhente synspunkter på hvilke felter og i hvilken form et eventuelt nordisk initiativ kan være hensiktsmessig. Studien bygger både på kvantitative (bibliografidata) og kvalitative data - en rekke intervjuer med forskere, beslutningstakere og personer i forskningsfinansierende instanser i de nordiske land. I tillegg er det gjennomført en kartlegging (dokumentanalyse) av de ulike politiske og nasjonale initiativ i forhold til utdanningsforskningen i perioden 2004-2008.

Basert på både de bibliografiske data og intervjuer med sentrale forskere på feltet, kan det slås fast at det nordiske utdanningsforskningsfeltet kjennetegnes av stort mangfold både i disiplintilknytning og perspektiver, i forskningsfokus og forskningsmetodikk, publisering og formidling. Denne situasjonen bidrar til at feltet utdanningsforskning kan være vanskelig å presist definere og avgrense. Studien har valgt å fokusere på forskningsaktiviteten innenfor universiteter, høyskoler og institutter (som er de mest sentrale institusjonelle aktørene), og publiseringsaktiviteten der. Samtidig bør det understrekes at formålet med studien ikke er å gjennomføre en fullstendig kartlegging av utdanningsforskningen, men fremheve eventuelle generelle trekk ved denne forskningen. Svakheter i dekningsgraden knyttet til de bibliografiske data gjør at man bør utvise varsomhet når det gjelder validiteten av våre funn knyttet til utdanningsforskningsfeltet som sådan. Med disse forbehold synes det likevel å være en tendens til at det er visse temaer innen utdanningsforskning hvor Norden markerer seg internasjonalt. Dette gjelder særlig studier av utdanning og teknologi, studier av høyere utdanning, og det man kan kalle curriculumstudier og forskning på undervisning og læring.

Ser man nærmere på forskningen i de enkelte land, gir mange av informantene et bilde av at utdanningsforskningen ofte har vokst frem i forhold til opplæringen og lærerutdanningen, og at oppbyggingen av pedagogikkfaget som akademisk disiplin har vært viktig for å besvare og bidra til kunnskapsbehovene i sektoren. Et trekk i flere av landene kan 
synes å være et ambivalent og spenningsfylt forhold mellom lærerutdanningen og det akademiske pedagogikkfaget, og her har landene ulike historiske prosesser der politikkutforming og ressurstilgang, autonomi i oppbyggingen av læresteder og miljøer, og ikke minst enkeltpersoner spiller sammen. Utviklingen av forskningsfeltet i nyere tid viser at nordisk utdanningsforskning også preges av endringer i politikkutforming og -fokus. Dette har gjenspeilt seg i en mer markant interesse for å finansiere utdanningsforskning i Norden gjennom ulike programsatsninger. En konsekvens er at man kan se en økt bredde i utdanningsforskningens fokus utdanningsforskning har blitt et mer sektorovergripende, tverrfaglig og flerfaglig forskningsfelt som foregår i alle samfunnsområder og i et livslangt perspektiv. Ulike programsatsninger kan i høy grad sies å ha spilt en sterk rolle i denne utviklingen.

Fordi nordisk utdanningsforskning nettopp er kjennetegnet av så mye variasjon og bredde, er en konsekvens at det ikke bare er ett, men mange mulighetsrom for et nordisk initiativ på dette feltet. Samtidig bør de mulige initiativ kanskje innrettes på ulik måte siden behovene og ambisjonene for de tematiske områdene innenfor utdanningsforskningen er så forskjellige. Mens enkelte områder har en lang historie og gjerne er orientert mot nasjonale og lokale agendaer, er andre av nyere karakter og har en orientering som er mer internasjonal enn eksplisitt nordisk. Basert på det forhold at en eventuell satsning på utdanningsforskning i nordisk regi relativt raskt bør kunne gi konkrete resultater, og sannsynligvis også vil ha begrenset med ressurser tilgjengelig, kan det argumenteres for at en slik satsning i første omgang bør konsentreres om forskning som allerede har høy kvalitet og eventuelt som kan utfylles med en komparativ dimensjon mellom landene eller mellom nordiske og andre land.

Hvis man i første omgang skal prioritere forskning av høy kvalitet som gjerne kan bygges ut med et komparativt tilsnitt, synes kartleggingen av aktiviteten i Norden å peke på en del konkrete felt hvor det både faglig og politisk kan skapes stor nordisk merverdi:

- De nordiske PISA-funnene har bidratt til diskusjoner om hva slags kunnskapssyn disse funnene gjenspeiler, og hvorvidt de nordiske velferdssamfunn representerer noen særtrekk som kan bidra til å forklare resultatene i opplæringen. Her synes det å foreligge mange spennende muligheter for analyser som går «beyond PISA».

- Studier av ny teknologi i læringssammenheng, herunder bruk av IKT synes å være et felt hvor man i Norden er langt fremme. Tatt i betraktning at de ulike nordiske landene har valgt svært ulike strategier for hvilken plass og ressurser teknologi og IKT får i opplæringen, kan dette være et interessant område for komparative studier.

- Studier av høyere utdanning der mange av de nordiske land har initiert store reformer det siste tiåret, men der denne sektoren fremdeles står 
overfor viktige utfordringer knyttet til globalisering, kunnskapsoverføring og kunnskapsutvikling.

- Forskning på lærerutdanning spesielt knyttet til de nye rammebetingelser og organiseringsformer ved lærestedene, og forholdet mellom lærerutdanning og forskning på denne.

Avslutningsvis vil vi påpeke at alle forslagene er tentative og ment som grunnlag for videre diskusjon. De er her derfor heller ikke rangert eller koblet direkte til de finansielle strukturene som det nordiske forskningssamarbeidet er innrammet av, og der organiseringen av eventuelle nordiske initiativ også må avklares med de enkelte lands myndigheter. 



\section{Innledning}

\subsection{Mulighetsstudie om nordisk utdanningsforskning}

På oppdrag fra Nordisk ministerråd (NMR) gjennomfører NIFU STEP i samarbeid med Technopolis i Stockholm i 2009 en mulighetsstudie om nordisk utdanningsforsknings- og formidlingsinitiativ, basert på en generell beskrivelse av det nordiske utdanningsforskningsfeltet og noen kjennetegn ved dette. Prosjektet skal være et viktig skritt for å identifisere både nordisk drivkraft og nordisk styrke innenfor utdanningsforskningen i de nordiske landene. Bakgrunnen er at Nordisk ministerråd ønsker å spille en sentral rolle i forhold til ytterligere å bygge ut det nordiske forsknings- og utdanningssamarbeidet (jfr. Sektorplan for Islands formannsskapsprogram for Nordisk ministerråds samarbeid om forskning, kultur og utdannelse 2009). Oppdraget har som hovedformål å undersøke mulighetene for et nordisk utdanningsforsknings- og formidlingsinitiativ gjennom å kartlegge igangværende og planlagte utdanningsforskningsinitiativer i de nordiske landene og selvstyrende områder.

I dette prosjektet inngår Danmark, Finland, Færøyene, Island, Norge og Sverige, mens Grønland og Åland har valgt ikke å inngå. Prosjektet er en strategisk mulighetsanalyse og har ikke målsetting om å være en fullstendig kartlegging eller evaluering av nordisk utdanningsforskning.

\subsection{Bakgrunn}

De senere år har Nordisk ministerråd tatt stadig flere initiativ for å fremme nordisk samarbeid om forskning. Ifølge MR-U:s strategi for utdannings- og forskningsområdet 2008-2010, Norden en ledende, dynamisk kunnskaps- och kompetanseregion heter det at Nordisk ministerråds samarbeid innen utdanning og forskning skal bidra til at Norden skal være en foregangsregion for kompetanseutvikling og forskning med vekt på å utvikle de menneskelige ressursene, samt utvikle og understøtte det nordiske samarbeidet og fremme nordiske interesser på den internasjonale arena. Samarbeidet skal styrke konkurranseevnen globalt, både for de enkelte land og for de selvstyrende områdende (Norden 2009). Det nordiske forskningssamarbeidet koordineres av NordForsk, som ble etablert $\mathrm{i}$ 2005. Foruten samarbeid i forsknings-nettverk, forskerutdanning og forskerskoler, finnes i dag også egne nordiske forskningsprogram og nordiske sentra for fremragende forskning. Eksempler på dette er nordisk forskningsprogram i epidemologi, i transport og logistikk, et eget klimaforskningsprogram, program for velferdsforskning så vel som senter for frem- 
ragende forskning i velferd. I dag legges det i større grad også opp til samarbeid rundt forskningsinfrastruktur; om vitenskapelig utstyr, infrastruktur og strategier for nordisk samarbeid rundt deltakelse og prioriteringer i forhold til internasjonale prosesser (Improving research capabilities, Norden: NordForsk 2008). Initiativet om en nordisk mulighetsstudie for utdanningsforskning kan forstås på denne bakgrunn.

Utdanningsforskning er et mangesidig og spenningsfylt felt i nordisk sammenheng, noe som har sammenheng med at utdanning omfatter alle samfunnsområder, og fordi utdanning og læring har vært og er sentral i enhver samfunnsutvikling, og er en av de største sektorer i nordiske land. Utdanningssektorens kunnskapsbehov har tradisjonelt vært styrt fra fagdepartementene i hvert land. Dette sektorforskningsprinsippet besvarer flere kunnskapsbehov; generell kunnskapsberedskap, programforskning koblet til sektorens målsettinger, og bidrag til å løse konkrete og kortsiktige oppgaver knyttet til den politisk-administrative dagsorden. Imidlertid har det tradisjonelt vært svake tradisjoner for bruk av forskning i sektoren, og politisk svak interesse for forskning og forsøk. Samtidig har forskersamfunnet tradisjonelt hatt et reservert forhold til kunnskapsetterspørselen, og svak bevissthet om politisk påvirkning.

Dagens utfordringer angående utdanningsforskning er knyttet til flere forhold. Det har skjedd en desentralisering av styring og autonomi i utdanningssektoren, og nye virkemidler for målstyring har gitt nye utfordringer i forholdet mellom politikkutforming og det utførende feltet. Det er i dag endringer i måten politikk blir til på, og flere beslutninger skjer i skjæringsfeltet mellom overnasjonalt, nasjonalt og lokalt nivå. Utdanning er dessuten ikke bare noe som foregår innenfor opplæringen og i høyere utdanning, men er sektorovergripende og foregår på alle samfunnsområder og i et livslangt perspektiv.

Tidligere studier av utdanningsforskning i nordiske land (se for eksempel Aasen m. fl. 2005, Askling 2006, Borgen m. fl. 2007, Borgen m. fl. 2009) har vist at for å gjenspeile utdanningsforskningens endrede formål må utdanningsforskning ses som et felt på tvers av disipliner og fagfeltinndelinger. En bred definisjon av utdanningsforskning må være basert på to hovedprinsipper:

- Forskningen skal ha et anvendt rasjonale, basert på forskningspolitisk begrunnelse (relevans)

- Forskningen må samtidig sikre sin uavhengighet (kvalitet)

Utdanningsforskningen må på ulike måter håndtere spennet mellom kvalitet og relevans. En for sterk vektlegging på relevanskravet kan føre til at definisjonene av kvalitet blir mangetydig, og at det blir mindre rom for kritisk forskning og originalitet. Men også det motsatte kan forekomme, at for sterk vekt på forskningsinterne kvalitetskrav kan føre til at forskningen forblir tilbaketrukket i forhold til samfunnet. Denne mulighetsstu- 
dien vil kunne bidra til å belyse hvordan utdannings-forskningen i de nordiske landene balanserer dette spennet.

\subsection{Mandat}

Mandatet for denne mulighetsstudien går ut på å gi en overordnet beskrivelse av utdanningsforskningsfeltet med utgangspunkt i en identifisering av landenes forskningsfinansierende miljøer, landenes fagmiljøer og den forskning som er gjort på feltet. I følge mandatet skal det foretas en vurdering av forskningsfeltet med tanke på å identifisere styrkeposisjoner, herunder undersøke hvilke områder som har potensial for å bli toneangivende innenfor utdanningsforskning i Norden. Videre skal det identifiseres mulige forskningsområder som kan egne seg til felles nordisk forskningsinnsats. Forskningsformidlingen innenfor feltet skal analyseres med tanke på eventuelle tiltak som kan tas på nordisk nivå, og som kan gi en klar merverdi for landene.

Det skal også gjøres en vurdering av mulige alternative modeller for et felles nordisk initiativ til utdanningsforskning og formidling, herunder å undersøke betingelsene for en mulig nordisk koordinering av et eventuelt fremtidig utdanningsforskningsprogram. Denne delen skal inneholde en vurdering av omfang, tematikk, finansiering og organisering, såfremt man finner grunnlag for å foreslå initiativer.

Det er oppnevnt en nordisk referansegruppe, sammensatt av en representant fra hvert av landene som inngår i dette prosjektet. Referansegruppens medlemmer er oppnevnt av de nordiske lands utdanningsdepartementer (se Appendiks 1).

I den grad det er relevant for studiet, skal planlagte initiativer i EU og andre internasjonale fora med relevans for Norden inndras og vurderes.

\subsection{Metode og gjennomføring}

På bakgrunn av tidligere studier vet vi at utdanningsforskningsfeltet kjennetegnes av stort mangfold både i disiplintilknytning og perspektiver, i forskningsfokus og forskningsmetodikk. Identifiseringen av forskningsfeltet krever derfor både kjennskap til feltets mangfold, men også en systematisk metodisk tilnærming som kan belyse mønstre på et mer overordnet nivå. Utdanningsforskning er et tverrfaglig felt som ofte vil gå på tvers av fagfeltinndelinger. Avgrenset fagkunnskap vil derfor ikke være tilstrekkelig for å kartlegge feltet. Samtidig er prosjektets rammer (økonomisk og tidsmessig) av en slik art at en fullstendig kartlegging av all aktivitet i Norden på utdanningsforskningsfeltet ikke er mulig. Denne kartleggingen av nordisk utdanningsforskning vil derfor være av en mer eksplorerende karakter, og består av fire deler: 
- Bibliometrisk identifikasjon av noen aktive forskere/miljøer i Norden for å belyse publiseringsmønstre innenfor nordisk utdanningsforskning

- Identifisering av sentrale forskningsprogrammer i Norden i 2004-2009, samt deres formidlingsstrategi

- Kartlegging av aktivitet/profil på utdanningsforskningen i nordiske lande

- Diskusjon av det nordiske utdanningsforskningsfeltet og identifisering av mulighetene for nordiske initiativ.

Utgangspunktet for vår kartlegging vil være at forskningsaktiviteten i hovedsak utøves innenfor en institusjonell kontekst (universiteter, høyskoler og institutter), og at kartleggingen i hovedsak må fokusere på forskning som foregår ved slike institusjoner. Innenfor denne institusjonelle rammen vil aktive forskere som regel ha mange oppgaver knyttet til både forskning, undervisning, veiledning og annen formidling. Forskningsaktivitetens mange sider består bl.a. av prosjektutvikling, prosjektfinansiering, prosjektgjennomføring, og resultatformidling i ulike kanaler, og forskerne får i dag incentiver til å publisere i både etablerte faglige, men også tverrfaglige tidsskrifter og bøker, i tillegg til et bredt spekter av allmennrettet formidling, undervisning, etc.

Tidligere kartlegginger av utdanningsforskningen i nordiske land viser at formidlings- og publiseringsaktiviteten i feltet er bred og mangfoldig (Borgen m. fl. 2007, Sivertsen 2007, Gunnes 2009). Selv om kartlegging er enklere i Norge enn i de øvrige nordiske landene takket være det innførte systemet for innsamling og strukturering av publikasjonsdata fra forskningen (se Sivertsen 2007), er det komplekst å kartlegge alle former for resultatformidling på en tilfredsstillende måte med dagens rapporteringssystemer i de nordiske landene. Vi har derfor i stedet startet med å stille spørsmålet om hva man internasjonalt vil kunne finne om man ønsker å bli bedre kjent med nordisk utdanningsforskning. Et internasjonalt hjelpemiddel i denne sammenhengen er å søke ISI databasen og bruke søkeordet education samt adresse på forfatter i et nordisk land. Vi har på denne bakgrunn valgt å innkretse feltet gjennom å bruke bibliometrisk analyse som metode for å identifisere noen aktive forskere/miljøer på utdanningsforskningsfeltet. Det strategiske utvalget er utdanningsforskningstidsskrifter som er registrert i ISI-databasen samt noen nasjonale og nordiske tidsskrift som har særlig strategisk betydning innenfor pedagogikk og utdanningsforskning. Begrunnelsen for denne metodiske inngangen til nordisk utdanningsforskning er at mandatet omtaler en mulighetsstudie som skal beskrive noen generelle trekk ved utdanningsforskningen. Vi tar ikke sikte på å beskrive et komplett bilde av nordisk utdanningsforskning, det er heller ikke mulig innenfor rammen av prosjektet. 
Nordisk ministerråd ønsker også en kartlegging av de ulike politiske og nasjonale initiativ i forhold til utdanningsforskningen. Her har NIFU STEP allerede god oversikt i enkelte av de nordiske land, og når det gjelder internasjonale trender. Denne delen av prosjektet inkluderer datainnsamlingsaktiviteter overfor nasjonale forskningsråd og myndigheter.

Vi vil også trekke veksler på referansegruppen som er oppnevnt, blant annet for å identifisere informanter som kan bidra med perspektiver på utdanningsforskningen i hvert av landene og for å identifisere nye initiativ på feltet (se kapittel 4 og 5). Nordisk ministerråd har ønsket at prosjektet også skal gjennomføre intervjuer med landenes forskningsbevilgende råd og myndigheter (forskningsråd og departementer), i tillegg til intervjuer med øvrige informanter (se Appendiks 2 for liste over informanter).

NIFU STEP har inngått et samarbeid med Technopolis i Stockholm (ved Lars Geschwind) der man vil se nærmere på forskningsinitiativ og den mer forskningspolitiske tekningen knyttet til dette feltet (se kap. 3). Det fokuseres på et utvalg eksisterende/gjennomførte forskningsinitiativ/programmer innen de nordiske land, der man analyserer hvilken formidlingsstrategi og formidlingspraksis som landene har brukt, og gjør en vurdering av hensiktsmessigheten og effekten av denne. Grunnlaget er dokumentasjon av ulike art, samt samtaler og intervjuer med aktuelle informanter angående nasjonalt initierte forskningssatsninger i de nordiske landene.

Dette vil utgjøre informasjonsgrunnlaget for mer nyanserte beskrivelser av utdanningsforskningen i hvert av landene i kapittel 4. Her vil vi prøve å fange opp eventuelle nasjonale særtrekk ved forskningsaktiviteten på området, involverte disipliner og institusjonelle kjennetegn, samt om det eksisterer nordiske fellesnevnere innenfor feltet hvor en mer samordnet nordisk innsats eventuelt kan tenkes. I tillegg til analysene i kapittel 2, vil denne beskrivelsen baseres på gjennomgangen av sentrale forskningsprogrammer og formidlingsinnsatsen i tilknytning til dette i kapittel 3. Kapittel 4 kan dessuten bygge på supplerende og utdypende informasjon fra de informantene fra hvert land som er valgt ut på grunnlag av forslag fra medlemmene i referansegruppen. I tillegg kan vi dra nytte av intervjuer med landenes forskningsbevilgende råd og myndigheter (forskningsråd og departementer) når det gjelder diskusjon av det nordiske utdanningsforskningsfeltet og identifisering av mulighetene for nordiske initiativ.

Basert på disse kildene har denne mulighetsstudien samlet sett følgende elementer:

- Bibliometrisk identifisering av noen aktive forskere/miljøer som har publisert i aktuelle utdanningsforskningstidsskrift basert på ISI- 
databasen, samt sentrale publiseringskanaler innenfor utdanningsforskning i Norden i perioden 2005-2008. Dette er en tilstrekkelig tidsdimensjon for å fange opp noen aktive forskere og deres miljøer, og som kan bidra til å belyse trekk ved publiseringsmønstre innenfor nordisk utdanningsforskning (se kap. 2 og Appendiks 3).

- I tillegg identifiseres mønstre i publiseringsaktiviteten innenfor noen sentrale tidsskrift på forskningsfeltet i Norden, for å bringe inn publisering/forskning som ikke dekkes av ISI-databasen (se kap. 2 og Appendiks 4).

- Gjennom identifisering av sentrale forskningsprogrammer i Norden i perioden 2004-2009, samt deres formidlingsstrategi vil strukturelle forhold for utdanningsforskningen og likheter/forskjeller de nordiske landene imellom bli belyst (se kap. 3).

- En foreløpig oppsummering av feltet er beskrevet i en midtveisrapport og diskutert med referansegruppen som er oppnevnt for prosjektet. På grunnlag av dette er det gjennomført en kartlegging av aktivitet/profil i de nordiske landene (se kap. 4) basert på intervjuer med sentrale informanter innenfor utdanningsforskningsfeltet i hvert av landene.

Basert på disse delanalysene, vil NIFU STEP og Technopolis diskutere hvilke alternativer som eventuelt eksisterer for en nordisk satsning innen utdanningsforskning og formidling (se kap. 5). Referansegruppen for prosjektet har en viktig rolle både som valideringsinstans og diskusjonspartner gjennom hele prosjektet. Det redegjøres nærmere for metode og gjennomføring av hver delanalyse i de påfølgende kapitler.

\subsubsection{Tidsplan}

Prosjektet er gjennomført i tett dialog med oppdragsgiver og referansegruppe, og har hatt følgende tidsramme:

\begin{tabular}{lll}
\hline 2009 & & \\
\hline & & \\
& 30. april & Referansegruppemøte i NMR og prosjektoppstart \\
17. august & Midtveisrapport leveres \\
& NIFUSTEP og Technopolis møter NMR og referansegruppen og disku- \\
& terer foreløpige funn \\
& Ordførerkonferanse på Island \\
& 23. september & NIFUSTEP og Technopolis presenterer midtveisrapporten \\
& 24. november & Sluttrapport leveres \\
11. januar & Presentasjon av rapporten i EK-U \\
& NIFUSTEP \\
& Februar/mars & Trykking og publisering av rapport v/NMR. \\
\hline
\end{tabular}

\subsubsection{Rapportens gang}

Rapporten følger den struktur som data og metodekapittelet har skissert. Dette innebærer at kapittel 2 formidler kartleggingen av nordisk utdanningsforskning basert på et utvalg av den publisering som finner sted i 
både ISI-indekserte og ikke ISI-indekserte tidsskrift. Her vil identifiseres noen mønstre innenfor utdanningsforskningen i hvert av landene, noen aktive miljøer og til en viss grad også temaer som forskningen omhandler. I kapittel 3 følger en gjennomgang av overordnede forskningsinitiativ - med spesiell vekt på nasjonale forskningsprogrammer. Her vil analysen avdekke både den forskningspolitiske tenkningen rundt utdanningsforskning som forskningsfelt, eventuelle forskningspolitiske prioriteringer, samt formidlingsstrategiene som er valgt. I kapittel 4 gjøres det, basert på disse kapitlene samt intervjuer med sentrale informanter i hvert land, en analyse av hvert av de nordiske land som inngår i dette prosjektet, der man søker å identifisere forskningens faglige innretning, samt sammenhengen mellom forskningsinnretning og de nasjonale satsningene på feltet. I kapittel 5 oppsummeres sentrale funn, og anbefalinger knyttet til nordiske satsninger på feltet konkretiseres. 



\section{Publiseringsmønstre innenfor nordisk utdanningsforskning}

\subsection{Identifisering av publiseringsmønstre}

Mønstre for publisering av resultater av forskningen uttrykker hvilke forskningssamtaler som oppfattes som viktige og relevante å delta i, både lokalt, nasjonalt og internasjonalt. Forskeres samtaler om forskningens relevans og kvalitet foregår blant annet gjennom publisering i tidsskrift, serier, bokforlag el. med rutiner for fagfellevurdering. Publisering internasjonalt representerer en viktig del av forskersamfunnets kvalitetssikring. I tillegg foregår forskningsformidlingen gjennom mange andre kanaler, som undervisning samt annen mer allmennrettet formidling.

Når det gjelder forskningsformidling viser tidligere kartlegginger og evalueringer at utdanningsforskningen i Sverige og Norge er bredt og sammensatt felt med stor publiserings- og formidlingsaktivitet, og ofte uten klare grenser mellom disse kommunikasjonsformene (Borgen m.fl. 2007, NFR 2005, Sivertsen 2007, Gunnes 2009). Utdanningssystemene i hvert av landene har nasjonale særpreg, og tradisjonelt har utdanningsforskerne tatt et stort ansvar for formidling inn mot sektoren, både overfor politikken, praksisfeltet og mer allmennrettet. I Sverige foregår en stor andel av forskningspubliseringen i tidsskrift og serier utgitt av lærestedene. En gjennomgang av publiserings- og formidlingsmønstre innenfor norsk utdanningsforskning fra 2007 viser stor samfunnskontakt men forholdsvis lite kommunikasjon med fagfeller gjennom fagfellevurderte publiseringskanaler (Borgen m.fl. 2007, Sivertsen 2007). Innenfor utdanningsforskningen i Norge er det dessuten en tradisjon for utstrakt praksisrettet og allmennrettet formidling, i tillegg til lærebokproduksjon. Dette kan tyde på at forskningens frihet i valg av forskningstema står sterkt, og at relevansvurderingene i stor grad ligger hos den enkelte forsker (Borgen m. fl. 2007).

Bibliometriske analyser viser at publiseringsmønstre varierer fra fag til fag, men ikke så mye fra land til land (Sivertsen 2007:7). Det er derfor rimelig å anta at de trekkene som er identifisert i svensk og norsk utdanningsforskning også kan gjenkjennes i de øvrige nordiske landene og selvstyrte områder som inngår i dette prosjektet. At lokale kanaler har stor betydning innenfor utdanningsforskningen, det vil si publikasjonene utkommer ved lærestedene, ofte forfatternes egen institusjon, betyr også at det er uklare grenser mellom publisering og formidling. I Norge er det utviklet et system for innsamling og strukturering av publikasjonsdata fra forskningen. I dette systemet regnes lokale kanaler (artikler i tidsskrift og 
serier utgitt av lærestedene) primært som forskningsformidling til brukere og myndigheter. Denne aktiviteten er det ikke meningen å dekke med den norske forskningsindikatoren som primært vektlegger at publisering som et minimum - bør skje i fagfellevurderte kanaler på nasjonalt nivå. For å dokumentere utdanningsvitenskapens samfunnsmessige betydning, er den utstrakte publiserings- og formidlingsaktiviteten nasjonalt og lokalt svært viktig, men en slik kartlegging av formidlingsaktiviteten innen utdanningsforskning i de nordiske land er som før nevnt ikke mulig innenfor prosjektrammen.

Vi har som nevnt tatt utgangspunkt i hva man internasjonalt vil kunne finne om man ønsker å bli bedre kjent med nordisk utdanningsforskning. Web of Science (Thomson ISI) sammenligner forskningen internasjonalt, primært naturvitenskap og medisin, mens humaniora og samfunnsvitenskapelig generelt, og pedagogikk og utdanningsvitenskap spesielt - er svakere dekket. For å undersøke publiseringsmønstre i utdanningsvitenskap er ISI-data til begrenset hjelp, selv om ISI også omfatter tidsskrift på nordiske språk. I pilotprosjektet på bibliometriske data fra bevilgede prosjekter innenfor Vetenskapsrådets utbildningsvetenskapliga kommitté (UVK), fant Sivertsen (2007:4) at 52 prosent av de vitenskapelige tidsskriftsartiklene i UVK's demo-database var tidsskrifter som dekkes av ISI. Når vi likevel har vi valgt å starte kartleggingen av nordisk utdanningsforskning gjennom ISI er dette begrunnet med at denne databasen sannsynligvis fungerer som en av flere innganger til nordisk utdanningsforskning for forskere fra andre land fordi den er enkel å finne fram i. Nordiske forskere som publiserer i disse tidsskriftene kan være særlig interessert $\mathrm{i}$ å nå ut til et større publikum, og dermed kan vi danne et forholdsvis snevert, men tydelig mønster av nordisk utdanningsforskning som kan være utgangspunkt for videre analyser. Siden publiseringsmønstre varierer fra fag til fag men ikke så mye fra land til land, vil mønstre som kommer frem gjennom denne metoden kunne beskrive noen trekk som senere kan kontrolleres gjennom søk i andre tidsskriftsdatabaser.

\subsection{Noen sentrale kjennetegn ved nordisk utdanningsforskning som publiseres internasjonalt}

Som nevnt har vi benyttet ISI-databasen for å identifisere forskningsintensive nordiske utdanningsforskningsmiljøer. Tanken har vært at aktive miljøer over tid også vil publisere sine forskningsresultater for et internasjonalt publikum. Med utgangspunkt i perioden 2005-2008 er alle artikler i ISI-databasen med en nordisk adresse identifisert. Videre har den organisatoriske tilhørighet i 71 ISI indekserte vitenskapelige tidsskrift blitt analysert (se Appendiks 3). Kun artikler med minst en nordisk adresse er inkludert. Siden mange artikler har flere forfattere er det ikke 
mulig å koble dem alle på en tilfredsstillende måte, og dette er en av begrensningene ved metoden.

Siden en av hensiktene med denne analysen er å finne ut hvilke forskningsmiljøer forskerne er tilknyttet, har vi videre identifisert førsteforfattere i utvalgte tidsskrifter og internett-addressene til deres miljøer manuelt. Her er kun fagfellebedømte artikler telt med. Dette betyr at for eksempel proceedings papers og artikler som er kategorisert som editorial material etc. med nordisk forfatter, er utelukket (se Appendiks 4). Denne manuelle identifiseringen har også gjort det mulig å registrere antall medforfattere med adresse i Norden og i land utenfor Norden, noe som bidrar til å danne et bilde av hyppigheten av internasjonalt samarbeid om publisering. Et viktig problem her er at flere nordiske tidsskifter ikke gir gratis informasjon på sine internettsider om miljøtilhørighet for forfatterne. Dette gjelder for eksempel Dansk Pædagogisk Tidsskrift, Norsk Pedagogisk tidsskrift, samt Nordisk pedagogik Nordic Studies in Education, og dette er en av begrensningene ved metoden. Det er også en begrensning ved metoden at når søket begrenses til perioden 2005-2008 viser det seg at årets siste utgave av journalen ikke alltid kommer med i søkeresultatet, noe som fører til at noen forfattere og miljøer som har publisert nylig ikke blir telt med.

Studien av norsk utdanningsforskning (Borgen m.fl. 2007) viste at flere engelskspråklige tidsskifter utenfor ISI-databasen var sentrale publiseringskanaler for norsk utdanningsforskning. Scandinavian Journal of Educational Research var det mest frekvente tidsskriftet blant de engelskspråklige hvor norske utdanningsforskere publiserte i 2005 og 2006 i følge rapporten. ISI-databasen får etter hvert får større bredde, og for eksempel kom Scandinavian Journal of Educational Research inn i basen i 2007. Vi har derfor tatt med dette tidsskriftet samt European Educational Research Journal i gjennomgangen av artikler med førsteforfatter med adresse ved en nordisk institusjon i perioden 2005-2008. Argumentet for dette er da å fange opp forskere som ikke har publisert i ISIindekserte tidsskrift.

\subsubsection{Både bredde og konsentrasjon}

Totalt hadde 71 tidsskrifter i ISI-databasen trykket minst ett nordisk bidrag i denne perioden, og det totale antallet bidrag som ble identifisert var 427 (se Appendiks 3 identifisert under søkeordet «education» for en detaljert oversikt). Basert på dette materialet er det mulig å antyde noen sentrale kjennetegn ved forskningsintensive nordiske utdanningsforskningsmiljøer.

For det første kan det argumenteres for at spredningen av forskningen på hele 71 ulike tidsskrift som dekker svært ulike spesialiseringer innenfor utdanningsforskningsfeltet gir en sterk indikasjon på at nordisk utdanningsforskning er svært mangfoldig og involverer ulike disipliner og fagmiljøer. Dette gjelder både i forhold til at man synes å publisere både i 
nisjetidskrift og i mer breddetidsskrift, men også at adressene på forfatterne gir sterke indikasjoner på et stort mangfold når det gjelder hvilke disipliner og fagfelt som er involvert i utdanningsforskningen. I tillegg til de rene pedagogikkmiljøene som man forventer skal være representert, finner man også forfattere med tilknytning til humanistiske, medisinske, samfunnsvitenskaplige og naturvitenskaplige fagfelt og miljøer.

For det andre er spredningen i antall tidsskrift likevel ikke ensbetydende med mangel på faglig konsentrasjon. Av de 71 tidsskriftene som har nordiske bidrag har 14 av disse i perioden 2005 - 2008 trykket mer enn 10 bidrag med nordisk forfatteradresse (se tabell 2.1). Titlene på disse tidsskriftene kan her være indikasjoner på en sterk spesialisering, og tre områder synes å være sterkt fremme. Et slikt område er studier av ny teknologi i læringssammenheng, herunder bruk av IKT. Flere av tidsskriftene i ISI-databasen har en spesiell profil innenfor dette området, og et tidsskrift som f eks Computers \& Education har i perioden 2005 - 2008 trykket hele 20 bidrag fra nordiske miljøer. Et annet område som peker seg ut er studier av høyere utdanning hvor to tidsskrifter - Higher Education og Studies in Higher Education har trykket respektive 34 og 23 bidrag med nordiske forfattere. Et siste område som peker seg spesielt ut er det man kan kalle lærings- og curriculumstudier mer allment hvor tidsskrifter som Curriculum Studies og Learning and Instruction har henholdsvis 12 og 13 bidrag med nordiske forfattere.

Ved siden av disse tre hovedområdene som peker seg ut, er en rekke mindre områder hvor det er også mulig å identifisere tendenser til konsentrasjon. Dette er områdene Science Education, Health Education, Gender Education, Moral and Philosophical Education og Physical/Sport Education - der nettopp tidsskriftstitlene gir antydninger om spesialiseringsfeltet.

Tabell 2.1 ISI-indekserte tidsskrift med mer enn 10 bidrag fra nordiske forfattere i perioden 2005-2008

\begin{tabular}{lrrr}
\hline Tittel på tidsskrift & $\begin{array}{r}\text { Antall nordiske } \\
\text { bidrag inkl artikler }\end{array}$ & $\begin{array}{r}\text { Antall nordiske } \\
\text { artikler }\end{array}$ & $\begin{array}{r}\text { Alle artikler/alle } \\
\text { land i perioden }\end{array}$ \\
\hline Higher Education & 34 & 31 & 262 \\
Health Education Research & 26 & 25 & 328 \\
Studies In Higher Education & 23 & 20 & 160 \\
Computers \& Education & 20 & 18 & 410 \\
Educational Technology \& Society & 18 & 18 & 257 \\
International Journal Of Science Education & 17 & 17 & 316 \\
British Journal Of Educational Technology & 15 & 7 & 301 \\
Teaching And Teacher Education & 14 & 14 & 388 \\
Learning And Instruction & 13 & 13 & 164 \\
Journal Of Curriculum Studies & 12 & 7 & 102 \\
Journal Of Computer Assisted Learning & 10 & 10 & 148 \\
Journal Of Moral Education & 10 & 8 & 111 \\
Minerva & 10 & 2 & 42 \\
Paedagogica Historica & 10 & & 53 \\
\hline
\end{tabular}

Som det fremgår av oversikten i tabell 2.1 er andelen nordiske artikler i de fleste av disse tidsskriftene lav i forhold til det samlede antall artikler i 
perioden. Det er imidlertid også slik at land med engelsk hovedspråk, slik som USA, England og Australia gjerne dominerer blant bidragsyterne, unntaket er innenfor IKT der asiatiske land har mange bidrag. Det fremgår også av tabellen at tidsskriftene har ulikheter når det gjelder andelen av fagfellevurderte artikler i forhold til andre typer bidrag. Dette betyr at i noen tidsskrifter, som Journal of Curriculum Studies og Paedagogica Historica, har nordiske utdanningsforskere ikke bare artikler, men også bidrag som er kategorisert som for eksempel proceedings papers, book reviews, editorial material. Disse bidragene kan være viktige faglig sett i forskersamfunnet, men har likevel en annen status enn fagfellevurderte artikler. Det er verd å bemerke at av 14 artikler i Teaching and Teacher Education er halvparten finske.

Man kan ut fra titlene på tidsskriftene også antyde at det kanskje er noen områder der nordiske forskere ikke har et spesielt tyngdepunkt $\mathrm{i}$ internasjonal utdanningsforskningssammenheng. Av områder som kan nevnes her er studier av ledelse og styring i utdanningssektoren, policystudier mer generelt, studier innen spesialpedagogikk, studier knyttet til mangfold/integrasjon og den flerkulturelle skolen, samt studier av utdanningsfeltet ut fra et økonomisk/effektivitetsperspektiv. Her skal det imidlertid sies at det er en stor mulighet for at enkelte av disse områdene i en viss grad kan være dekket av artikler som er trykket i mer generelle utdanningsforskningstidskrifter så som British Journal of Sociology of Education og Educational Research.

Et fjerde kjennetegn som dataene gir indikasjoner på, er at nordisk utdanningsforskning er preget av både bredde og konsentrasjon når det gjelder hvilke laresteder som er aktive (se tabell 2.2). Ser man på de læresteder som forfatterne kommer fra, synes det $\mathrm{f}$ eks å være tendenser til en viss grad av faglig konsentrasjon i både Danmark, Sverige, Finland og Norge. I Danmark utpeker f eks Aarhus Universitet seg som et lærested som publiserer mye på utdanningsforskningsfeltet. I Norge er universitetene i Oslo og Bergen hjemsted for mange forfattere. I Finland er universitetene i Helsinki, Turku og Jyväskylä også nevnt som adresse for mange forfattere, samt at man i Sverige ser at universitetene i Stockholm, Umeå og Uppsala har mange forfatteradresser. 
Tabell 2.2. Nordiske institusjoner med flest forfatteradresser i ISI-indekserte tidsskrift innen utdanningsforskningsfeltet 2005-2008

\begin{tabular}{llr}
\hline Land & Institusjon & Antall Bidrag \\
\hline Danmark & Aalborg Universitet & 5 \\
& Aarhus Universitet & 9 \\
& Københavns Universitet & 4 \\
Finland & Helsinki Universitet & 10 \\
& Joensuu Universitet & 6 \\
& Jyväskylä Universitet & 11 \\
Island & Turku Universitet & 8 \\
& Islands Universitet & 3 \\
Norge & Bergen Universitet & 7 \\
& Oslo Universitet & 9 \\
Sverige & Stockholms Universitet & 11 \\
& Umeå Universitet & 8 \\
& Uppsala Universitet & 5 \\
Færøyene & Ingen institusjoner med mer enn 1 oppføring & \\
\hline
\end{tabular}

Som nevnt innledningsvis og i avsnittet om data og metode, er ikke ISIpublisering nødvendigvis representativt for feltet utdanningsforskning. Man kan godt tenke seg at det er forskningsaktive miljøer som ikke publiserer internasjonalt - der man heller enten publiserer mer i nasjonale og nordiske evt andre tidsskrift som ikke indekseres av ISI, eller at man publiserer i andre kanaler man kan kalle «grå litteratur» i betydningen at den er lite synlig; konferansepapers, ulike rapporter og i form av formidling i ikke-fagfellevurderte kanaler (bøker, rapporter, etc). For å ta høyde for dette, har vi i tillegg til ISI-databasen også identifisert noen nasjonale og nordiske (og europeiske) tidsskrift innen utdanningsforskningsfeltet for å identifisere om det eventuelt kan være andre fagmiljøer som er aktive innen utdanningsforskning. Hovedtendensen her er imidlertid at de læresteder som utpekte seg som sentrale i ISI-databasen også er de som står oppført som hyppigste hjemsted for forfattere som publiserer i nasjonale/nordiske/europeiske tidsskrift (se Appendiks 4 for detaljert oversikt). Ut fra dette synes det som om det også er et kjennetegn ved nordisk utdanningsforskning at de miljøer som publiserer mye internasjonalt også publiserer mye i andre kanaler. Dette er for øvrig et kjennetegn som er gjeldende for en rekke andre fagfelt og disipliner.

Samtidig ser man også at det er mange læresteder som publiserer utdanningsforskning i mer varierende grad. I Sverige er det i perioden 2005 2008 hele 19 ulike læresteder og forskningsinstitutter som har publisert utdanningsforskning internasjonalt. I Norge er det ikke mindre enn 24 ulike læresteder og institutter som står oppført som hjemsted for forskningen. Også på Island og på Færøyene synes det å være spredning på hvilke læresteder og institusjoner som publiserer utdanningsforskning. Det er imidlertid også mulig at publiseringsmønstrene gjenspeiler andre forhold som ikke direkte handler om de enkelte miljøene, men som er relatert til mer strukturelle forhold når det gjelder UoH-sektoren i det enkelte land. Ser vi for 
eksempel på miljøadressene til førsteforfatterne til artiklene i Scandinavian Journal of Educational Research, er det 11 norske miljøadresser hvorav fem er universiteter og seks er høyskoler, mens alle de svenske og finske artiklene har universitetsadresser (se Appendiks 4). Slike strukturelle forhold vil kunne bli belyst i den kvalitative analysen i kapittel 4 .

\subsubsection{Samforfatterskap i Norden og internasjonalt}

Materialet viser at det er stort mangfold blant tidsskriftene nordiske utdanningsforskere publiserer i, og stort antall forskere som publiserer. De aller fleste forskerne står som førsteforfattere på én artikkel i løpet av perioden 2005-2008, det er færre forskere som står oppført som førsteforfattere på to artikler og svært få forfattere har tre artikler i perioden i de tidsskriftene vi har analysert.

Mange forfattere publiserer alene, og det er tydelige forskjeller mellom fagmiljøene. Årsakene til dette er det ikke mulig å ta stilling til. For eksempel kan det være at det er noen sterke enkeltforskere i miljøet, eller det være et tegn på at miljøet har mange ph.d.-kandidater som skriver artikler til sine avhandlinger. Blant artiklene med nordisk samforfatterskap har mer enn halvparten medforfattere lokalt eller nasjonalt. I tidsskriftene Science Education og Research in Science Education publiserer oftest to til seks nordiske forfattere sammen. Derimot er mønsteret i Scandinavian Journal of Educational Research at ca halvparten av forfatterne publiserer alene, mens det er få artikler der fire til fem forfattere publiserer sammen, og kun tre artikler der det er medforfattere utenfor Norden.

Til sammen gir dette grunnlag for å anta at det er en del samarbeid mellom forskere i Norden, men at det forholdsvis mange små (og individuelle eller lokale) forskningsprosjekter og få store og internasjonale prosjekter som ligger til grunn for de nordiske artiklene i disse tidsskriftene.

\subsection{Oppsummering}

I denne bibliometriske analysen er det gjort et strategisk utvalg av tidsskrifter under søkeordet education i ISI-databasen, for å identifisere publiseringsmønstre blant nordiske utdanningsforskere. Begrunnelsene er flere. Med utgangspunkt $\mathrm{i}$ at mandatet for denne mulighetsstudien går ut på å beskrive noen generelle trekk ved nordisk utdanningsforskning, har vi i dette kapitlet ikke tatt sikte på å beskrive et komplett bilde av publiseringen innenfor nordisk utdanningsforskning, dette er heller ikke mulig innenfor rammen av prosjektet. Vi har som før nevnt i stedet startet med å stille spørsmålet om hva man internasjonalt vil kunne finne om man på et generelt grunnlag ønsker å bli bedre kjent med nordisk utdanningsforskning, og i denne sammenhengen er søk i ISI Web of Science et internasjonalt hjelpemiddel. Det er selvsagt en 
del begrensninger ved denne metoden, blant annet kan vi ikke uten videre si noe om hva som ikke inngår i ISI-databasen.

Av begrensningene som vi imidlertid har observert er at det er ulik praksis angående registrering av forfatteradresser i tidsskriftene, blant annet i de nordiske tidsskriftene som henvender seg til et internasjonalt forskersamfunn. Dette kan være et hinder for at nordisk utdanningsforskning blir oppdaget utenfor Norden. Vi observerer også at nordiske forskere har andre typer publikasjoner enn fagfellebedømte artikler i disse tidsskiftene, og dette kan være viktige faglige bidrag selv om disse har en annen status.

Tematisk er det gjennomgående stor bredde, og samtidig ser vi konsentrasjon om noen områder. Dette kan selvsagt ha sammenheng med utvalget av tidsskrifter innenfor ISI-databasen. Imidlertid tyder forfatter-adressene på at det kanskje ikke behøver å være sammenheng mellom de sentrale forskningstema som nordiske utdanningsforskere synes å publisere i forhold til, og de mest aktive forskningsmiljøene (se tabell 2.1 og 2.2).

Et annet forhold som fremtrer i analysene over er tendensene til individualisert publisering som gjenspeiles i publiseringsmønstrene. Dette bidrar på den ene side til å svekke antagelsen om at miljøene har betydning for publisering. Det kan like gjerne være omvendt, at en viss type forskere samles i visse miljøer fordi det der er rom for deres individualitet og styrke. På den andre side kan det også være et uttrykk for at det er et stort antall unge ph.d.-studerende som publiserer artikler i internasjonale tidsskifter som ledd i arbeidet med sine avhandlinger, og da er det rimelig å anta at miljøet har en bestemt kvalitet som resulterer i produktive doktorander. Et tredje forhold som analysene viser er tendensene til at strukturen for UoH-sektoren slår inn på publiseringsmønstrene (se Appendiks 4 for detaljert oversikt). Dette kan indikere at spesialisering i mindre grad er resultat av systematisk miljøbygging, og like gjerne kan være et resultat av sterke individuelle interesser, eventuelt at noen forskere er særlig dyktige til å få tilgang på ressurser, for eksempel ekstern prosjektfinansiering. I og med at denne bibliometriske metoden ikke dekker hele bredden av nordisk utdanningsforskning, er det i tillegg klart at det kan finnes andre forskningsprofiler og miljøer som analysen ikke har fanget opp. Når det gjelder samforfatterskap nordisk og internasjonalt er det imidlertid mulig å anta at de bibliometriske analysene viser mønstre som også kan gjenfinnes om man ser på hele utdanningsforskningsfeltet. De neste kapitlene er derfor viktige bidrag for å kunne supplere bildet som denne bibliometriske analysen gir av nordisk utdanningsforskning. 


\section{Forskningsprogrammer i Norden i 2004-2009, samt deres formidlingsstrategi}

I detta kapitel ser vi närmare på sentrala riktade forskningssatsningar, t.ex. forskningsprogram, i de nordiska länderna som riktar sig särskilt mot utbildning. Genom att kartlägga sådana centrala initiativ för att öka kvantitet och kvalitet inom utbildningsforskningen, får vi en bild av det aktuella läget. Sammanställningen bygger på information från hemsidor, epostkorrespondens, intervjuer med forskare och tjänstemän samt tidigare rapporter. Den gör inte anspråk på att vara fullständig, men förhoppningen är att de största och mest väsentliga satsningarna har kommit med.

Som nämnts på andra håll i rapporten utgör dessa satsningar långtifrån hela bilden när det gäller vilken utbildningsforskning som faktiskt bedrivs. I flera länder är finansieringssystemet sådant att den mesta forskningen sker via de direkta statsanslagen för forskning, snarare än riktade satsningar som fås i konkurrens. Det finns därför inte anledning att utan vidare jämföra de olika ländernas riktade satsningar med varandra. Det säger givetvis inte heller något om kvaliteten i den forskning som sedan finansierats. Det viktigaste skälet för att se vilka finansieringssatsningar som har gjorts är att se på vilket sätt den nordiska nivån kan samspela med den nationella. Vad kan göras för att ge ytterligare stöd till den forskning som bedrivs om utbildning?

\subsection{Programsatsningarna 2004-2009}

\subsubsection{Danmark}

I den danska regeringens globaliseringsstrategi ingår ett strategiskt forskningsprogram om utbildningsvetenskap. Det avsätts totalt 60 miljoner DKR till utbildningsvetenskaplig forskning under åren 2008-2010. Forskningsprogrammet ska understödja de utbildningspolitiska målsättningarna i Danmark: att minst 95 procent av en årgång ska genomföra en «ungdomsuddannelse» och minst 50 procent av de unga ska ha en «videregående uddannelse». Ett annat mål är att utbildningarna ska motsvara arbetsmarknadens, samhällets och den enskildes behov. Därför ska utbildningarna hålla en hög kvalitet, även i ett internationellt perspektiv. Programmet har således en tydlig koppling till policy. Utgångspunkten är det låga antalet sökande till olika utbildningsnivåer i relation till utbudet 
av arbeten. Man konstaterar att efterfrågan överstiger utbudet när det gäller mellanlånga utbildningar på välfärdsområdet samt bl.a. tekniska och naturvetenskapliga utbildningar (professionsbachelor). Det finns således tomma platser vid lärosätena.

En viktig utgångspunkt har med kvaliteten att göra. Satsningarna har gjorts med hänvisning till de internationella mätningar som görs av skolelevers kunskaper, t.ex. PISA-undersökningen. De danska eleverna ligger t.ex. efter övriga nordiska länder när det gäller läsning (däremot bättre i matematik). En kritisk OECD-rapport från 2006 visade att forskningen var alltför fragmenterad men också i alltför liten utsträckning kvantitativt orienterad. Det handlar dock inte bara om studieresultaten utan också om de sociala aspekterna av utbildning.

Den danska Forsknings- og Innovationsstyrelsens bakgrundsrapport som refererats ovan kan sägas utgöra ett tydligt exempel på en tydlig beställning till forskningsutförarna att koncentrera sig på vissa problemområden framför andra. Sju områden pekas ut som mest intressanta för forskningsprogrammet. Därtill diskuteras i ett kapitel de metoder som bör användas inom forskningen: kontrollerade försök, gärna under en längre period, komparativa studier, kvasi-experimentell design och kvantitativa metoder uppmuntras. Det Strategiske Forskningsrådets Programkomite for Uddannelse og Kompetenceudvikling delar ut forskningsmedel inom temana:

- «Uddannelsesforskning» (33 miljoner dkr. 2008 och ca 35 miljoner dkr. 2010)

- «Professionsuddannelsernes arbejdsfelt» (11 miljoner dkr. årligen 2008-2010)

- «Hvad virker? - evidens i praksis» (med fokus på socialt arv) (ca 20 miljoner dkr. 2009) ${ }^{1}$

Dessutom blev det i 2008 fördelat ca 2,5 miljoner dkr. inom temat «Negativ social arv på de videregående uddannelser».

\subsubsection{Finland}

I Finland sker mycket av bevillningen av medel direkt till universiteten. En viss del går också till speciella miljöer som ansvarar för utbildningsforskning. Nedan nämns några av de program som har sjösatts med fokus på utbildning.

IKT och lärande har varit en viktig del i Finland ${ }^{2}$ som finansierats av bland annat Finlands Akademi och TEKES.

\footnotetext{
${ }^{1}$ http://www.fi.dk/soeg-stoette/opslag-stoettemuligheder/2009/strategisk-forskning-2009-uddannelse-og-kompetenceudvikling/

${ }^{2}$ Se sammanställning på t.ex. http://www.cicero.fi/sivut2/projects.html
} 
Finansieringen från Finlands Akademi är delvis i form av forskningsprogram där vissa områden prioriteras. Utgångspunkterna för Akademins forskningsprogram är att höja den vetenskapliga nivån inom det valda forskningsområdet, att utveckla en forskningsgren eller vetenskaplig disciplin och att skapa ny eller förstärka redan existerande vetenskaplig tradition och kompetens. Forskningsprogrammen främjar en tvärvetenskaplig infallsvinkel och utvecklar både det nationella och det internationella samarbetet mellan forskare, finansiärer och slutanvändare.

Det mest renodlade utbildningsvetenskapliga programmet som finansierats av Finlands Akademi går under namnet Life as Learning, LEARN:

\footnotetext{
Life as Learning (LEARN) is a multi-scientific national research programme on learning. The themes studied in the programme include developing teaching and learning in the school system, new challenges of learning in the working life, new forms of learning, and new teachership and teacher education.

The aim of the research programme is to:

encourage the development of a new research culture and new research partnerships and the creation of interdisciplinary and international research projects around the problems of learning; find a way of managing the challenges of lifelong and lifewide learning in order to avoid a new kind of exclusion: create a solid quality interdisciplinary research base for developing teaching and learning in different educational and working-life contexts; and anticipate future learning needs from the point of view of society, culture and the individual
}

Ytterligare ett utbildningsvetenskapligt program var igång under 1990talet: Impact of education.

Av Akademins årsredovisningar framgår dock att det finns program som tangerar utbildningsfrågor, genom dess fokus på välfärd och arbetsliv. Några exempel kan nämnas: forskningsprogrammet Barns välfärd och hälsa, forskningsprogrammet Arbetets och välfärdens framtid (WORK 2008-2011), forskningsprogrammet Ubicom och kommunikationens mångfald.

\subsubsection{Färöarna}

Färöarna har ett universitet med totalt 450 studenter. Även på Färöarna har det skett sammanslagningar då universitetet slogs år 2008 ihop med en vårdhögskola och en lärarhögskola.

Utbildningsforskning ligger under avdelningen Kultur vid Färöarnas forskningsråd. Det är intressant att notera att det är tydligt kopplat till det kulturella arvet: «Education at all levels is an important factor in cultural expression along with religion, which has had a profound influence on Faroese culture.» 


\subsubsection{Island}

På Island är utbildningsfrågorna högt prioriterade i det strategipapper som togs för perioden 2006-2009: «A coherent and continuous education from kindergarten to graduation from a university is essential for the development of a knowledge-based society» (Science and Technology Policy 2006-2009:7). Det finns ambitiösa framtidsplaner uttryckta för högre utbildning. Ett led i denna förändringsprocess är beslutet från det isländska parlamentet att slå ihop Islands universitet och Iceland University of Education, vilket blev ett faktum den 1 juli 2008. Syftet är att:

- säkra ett mer rörligt och flexibelt curriculum i utbildningsvetenskap (educational studies); öka möjligheterna för studenter

- förbättra undervisning och forskning I utbildningsvetenskap

- stärka stödsystemen för studenter och akademisk personal vid ett nytt och förbättrat universitet

- säkra att Island kan erbjuda utbildningsvetenskap som är jämförbar med det bästa I grannländerna

Några specifika forskningsprogram inriktade mot utbildningsvetenskap har vi däremot inte lyckats finna. Men när The Science and Technology Policy Council (STPC) 2008 utlyste medel för ett nytt forskningsprogram med «Centers of Excellence and Research Clusters», med finansiering upp till sju år, var utbildningsvetenskap ett av de på förhand föreslagna områdena:

Reinforcing research on education with a view to developing the educational system and make it respond more swiftly to increasing demands of knowledge, efficiency, creativity, initiative and flexibility.

Utbildning och skola är prioriterade områden på Island. Det beskrivs så här i ett dokument från forskningsministeriet (Challenges and Objectives in Science, Technological Development and Innovation, Draft, Autumn Meeting December 2007):

Research on education and school work:

The STPC gives priority to research into education and teaching. Modern education must transfer adequate knowledge to all citizens in order to meet increasing demands for reliable and complex know-how, creativity, flexibility, initiative and social inclusion. New technology and knowledge, emerging new culture and a favourable attitude towards the dynamic interplay between the development of new branches of industry and culture demands continuous renewal in teachers education and life long learning. This needs to be accompanied by multifaceted research on how to configure education for all young and old within or without school in order to meet high expectations.

Av de tre ansökningar som beviljades medel var dock inget utbildningsvetenskapligt. Det enda samhällsvetenskapliga forskningsklustret handlar 
om genus, jämställdhets- och mångfaldsfrågor (Center of Excellence in Gender, Equality and Diversity Research).

\subsubsection{Norge}

Norges forskningsråd har under den här undersökta perioden finansierat flera större program för utbildningsforskning. Redan 1996 startade dock programmet Kompetanse, utdanning, verdiskapning (KUV), med en årlig budget på 11 miljoner NOK. Programmet omfattade alla utbildningsnivåer samt lärande i arbetslivet. 36 projekt blev beviljade fram till 2002 då programmet avslutades. 19 projekt gick till institutsektorn medan 18 projekt gick till UoH-sektorn. Projektportföljen har tonvikt på studier av arbetsliv/livslångt lärande (18). Sex rörde högre utbildning/övergången till arbetsliv, ett statlig styrning av utbildning, tre gymnasiet (vidaregående skole), fyra grundskolan, två upplärning/skola generellt och ett inom kön och utbildning generellt.

När KUV avslutades sjösattes ett nytt forskningsprogram vid Forskningsrådet: Kunnskap, utdanning og laering (KUL). Det pågick mellan 2003 och 2007 med en samlad budgetram på 85,5 miljoner NOK, alltså avsevärt större än KUV. Det var dock vetenskapligt snävare med vissa öronmärkningar: 13 miljoner var avsedda för utvärdering av kvalitetsreformen och 25 miljoner till IKT och lärande. Två av projekten gick till institut medan 12 projekt gick till UoH-sektorn. Även inom detta program har samtliga nivåer varit föremål för studier: två projekt rörde statlig styrning av utbildning, två högre utbildning/arbetsliv, sex högre utbildning, tre grundskolan och ett projekt som rörde förhållandet hem och skola.

Programmet Praksisrettet FoU for barnehage, grunnopplæring og lærarutdanning skapades 2006 på initiativ av Kunnskapsdepartementet genom Forskningsrådet. Programmet pågår till år 2010 och den finansiella ramen är 154 miljoner NOK. Av dessa är 92 miljoner öronmärkta för grundskolan (2005-2008), 62 miljoner för förskolan och 10 miljoner för barn med funktionshinder (2006-2009). Vid de årliga utdelningarna av medel har vissa områden uttryckligen prioriterats inom dessa öronmärkta fält.

Ett annat pågående program är Utdanning 2020, som även det är ett initiativ från Kunnskapsdepartementet via Norges Forskningsråd. Det är beviljat 19 miljoner NOK för år 2009 och 24 miljoner årligen. Syftet med programmet är stärka utbildningsforskningen genom att främja forskning på hög vetenskaplig nivå och att stärka kunskapsunderlaget för politikutformning, förvaltning, professionsutbildning och professionsutövning. Flera ämnen och forskningsmiljöer ska stimuleras till att forska på problemställningar knutna till utbildningssektorn och till gränsområdena mot andra sektorer. Programmet öppnar för projekt inom följande fyra brett upplagda teman: 
- Utbildningens mål, innehåll, undervisning och arbetssätt

- Bedömningsformer, lärandeprocesser och lärandeutbyte i utbildningarna

- Styrning, ledning och organisering av utbildnings- och forskningsinstitutioner

- Utbildning och samhälle

Programmet pågår under perioden 2009-2018. Mycket av den forskning som initierats brottas med relationen mellan det praxisorienterade, problemlösningsinriktade och det andra genomgående kravet, nämligen vetenskapligt hög kvalitet, i en internationell jämförelse och i förhållande till andra närliggande vetenskapliga fält, inte minst det humanistisksamhällsvetenskapliga. Det illustreras väl av programtexten om det norska Utdanning 2020. Där finns åtta mål uttryckta: hög vetenskaplig kvalitet, hög praxis- och policyrelevans, stärka forskarrekryteringen, öka andel forskare med toppkompetens, stärka utbildningsforskningen som flervetenskapligt forskningsområde, stärka nationellt samarbete och arbetsfördelning, stärka internationellt samarbete och god kommunikation med programmets målgrupper.

\subsubsection{Sverige}

I Sverige är sedan år 2001 en utbildningsvetenskaplig kommitté (UVK) verksam vid Vetenskapsrådet (VR). Den bildades mot bakgrund av flera utredningar av lärarutbildningen och mandatet konkretiserades i propositionen Forskning och förnyelse. UVK är tidsbegränsad, men arbetar för att permanentas och göras till ett forskningsråd. Efter den första perioden 2001-2003 har verksamheten fortsatt och är fortfarande igång. Utbildningsvetenskap handlar om forskning om lärande, kunskapsbildning, utbildning och undervisning. UVK stödjer forskning om bland annat utbildningssystemets sociala, ekonomiska och politiska villkor, lärande, kunskapsbildning och kunskapsanvändning samt vägar till att öka mångfalden inom utbildning och undervisning (www.vr.se). Utbildningsvetenskapliga kommittén ger för närvarande bidrag till följande:

- Projektbidrag

- Planeringsbidrag

- Nätverk

- Forskarskolor

- Anställning som forskarassistent

- Gästforskare

- Konferenser

- Postdoktorsstipendium

- Bidrag till anställning som postdok i Sverige

- Bidrag för språkgranskning 
På grundval av de ansökningar som kom in under de första åren 20012004 gjordes en indelning i åtta områden år 2004/2005:

- Utbildningshistoria (t.ex. ämnesutveckling inom olika utbildningssystem)

- Utbildningssystem (t.ex. betygs- och urvalssystem, läroplansteorier, styrning och ledning, utbildningsekonomi, utbildningspolitik/policy)

- Värdefrågor (t.ex. demokrati, etik- och moralfrågor, pedagogisk filosofi)

- Individens lärande (t.ex. kunskapsutveckling, IKT pedagogisk psykologi och utvecklingspsykologi med fokus på individen)

- Grupprocesser (t.ex. kunskapsutveckling, IKT, pedagogisk psykologi, utvecklingspsykologi och sociologi med fokus på gruppen)

- Didaktik (såväl allmän som ämnesspecifik frågeställning inklusive specialpedagogik)

- Professioner (t.ex. lärares arbete och yrkesidentitet, lärarutbildning, skolledares arbete, karriärval och vägledning)

- Effektstudier (t.ex. reformers effekter, produktivitet, effektivitet)

Forskningen som finansieras är både tvär- och mångvetenskaplig. Merparten av ansökningarna till UVK är inlämnade av flera forskare. Dessa härrör ofta från olika discipliner som gått ihop om ett mångvetenskapligt projekt. Det är den vanligaste formen. Det finns också exempel på tvärvetenskapliga projekt där forskningen överskrider etablerade kunskaps- och organisationsgränser och integrationen sker vid t.ex. problemdefinitionen.

Även om UVK har en starkt dominerande ställning för utbildningsforskningsfinansieringen i Sverige finns ett antal andra initiativ. Exempelvis har KK-stiftelsen (www.kks.se) satsat på IKT i skolan, bland annat som initiativtagare till forskningsprogrammet LearnIT. Syftet var att på lång sikt bygga upp kunskap om lärande och IT i arbetsliv och skola. Inom LearnIT bedrivs forskning om hur IT påverkar lärande, kunskapsbildning och utbildning på både samhälls- organisations- och individnivå. LearnIT:s forskningsprojekt avslutades 2007. KK-stiftelsen satsade 100 miljoner på att stärka IT i lärarut-bildningen. Det är den största satsning på IT i skola och utbildning som gjorts sedan statens miljardprojekt IT i Skolan (ITiS) i slutet av 90-talet. Satsningen genomfördes i samarbete med lärarutbildningar, kommuner och näringsliv. Projektet motfinansierades av parterna med samma summa som beviljas av KK-stiftelsen.

UVK finansierade tillsammans med Knut och Alice Wallenbergs stiftelse och Riksbankens Jubileumsfond det mångvetenskapliga programmet Lärande och minne hos barn och ungdomar. Fyra forskningsprogram finansieras inom detta område. Den totala finansieringsvolymen var 72 mkr för en period av fem år. Syftet med satsningen är att fördjupa kunskaperna om hur barn och ungdomarna lär sig, hur de motiveras, hur de skapar begrepp och hur deras minne fungerar. Meningen är också att 
kunskaperna skall användas för att skapa bättre villkor för lärande på daghem, förskolor, skolor och universitet.

Forskningsområdet definieras i tre huvudtitlar: Emotion och motivation, Begreppsbildning och begreppsutveckling, Interaktiva lärandeprocesser, Sammantaget görs stora satsningar på utbildningsforskning i Sverige, med UVK som dominerande aktör.

\subsection{Förmedlingsstrategier i satsningarna}

En del av uppdraget har varit att se närmare på de forskningsförmedlingsstrategier som finns uttryckta i de riktade satsningarna. Förväntningarna på resultat från utbildningsforskning är stora, och intressenterna är många. I likhet med vissa andra vetenskapliga områden, t.ex. vård, finns förväntningar på att både publicera i vetenskapliga tidskrifter och att förmedla och sprida kunskap till en bredare publik. Det finns en tydlig önskan om en ökad tillämpning av forskningsbaserad kunskap. Av den anledningen behöver forskningsresultaten spridas och förmedlas. Resultaten av forskningen och hur de presenteras är av stor betydelse för kapaciteten att förändra. För utbildningsområdet är dessa krav höga, men också differentierade. Det handlar om att lösa problem som redan är kända men det handlar också om att utföra s.k. grundforskning av mer teoretisk art, där de kortsiktiga resultaten och effekterna kan vara svåra att identifiera och mäta (se även Hansen \& Lindblad 2009).

I flera av de kartlagda forskningssatsningarna finns uttryckta förmedlingsstrategier för de deltagande forskarna. Ett urval av strategier behandlas i det följande.

Det svenska UVK har utvecklat nätverk för kunskapsspridning via olika publikationer (forskningsöversikter, redovisning av avslutade forskningsprojekt m.m.) seminarier och förmedling via portalen www.forskning.se. Ett intressant exempel är den årliga konferensen Resultatdialog till vilken forskare som fått medel av UVK skriver en populärvetenskaplig rapport och deltar vid ett seminarium vid konferensen. Konferensen är ambulerande, den anordnas av olika lärosäten, närmare bestämt det regionala utvecklingscentret vid lärosätet.

De strategiska satsningarna som görs av Finlands Akademi innehåller också en del intressanta innslag rettet mot forskarsamfunnet. Inom forskningsprogrammen ordnas olika forskarworkshops, seminarier och vetenskapsfrukostar kring programmens teman. Inom beredningen av forskningsprogrammet Barns och ungdomars välfärd och hälsa ordnades t.ex. våren 2008 en öppen forskarverkstad i syfte att precisera programmets innehållsliga frågeställningar. Verkstaden samlade 140 deltagare.

Programmet Utdanning 2020, finansierat av Norges Forskningsråd, har som mål att satsningen ska ha en «offensiv och nyskapende strategi for kunnskapsdeling of formidling som både retter seg mot fagfeller og 
brukerne i sektoren» (se Programnotat s. 21). När det gäller den vetenskapliga förmedlingen uppmuntras publicering i internationella tidskrifter, böcker på internationella förlag samt paper vid internationella konferenser. Samtidigt konstateras att resultaten i alltför liten utsträckning påverkar praktikfältet. Det kan, som det diskuteras i utlysningstexten, både ha med publiceringsstrategierna inte är optimala och att forskningens problemställningar upplevs ligga alltför långt från praktiken. För att komma till rätta med detta upplevda missförhållande har programmet skrivit in tydliga incitament för forskarna att även ägna sig åt utövare och utbildare inom professionen. I de kvantitativa resultatmålen räknas således inte bara antal vetenskapliga publikationer utan även medial medverkan, seminarier och populärvetenskaplig publicering.

\subsection{Sammanfattande slutsatser}

Det första vi kan konstatera i genomgången av riktade satsningar är att utbildningsfrågor blivit allt viktigare för de nordiska länderna. Genom den globala konkurrensen om kunskap, arbeten och kvalificerad arbetskraft, har utbildningen hamnat högre på den politiska dagordningen. Utbildningsforskningen i de nordiska länderna representerar en väsentlig bredd när det gäller vilken typ av forskning som bedrivs och efterlyses genom riktade satsningar. Här finns hela skalan av grundforskning, tillämpad forskning och praxisorienterad forskning, för att välja några av de begrepp som används. I programmen finns också andra typer av kunskapsproduktion, som utvärderingar, reformuppföljningar och utredningsuppdrag.

Som en följd av det stora politiska intresset finns också förväntningar på att forskningen ska bidra till att lösa konkreta problem. Om det på ett högre plan handlar om den globala konkurrensen, är det påfallande likartade problem som ska lösas i de nordiska länderna. Exempel på sådana utmaningar är avhopp och studieavbrott, minskande andel studerande på olika nivåer (ibland med inriktning på kön), sämre resultat i internationella mätningar och prov. En skillnad gentemot andra länder är att Norge har satsat mest av de nordiska länderna på högre utbildning.

En del av forskningsfinansieringen har också varit inriktad på att fungera som kompetensutveckling för lärarutbildare. Synen på forskarutbildning och forskning som personlig meritering snarare än som kunskapsproduktion och -förmedling utgör ett spänningsförhållandena i de olika länderna, inte minst när det gäller vilka kvalitetskrav som kan ställas, och ställs, på forskningen.

Ett genomgående drag i satsningarna är önskemålen om tvär- eller mångvetenskapliga forskningsprojekt. Tvär- och mångvetenskapligheten inom fältet ser dock mycket olika i de olika länderna. Utan att gå in på detaljer kan man först konstatera att utbildningsvetenskap eller utbild- 
ningsforskning betyder olika saker i olika länder, det är inte heller etablerat som begrepp i alla länder. Disciplinen pedagogik (eng. education) är den term som används företrädesvis i vissa länder. Även det ämnet har dock blivit allt bredare under årens lopp. Att programmen är mång- eller tvärvetenskapliga har flera förklaringar. För det första kan man konstatera att många praxisorienterade program kräver lösningar som inte ett enda ämne kan leverera. Det räcker inte med att forskare inom en enda samhällsvetenskaplig disciplin, hur bred den än är, står för lösningarna på problemet. Frågeställningarna är således till sin natur tvär- eller mångvetenskapliga. För det andra innehåller fältet även forskare som inte är samhällsvetare i allmänhet eller pedagoger i synnerhet. Den ämnesdidaktiska forskningen exempelvis sträcker sig över samtliga ämnesområden.

Forskningsförmedlingen är av avgörande betydelse för resultatens användning. Flera av de nämnda satsningarna ovan har klart uttryckta, höga krav på både vetenskaplig publicering, helst internationell, men också mål att sprida resultaten till en vidare publik. Det finns förväntningar på att forskarna inom programmet ska kommunicera, både muntligt och skriftligt, till en mängd tänkta mottagare, inklusive lärare, tjänstemän och politiker. Man kan säga, som en försiktig generell slutsats, att det finns fler krav, riktlinjer och önskemål som riktas mot forskarna än det finns intressanta initiativ som görs av finansiärerna. Några intressanta nämns ovan, men när det gäller hur finansiärerna kan bidra till en ökad spridning av kunskapen finns troligen mer att göra. 


\section{Kartlegging av nordisk utdanningsforskning}

Denne kartleggingen av aktivitet/profil på sentrale utdanningsforskningsmiljøer i Norden er basert på intervjuer med sentrale informanter innenfor utdanningsforskningsfeltet i hvert av de nordiske landene (se informantliste i Appendiks 2). Informantene er plukket ut av landenes respektive medlemmer i referansegruppen. Sentrale tema for intervjuene har vært:

- Historikk

- Politikkutforming

- Ressursinnsats til forskning

- Institusjonelle rammer/personer

- Innhold i forskningen (tematisk innretning etc.)

- Resultat av forskningen (publisering, formidling)

- Nordisk styrke og nordisk profil

Under presenteres sentrale trekk ved utdanningsforskningen i hvert av landene som inngår i dette prosjektet i alfabetisk rekkefølge.

\subsection{Utdanningsforskning i Danmark}

\subsubsection{Historikk}

Utdanningsforskningen i Danmark bygger på behovet for lærerutdanning for gymnaset og for etter- og videreutdanning for lærere. Københavns Universitet fikk en professor i pedagogikk på midten av 1950-tallet. På 1950 - og 60-tallet var dessuten Socialforskningsinstituttet aktiv innenfor sosiologisk (kvantitativ) utdanningsforskning. Etableringen av de nye universitetene på begynnelsen av 1970-tallet kom til å bli starten på en ny bølge av mer tverrdisiplinær og problemorientert utdanningsforskning koblet til sektorpolitikkens kunnskapsbehov i Danmark.

\subsubsection{Politikk og utdanningsforskning}

Politikkutformingen i tilknytning til utdanningsreformene i grunnopplæringen har foregått i tett tilknytning til lærerutdanning og praksisfelt, og med Danmarks Lærerhøjskole (fra 2007 Danmarks Pedagogiske Universitetsskole (DPU) Aarhus Universitet) som sentralt miljø. De siste ti årene 
har utdanningsforskningen vært preget av strategisk politikkutforming i Undervisningsministeriet, noe som blant annet har sammenheng med OECD-evalueringen av dansk utdanningsforskning i 2004 og, ikke minst, resultatene fra PISA- studiene, som viste middels prestasjoner i grunnopplæringen. Mens utviklingsinitiativene innenfor utdanningsfeltet tidligere kom nedenfra gjennom forsøksvirksomhet lokalt, er mye av aktiviteten nå initiert ovenfra gjennom etableringen av nye sentre og institusjoner.

Ressursinnsatsen til forskning har i dag tre hovedkilder. For det første grunnbevilgninger som gir universitetene rimelig stor frihet til å underlegge forskningen egne strategiske overveielser. Dernest forskningsrådssystemet som nylig ble delt opp i det frie og det strategiske forskningsråd, og der utdanningsforskning som tverrfaglig og flerfaglig felt får penger fra begge kilder. Det tredje er direkte prosjektbevilgninger, som er strategisk bestilling av kunnskap om spesielle emner koblet til politikkutformingen. Især foregår dette ved sektorforskningsinstituttene.

\subsubsection{Institusjonelle rammer}

De institusjonelle rammene for utdanningsforskningen i Danmark er preget av både bredde og konsentrasjon. Allerede på slutten av 1800-tallet ble etter- og videreutdanning av folkeskolelærerne satt i system. Historisk løper en linje fra etableringen av Statens lærerhøjskole i 1904, frem til fusjonen av Danmarks Lærerhøjskole (DLH), Danmarks Pædagogiske Institut (DPI) og Danmarks Pædagoghøjskole (DPH) som ble til Danmarks Pedagogiske Universitet (DPU) i 2000. DPU omfattet også Center for Børnelitteratur samt forskningsenheten Learning Lab Denmark (LLD), og i 2007 ble Danmarks Pædagogiske Universitetsskole, Aarhus Universitet en realitet. Samme år ble det etablert åtte nye profesjonshøyskoler for blant annet lærer- og pedagogutdanningene i Danmark. Profesjonshøgskolene ligger ikke under universitetsloven og har ikke FoUforpliktelse på samme måte som universitetene, og heller ikke grunnbevilgninger til forsknings- og utviklingsarbeid.

Utdanningen av gymnaslærere har vært faglig, ikke pedagogisk forankret og har foregått ved universitetene. Skillet mellom universitetene som ligger under Ministeriet for Videnskab, Teknologi og Udvikling, og profesjonshøgskolene som ligger under Undervisningsministeriet bidrar i følge informanter i dette prosjektet til en svekkelse av utdanningsforskningens kobling til lærergjerningen og praksisfeltet. Det foregår likevel en del prosjektbasert utdanningsforskning finansiert gjennom eksterne midler ved profesjonshøgskolene. Dette har sammenheng med en økende grad av Ph.d.-kompetanse hos det faglige personalet ved profesjonshøgskolene. En viktig side ved dansk utdanningsforskning er således at den er influert av den sterke veksten i forskerutdannelsen med stipendfinansiering de senere år. 
DPU sto i 2004 for nærmere halvdelen av utdanningsforskningen i Danmark ifølge OECD-evalueringen, mens UH-sektoren samt instituttsektoren sto for den andre halvdelen. Imidlertid er mange av sektorforskningsinstituttene som ble etablert på 1960-tallet i dag sammenslått til større enheter i eller i tilknytning til universitetene, eller lagt ned.

\subsubsection{Forskningens innhold og resultater}

Informantene til dette prosjektet beskriver en tematisk utvikling av utdanningsforskningen i Danmark. På 1970-tallet er den kritiske empiriske forskningsinnsatsen rettet mot sosial bakgrunn, på 1980-tallet var kjønn i fokus, på 1990-tallet var system og organisasjon i fokus, mens på 2000tallet var etnisitet kommet i forgrunnen. Etterhvert har så disse perspektivene blitt sett i sammenheng. Dagens utdanningsforskning preges i følge informanter av en spenning mellom store prosjekter basert på surveydata, registerdata etc. og en kvalitativ og praksisnær forskning. Ved frittstående institutter foregår mest samfunnsvitenskapelig og psykologisk orientert kvantitativ forskning, mens utdanningsforskningen ved universitetene er overveiende kvalitativ småskala prosjekter rettet mot skolen og generell politikkutforming.

Dansk utdanningsforskning har best belyst grunnopplæringen og gymnasutdanningen, mens høyere utdanning er svakt belyst. Den utdanningsforskningen som har innretning mot grunnopplæringen er preget av en antropologisk tilgang til barn og unge, studier av klasserommet, samt medier, språk og kommunikasjon. Allmenndidaktikk og fagdidaktikk, spesielt innenfor språkopplæring, leseopplæring, naturfagene og matematikk har siden begynnelsen av 1990-tallet bygget opp miljøer som enda er forholdsvis små, men med sterke nordiske og internasjonale nettverk, i følge informantene. Det har foregått en internasjonalisering av utdanningsforskningen i Danmark de senere år, blant annet gjennom EU-prosjekter.

\subsection{Utdanningsforskning i Finland}

\subsubsection{Historikk}

I Finland har utdanningsforskningen en lang tradisjon, og kan tidfestes til opprettelsen av pedagogikk som vitenskaplig disiplin ved Universitetet i Helsinki i 1852. Argumentet for etableringen av denne disiplinen var at skoleutvikling må funderes på en systematisk forskningsbasert kunnskapsutvikling, et argument som fremdeles er sentralt i finsk utdanningspolitikk, ikke minst gjennom de reformer som ble gjennomført på 1970tallet (Westbury et al 2005). I dag foregår all lærerutdanning i Finland ved åtte universiteter, og de samme institusjonene står derfor også svært 
sentralt når det gjelder utdanningsforskning. Samtidig mener de informanter som vi har snakket med at utdanningsforskningsfeltet fremdeles står svakt i Finland sammenlignet med andre universitetsdisipliner, og at man har kjempet hardt for å få løftet feltet høyere opp på den forskningspolitiske agendaen.

\subsubsection{Politikk og utdanningsforskning}

Som nevnt kan etableringen av utdanningsforskningen i Finland knyttes eksplisitt til de politiske og nasjonale ambisjoner som har eksistert knyttet til utviklingen av grunnskolen. Slik sett har i alle fall den delen av utdanningsforskningen som er relatert til pedagogikk og didaktikk hatt en relativt sterk kopling til politiske aktører. Forskningen på feltet har generelt hatt som utgangspunkt at skoleutvikling er en viktig del av nasjonsbyggingen og velstandsutviklingen.

Samtidig har den universitetsbaserte organiseringen av lærerutdanningen også bidratt til frikopling fra en for detaljert politisk styring av forskningsaktiviteten. Utdanningspolitikken har fastsatt relativt tydelige rammer for virksomheten gjennom til dels sterkt fokuserte utdanningsforskningsprogram, mens fagmiljøene ved universitetene har hatt større frihet i forhold til hvordan man selv innretter sin forskningsvirksomhet. I praksis har universitetene likevel bedrevet forskning som oppfattes som relevant av praksisfeltet. Et sentralt kjennetegn ved forskning på skole og lærerutdanning i Finland har vært de mange aksjonsforskningsprosjektene som har vært bedrevet og som understreker forskningens ambisjon om å være relevant for sektoren (Bergem et al 1997: 436). Videre har også mange finske forskere jobbet aktivt på mange policyinitierte curriculumsutviklingsprosjekter. Samtidig har småskala dimensjoneringen på disse prosjektene gjort det vanskelig å trekke forbindelseslinjene tilbake til politikkutvikling siden designet på disse prosjektene ikke alltid har vektlagt muligheten for generalisering og kunnskapsoverføring.

\subsubsection{Institusjonelle rammer}

Som nevnt er utdanningsforskning i Finland i hovedsak lokalisert til de åtte universitetene som også tilbyr lærerutdanning. Dette innebærer at det er svært mange forskningsstillinger ved universitetene som også er sterkt knyttet til lærerutdanningsvirksomheten, men uten at man i et historisk perspektiv har klart å utnytte denne forskningsressursen optimalt. Selv om 40 prosent av tidsressursen formelt skal avsettes til forskning, synes det å være vanskelig å få til dette i praksis.

Samtidig har man i Finland også hatt en rekke nasjonale forskningsprogrammer som er utformet spesielt for utdanningsforskningsfeltet. Disse programmene kjennetegnes ved at de er forholdsvis sterkt fokuserte på 
spesielle temaer innenfor utdannings-forskningen: spesialpedagogikk, voksenpedagogikk, utdanningssosiologi, osv.

I Finland har man også etablert «the Finnish Educational Research Association» som i dag utgjør en viktig nasjonal møteplass for utdanningsforskning og forskere på feltet. Denne organisasjonen kan leses som et uttrykk for et behov for å se de spesialiserte studieområdene innen utdanningsforskningen mer i sammenheng. Etableringen av ulike forskerskoler innen utdanningsforskningsfeltet er også et markant utviklingstrekk det siste tiåret.

\subsubsection{Forskningens innhold og resultater}

Selv om utdanningsforskning i Finland har en historie og et utgangspunkt sterkt koplet til skole, skoleutvikling og lærerutdanning, har feltet forandret seg mye de siste tiårene (se også Bergem et al 1997; Westbury et al 2005). Våre informanter mener å kunne se en utvikling der man på 1980tallet hadde et sterkt fokus på didaktikk, undervisning og læreplansforskning og fag(emnes-)didaktikk, til at man på 1990-tallet i større grad fikk en orientering mot de sosiale sidene ved skole og utdanning, herunder mer utdanningssosiologiske temaer, mobbing, forholdet skole-samfunn, elevinteraksjon. I stor grad har man også initiert forskning som er drevet av ulike politiske agendaer, herunder analyser av skoleprestasjoner, lærerutdanningen i et profesjonsperspektiv, samt styring og ledelse av skole og utdanning i mer overordnet systemperspektiv. Etter 2000 mener våre informanter å se at utviklingen i forhold til bredden i problemstillingene har fortsatt. Man ser eksempler på forskning som er mer rettet inn mot utdanningsfilosofiske og utdanningshistoriske problemstillinger, samt forskning som har et sosialkonstruktivistisk utgangspunkt.

Når det gjelder innretningen på forskningen i Finland hadde man historisk sett en individualistisk forskningsinnsats gjerne knyttet til mindre prosjekter med et lokalt nedslagsfelt både empirisk og formidlingsmessig. Her mener informantene at det har skjedd store endringer i retning av mer samarbeid, og nasjonale, gjerne multidisiplinært orienterte forskningsprogrammer. Nettverksorganisering som utgangspunkt for prosjekter der minst tre universiteter samarbeider, tillegges stor betydning for denne utviklingen. Samtidig påpeker enkelte av informantene at dette ikke alltid har styrket nettverksaktiviteten innen landets grenser, men like gjerne stimulert til faglig samarbeid med institusjoner og miljøer i andre land.

Innenfor de åtte universitetene hevder informantene at man også kan se tendenser til spesielle faglige profiler selv om eksempelvis studier knyttet til IKT, læring og psykologi, samt prosjekter knyttet til emne/fagdidaktikk i dag drives ved mange ulike institusjoner. Som eksempler på institusjonelle profiler nevnes at man ved Universitetet i Helsinki har en profil sterkt knyttet til læringsprosesser og aktivitetsteori, samt bruk at ny teknologi; at forskningen ved Universitetet i Oulu 
ofte kjennetegnes av en mer narrativ orientering knyttet til organisasjonslæring og læring gjennom praksis; at man ved Universitetet i Jyväskylä har en styrke innen utdanningspsykologiske studier, didaktikk innen naturvitenskap og teknologi, samt studier av høyere utdanning; at man ved Universitetet i Turku er kjennetegnet av en sterkt policyorientering, og da spesielt i forhold til lærerutdanningsfeltet; at man ved Universitetet i Tampere er kjent for sine studier inne voksenpedagogikk og studier av høyere utdanning.

\subsection{Utdanningsforskning på Færøyene}

\subsubsection{Historikk}

$\AA$ beskrive utdanningsforskning på Færøyene er en forholdsvis enkel oppgave hvis man ønsker å ta utgangspunkt i forskningsinnsats og produksjon. Sett i et slikt perspektiv er både innsats og resultater ganske beskjedne. Årsaken er selvfølgelig knyttet opp til sentrale kjennetegn ved det Færøyske samfunn. På en øygruppe med en liten befolkning, og der samfunnet i mange år var sterkt koplet til Danmark, var autonomien i forhold til utdanningssektoren beskjeden, og ressursene små i forhold til denne typen satsning.

I dag har Færøyene sitt eget universitet (opprinnelig etablert som et selveiende akademi på 1960-tallet), og man har en systematisk satsning på utdanningsforskning, med en avdeling for pedagogikk og lærerutdannelse, etter at universitetet i 2008 fusjonerte med lærer- og pedagogikkutdannelsen og sykepleierutdannelsen og med dette tredoblet antallet studenter. Det felles navn for de fusjonerte institusjoner er Fróðskaparsetur Føroya, en institusjon som hører under Mentamálaráðið, det færøyske ministerium for undervisning, forskning og kultur.

Sett i et historisk perspektiv er imidlertid utdanningsforskning på Færøyene først og fremst knyttet til lærerutdanningsaktiviteter. Det selveiende akademi skulle drive med etterutdanning av lærere, og aktiviteten var i hovedsak knyttet opp til ulike årskurs for lærerstanden (Pedersen 1994: 273). Akademiet fikk universitetsstatus i 1990, og har senere ekspandert sitt utdanningstilbud. I forhold til forskning på skolesektoren har imidlertid universitetet spilt en beskjeden rolle, først og fremst fordi tyngdepunktet har ligget på å tilby utdanning, men også fordi en del av de enkeltpersoner som kan sies å ha en tilknytning til feltet ikke nødvendigvis har hatt tilhold der, men har utført sin forskning ved institusjoner utenfor Færøyene (oftest i Danmark). 


\subsubsection{Politikk og utdanningsforskning}

Koplingen mellom politikkfeltet og utdanningsforskningsfeltet kan sies å være preget av at man fra politisk hold har hatt en mer instrumentell holdning knyttet til hva forskningen kan bidra med i forhold til utvikling av skolen. De få mer systematiske undersøkelsene som har vært utført har alle hatt veldig konkrete utgangspunkt, og har gjerne vært generert ut fra hensyn som har vært høyt oppe på den politiske agendaen. Eksempler er her knyttet til leseferdigheter og språkspørsmål, der disse temaer igjen gjerne er knyttet til spørsmål om Færøysk identitet og autonomi (jfr Pedersen 1994: 337). Hos politikerne har interessen i hovedsak vært rettet på grunnskolen og dens utvikling, og mulighetene for å utvikle et bærekraftig og selvstendig samfunn.

\subsubsection{Institusjonelle rammer}

Selv om de institusjonelle rammene rundt aktiviteter på utdanningsforskningsfeltet er beskjedne når det gjelder systematiske studier og forskningsprogrammer, synes det i dag å foregå en større formell kompetanseoppbygging på feltet, og ønsket om større konsentrasjon og koordinering står sentralt. Dette har uten tvil sammenheng med behovet for å styrke universitetet på Færøyene som i dag har 450 studenter. Den nylige sammenslåingen av Færøyenes Lærerhøyskole med universitetet er i så måte et uttrykk for det samme.

Det finnes flere stipendiater som i dag er i gang med sin doktorgrad knyttet til temaer som er svært relevante for utdanningsforskningsfeltet. Ikke alle disse er lokalisert på Færøyene, men tar sin grad ved danske universiteter. Det er imidlertid i dag også flere unge forskere som arbeider med utdanningsforskning på Færøyene.

\subsubsection{Forskningens innhold og resultater}

Forskningsaktiviteten innenfor utdanningsforskning på Færøyene har flere distinkte kjennetegn: For det første er forskningens innhold i all hovedsak rettet mot grunnskolenivået, og relatert til elevenes ferdigheter, kompetanse og læring.

For det andre er den aktivitet som har pågått relativt kvantitativt orientert, og sterkt koplet til ulike typer tester. Den siste typen av studier har blant annet vært muliggjort ved at man på Færøyene har tilgang på relativt gode registerdata som også kan brukes til forskningsformål, selv om dette materialet på langt nær oppfattes å være godt nok utnyttet. Et eksempel på mer kvalitativt orienterte studier er at det i etterkant av at Færøyene har deltatt i PISA-studien, har vært økende interesse for spørsmål knyttet til kunnskapsnivået i ulike basisfag. Et prosjekt om lesing og leseferdigheter ved den daværende lærerhøyskolen som startet i 2007 kan nettopp sies å ha preg av å være en oppfølgingsstudie til PISA. 
Et tredje kjennetegn ved forskningsaktiviteten på Færøyene er at den i stor grad er koplet til konkrete utviklingsprosjekter. Slik sett er aktiviteten i praksis et markant innslag av «aksjonsforskning» selv om aktørene selv ikke nødvendigvis klassifiserer sin aktivitet med dette begrepet.

Resultatene fra forskningen er i hovedsak rapportert i mer lokale kanaler - herunder i rapporter til forvaltningen eller i andre former for rapporter, og mer allmennrettet formidling, tidligere i rapporten omtalt som «grå litteratur» (se kap. 2). Forskningsformidling i mer tradisjonelle vitenskaplige tidskrift er sjeldnere, selv om man kan finne forfatteradresser på Færøyene i den bibliometriske kartleggingen som også er en del av denne studien (se Appendiks 4). I tråd med beskrivelsene av aktiviteten på dette feltet, er imidlertid forfatternavnene spredt på en rekke forskjellige institusjoner, noe som understreker den mer individuelle og fragmenterte profilen på utdanningsforskningsfeltet på Færøyene, samt det institusjonelle landskapet.

\subsection{Utdanningsforskning på Island}

\subsubsection{Historikk}

Utdanningsforskningen på Island kan tidfestes til begynnelsen av 1950tallet da Universitetet på Island opprettet et eget institutt for pedagogikk. Samtidig strekker historien seg lengre tilbake. Island hadde allerede i 1907 en egen lærerhøyskole hvor det tidvis var aktiviteter som hadde berøringspunkter til forskning. Som i mange andre nordiske land har utdanningsforskningen i store trekk vært orientert mot lærerutdanning og skoleforskning, men dette har endret seg det seneste tiåret. I dag kan man identifisere et bredere forskningsfokus på Island, samtidig som det også har skjedd en del strukturelle endringer når det gjelder rammebetingelsene for utdanningsforskning.

\subsubsection{Politikk og utdanningsforskning}

Islandsk utdanningsforskning har hatt få og fragmenterte kontakter med politiske aktører, noe som kan ha sammenheng med at den politiske styringen av lærerutdanningen har vært relativt svak på Island. Mens myndighetene $\mathrm{i}$ en del andre land utarbeider mer overordnede retningslinjer som styrer innholdet i lærerutdanningen, har slik politisk påvirkning vært mer beskjeden på Island. Det er lærestedene selv som har myndighet til å utforme curriculum, selv om det eksisterer sterke politiske styringssignaler når det gjelder kunnskapsinnholdet i skolen. En evaluering av utdanningsforskning på Island viste at mange forskere antar at deres forskning er relevant for myndighetene, selv om det ikke er etablert systematiske mekanismer for å øke relevansen av forskningen (Rannis 2005: 263). 
Samtidig er en del av forskningen som utføres av anvendt karakter (evalueringer og ulike typer tester), og bærer preg av å være bestillingsoppdrag fra politisk hold. Ikke minst er mye av den forskning som utføres av mer eller mindre frittstående institutter på Island av en slik karakter (Rannis 2005: 250). Dette forhindrer likevel ikke at mange forskere mener at både politikk og praksis er viktige adressater i formidlingen av forskningen. Macdonald et al (2005) antyder at en slik holdning kan ha sammenheng med at mange av de publikasjoner som er skrevet ikke er publisert i fagfellevurderte tidsskrifter, og at de ofte er ment som «svar» på bestemte politiske eller utdanningsmessige utfordringer. Et problem som blir påpekt av informanter er imidlertid at forskerne i liten grad har kunnskap om denne type formidling faktisk brukes av eller treffer disse målgruppene.

\subsubsection{Institusjonelle rammer}

I dag er tyngdepunktet for utdanningsforskningen på Island konsentrert om to universiteter: Universitetet på Island og Universitetet i Akureyri. I tillegg utføres utdanningsforskning også som en del av ulike utviklingsprosjekter i utdanningssektoren, i ulike institutter, samt at ulike instanser i privat sektor har aktiviteter som grenser opp til forsknings- og utviklingsarbeid (Rannis 2005: 256).

I tillegg foregår det utdanningsforskningsrelatert virksomhet i ulike frittstående institutter hvor The National Testing Institute er det viktigste. At det kun er to universiteter som i dag driver med utdanningsforskning handler imidlertid også om at det institusjonelle landskapet har vært og er i endring. Den opprinnelige lærerhøyskolen fikk universitetsstatus i 1971, og ble i 1999 slått sammen med andre lærerutdanninger og med ny lov ble navnet endret til Islands Pedagogiske Universitet, med rett til å tildele doktorgrader. I 2008 ble denne institusjonen slått sammen med Islands Universitetet og med en «School of Education». På denne måten er de tendenser til oppgradering og konsolidering som man finner $\mathrm{i}$ andre nordiske land, også gjeldende på Island.

Til tross for en organisatorisk konsolidering på Island, er utdanningsforskningen relativt individualistisk organisert. Som Macdonald et al (2005: 8-9), har påpekt, er rundt 70 prosent av publikasjonene med en universitetsadresse skrevet av kun en person, og flertallet av de prosjekter forskerne arbeider på er også individuelle. Selv om disse tallene er noen år gamle indikerer de likevel et mønster som det kan være vanskelig å endre på kort tid. I de senere årene kan man se ulike forsøk på å bruke forskningsprogrammer og andre nasjonale initiativ for å stimulere til økt samarbeid. Disse nasjonale forskningsinitiativene er imidlertid brede satsninge. De er ikke spesielt fokusert eller innrettet mot utdanningsforskning, men har gjerne hatt en tematisk forankring i forhold til ny teknologi eller lignende temaer. Av utfordringer som informantene trekker 
frem, er spesielt forskningsrekruttering nevnt, og at utdanningsforskningsfeltet ikke har hatt egne nasjonale forskningsprogrammer som har kunnet samle forskerne og forskningen på feltet.

\subsubsection{Forskningens innhold og resultater}

Informantene som er intervjuet i forbindelse med dette prosjektet understreker at utdanningsforskning på Island i dag er relativt mangfoldig, og at dette er en utvikling man spesielt har sett i det siste tiåret. Den viktigste årsak til denne utviklingen synes å være at fokuset ikke lenger eksklusivt er knyttet til pedagogisk/didaktisk forskning i skolen, men er utvidet ved at andre disipliner har kommet til. Forskningsfokuset er dermed også utvidet til å omfatte andre temaer så som kjønn og utdanning, skoleledelse og multikulturell utdanning.

Samtidig snakker vi ikke her om en radikal omveltning. De forskningsfelter informantene mener fremstår som svært sentrale, vurdert etter omfang og kvalitet, er fremdeles forskning på grunnskolen og dets virkemåte herunder studier av lærerprofesjonen, forskning på forholdet mellom utdanning og samfunn, forskning på enkeltfag i grunnopplæringen (matematikk, språkfag, etc), samt mer psykologisk orientert læringsforskning, spesialpedagogikk og forskning på barnehage og førskolepedagogikk. Fremdeles er det imidlertid lite forskning som kan karakteriseres som tverrfaglig; den mer individorienterte praksisen knyttet til forskningsfeltet generelt innebærer i hovedsak en flerfaglig tilnærming.

I forhold til metodikk og forskningsdesign er informantene av den formening at mesteparten av forskningen er kvalitativt orientert. I en kartlegging av utdanningsforskningen på Island i perioden 1998-2002 kom det frem at det ved universitetene er grunnforskning som dominerer, men at rundt en tredjedel av forskningsaktiviteten kan sies å være anvendt. Svært mye av resultatene ble formidlet muntlig gjennom konferanser og utarbeiding av posters, og kun 10-15 prosent av aktiviteten var rettet mot artikler i fagfellevurderte tidsskrift (Macdonald 2005: 4-5). Selv om våre informanter mener de har sett en tydelig dreining i retning av mer vekt på vitenskaplig publisering, og ikke minst publisering internasjonalt, synes det å være stor enighet om behovet for et enda sterkere fokus på dette i årene som kommer.

\subsection{Utdanningsforskning i Norge}

\subsubsection{Historikk}

Utdanningsforskningen i Norge er knyttet til institusjonelt mangfold, og kan tidfestes til opprettelsen av et professorat i pedagogikk ved Universitetet i Oslo i 1938. Før dette fantes praktisk-pedagogisk utdanning for 
universitetskandidater som ønsket å bli lærere, og lærerutdanninger ved egne høyskoler rundt om i landet. Utviklingen av en desentralisert høyere utdanning på 1970-tallet, og etableringen av distriktshøyskoler som tilbød universitetsfag, har hatt stor betydning for utdanningsforskningen. Høyskolereformen i 1995 samlet universiteter og høyskoler under en felles lov, og dette førte til sammenslåing av tidligere lærerutdanninger og andre postgymnasiale utdanninger til 29 høyskoler. På 2000-tallet har to av disse høyskolene blitt universiteter, og det pågår flere sammenslåingsprosesser mellom høyskoler og universiteter i Norge i dag.

\subsubsection{Politikk og utdanningsforskning}

Frem til slutten av 1980-tallet var utdanningsforskningen i stor grad synonymt med pedagogikk og primært finansiert via fagdisiplinen, i tillegg til grunnbevilgningene ved lærestedene. Med de første utdanningsforskningsprogrammene kom en forholdsvis bredt innrettet finansiering på feltet. Deretter kom programmer med mer snever satsning og med følgeforskning i tilknytning til utdanningsreformer i opplæringen. Pedagogikken har imidlertid hatt forholdsvis lite gjennomslag i disse programmene, slik at grunnbevilgningen i UoH-sektoren har vært sentral ressurs for denne forskningen.

Historisk sett kan forholdet til politikkutformingen i Norge i følge informanter i dette prosjektet beskrives som ambivalent; utdanningsforskningen har på mange måter vært reformlojal og reformkritisk på samme tid. Mye av forskningen har vært rettet mot «intensjonsplanet» i politikken og utdanningsforskningen har i mindre grad bidratt med implementeringskunnskap og kunnskap om resultater. Informanter oppgir at dette har ført til en politisk mistillit til utdanningsforskningen, og at den har blitt oppfattet som lite relevant for politikkutformingen. Utover 1990-tallet har en veldig egendynamikk preget høyere utdanning og bidratt til at utdanningsforskingen har blitt styrket. Dette har sammenheng med høyskolereformen og institusjonelle endringsprosesser, akademisering av lærerutdanningen og behovet for kompetanseheving, i tillegg en generell utdanningsvekst. Samtidig har 1990-tallet vært preget av store reformer i opplæringen, og sammen med resultatfokuset som følge av PISAstudiene etc. har dette også preget 2000-tallet.

Reformevalueringene førte med seg mye ressurser, og har gjort at mange utdanningsforskere har vært engasjert i denne type policyorienterte evalueringsprosjekter. Det har vært mindre grad av grunnforskningsorienterte problemstillinger og prosjekter. Kunnskapsdepartementet har utarbeidet en strategi for utdanningsforskning for perioden 2008-2013; Kunnskap for kvalitet, som peker på behovet for en styrking av omfanget, kvaliteten og relevansen i forskning for sektoren og om sektoren. 


\subsubsection{Institusjonelle rammer}

Satsningen på desentralisert høyere utdanning og en utbygd samfunnsvitenskapelig instituttsektor bidrar til at utdanningsforskningen i Norge foregår i mange forholdsvis små miljøer og har stor bredde. Dette er også et mønster som ble påpekt $\mathrm{i}$ evalueringen av norsk pedagogisk forskning (Norges forskningsråd 2005). Mens utdanningsforskningen inntil 1970tallet var dominert av pedagogisk psykologi, har mye av forskningen etter dette vært individbasert, med parallell forskning ved flere institusjoner, noe som har resultert i miljøer uten en tydelig faglig profil. På 2000-tallet har det pågått en prosess med å styrke forskningen ved bruk av større og mer systematiske strategiske forskningsinnsatser i UoH-sektoren, noe som også kan knyttes opp mot sammenslåingsprosesser som pågår. Instituttsektoren er mangfoldig, men robust på utdanningsforskningsfeltet.

\subsubsection{Forskningens innhold og resultater}

Historisk sett har utdanningsforskningen i Norge vært preget av tematisk bredde og med til dels motsetningsfylt forhold mellom teori og praksis, en spesialpedagogisk innsats, sosiologiske perspektiver samt en innsats med filosofiske og normative innslag (Vislie 2002, Norges forskningsråd 2005). Dette sammensatte bildet kan knyttes til et institusjonelt mangfold av forskningsutførende miljøer ved universiteter og høgskoler, og der enkeltpersoner ivaretar spesialiseringer. Mens de tradisjonelle miljøene innenfor pedagogikkfaget har hatt fokus på reformer og på individuelle forhold i opplæringen, har instituttsektoren hatt større fokus på videregående opplæring, fagopplæring og høyere utdanning. Profesjonsstudier er et område som har fått økt interesse de siste 10 årene, og med oppbygging av noen sentrale miljøer innenfor høgskoler som gir utdanning innenfor velferdsstatens profesjoner. Det er også miljøer rundt didaktikk og klasseromsforskning, og fagdidaktikk spesielt innenfor naturfagene, matematikk og lesing i UoH-sektoren. I tillegg har sosiologisk orienterte utdanningsstudier belyst sosial reproduksjon og ulikhet, særlig innenfor videregående opplæring og høyere utdanning. Utdanningsforskningen er forholdsvis mager når det gjelder studier av strukturelle forhold knyttet til utdanning som del av det moderne, og institusjonaliseringen av utdanningen.

Utdanningsforskningen blir fortsatt identifisert med pedagogikk, for eksempel har programmet Utdanning 2020 en tverrfaglig innretning som skal favne «mer enn pedagogikk». Lærerutdanningene har vært preget av forholdsvis mager forskning innenfor opplæringen og egen utdanning, derimot er det forholdsvis sterk tradisjon innenfor lærerutdanningen med lærebokproduksjon rettet mot opplæringen og lærerutdanningen. Barnehageforskningen er styrket de senere år. I tillegg er praksisrettet FoU i lærerutdanningen styrket blant annet gjennom programsatsninger, forskerutdanning og nylig i egen forskerskole. 


\subsection{Utdanningsforskning i Sverige}

\subsubsection{Historikk}

Utdanningsforskningen i Sverige har en om lag hundre år lang historie. Det første professoratet i pedagogikk ble opprettet ved Uppsala Universitet i 1910 og var begrunnet i behovet for utdanning av lærere til gymnaset og til lærerutdanningene (Lindberg 2002). Utdanningsforskningen preges av stor bredde og er spredt ut over lærestedene i Sverige, men preges samtidig av noen miljømessige tyngdepunkt ved enkelte læresteder. Historisk sett illustrerer antall professorer i pedagogikk mønstre og endringer i utdanningsforskningsfeltet, i følge informanter som er intervjuet for dette prosjektet. I 1947 var det fire professorer i pedagogikk, en ved hvert av fire svenske læresteder, og i 2009 fins mer enn 120 professorer innenfor pedagogikk. Denne utviklingen kan blant annet ses i sammenheng med at lærerutdanningene i 1977 ble inkorporert i universitets- og høgskoleloven med forskningskrav. I dag er det lærerutdanning ved 26 læresteder (ved 10 universiteter og 16 høyskoler) i Sverige. ${ }^{3}$

\subsubsection{Politikk og utdanningsforskning}

Fremveksten av utdanningsforskningen i Sverige preges av komplekse politiske og strukturelle endringsprosesser med betydning for rammebetingelsene for utdanningsforskningen, og stadig pågående grenseoppganger når det gjelder spørsmål om kvalitet og relevans (jfr Askling 2006:131). Sektorforskning for å besvare kunnskapsbehov i tilknytning til opplæringen har i perioder stått sterkt. Ikke minst har ressurstilgangen både innenfor sektorforskningen og i det bredere utdanningsforskningsfeltet fungert formativt, med nasjonale organisatoriske og administrative strategiske tiltak i samspill med lærestedene og forskersamfunnet.

Ved siden av grunnbevilgningene til lærestedene representerer Vetenskapsrådets utbildningsvetenskapliga kommitée (UVK) fra 2001 en sentral strategisk ressursinnsats for utdanningsforskningen. UVK har lagt til grunn en bred definisjon av utdanningsforskningen der kunnskapsobjektet konstitueres som et flerfaglig og delvis tverrfaglig forskningsfelt som inkluderer en rekke ulike fagdisipliner og forskningstradisjoner med organisatorisk tilknytning til ulike vitenskapsområder, fakulteter og grunnenheter ved svenske læresteder. Utdanningsforskningen som studieobjekt gis en bred definisjon. Kravet om at forskningen skal ha relevans for lærerutdanning og pedagogisk yrkesvirksomhet møtes gjennom forskning som fokuserer på danning, oppdragelse, utdanning, undervisning og læring i skolevesenet så vel som på andre arenaer (Aasen m.fl.

\footnotetext{
${ }^{3}$ I følge Högskoleverkets portal Studera.nu, lest 28.10.09 på nettadressen: https://www. studera.nu/studera/2563.html
} 
2005). Sentrale strategiske virkemidler er prosjektstøtte med krav om samarbeidende miljøer, rekrutteringsstipend og forskerskoler.

\subsubsection{Institusjonelle rammer}

Utdanningsforskningen foregår ved lærestedene i Sverige, mens den frie instituttsektorens rolle er svært svak. Som nevnt fins i dag lærerutdanning ved 26 læresteder (ved 10 universiteter og 16 høyskoler) i Sverige, og forskningsinnretningen er styrket gjennom sterk økning i antall disputerte blant de som underviser i lærerutdanningen.

Det er stor variasjon når det gjelder institusjonell og fakultetsmessig organisering av pedagogikkfaget og lærerutdanningen ved lærestedene, noe som kobles til diskusjoner om pedagogikkfagets identitet og akademiske status og legitimitet, og om dets nytte i forhold til profesjoner osv. som pågår med ulik intensitet og valør ved lærestedene (Askling 2006:111).

Kravet til samarbeid mellom læresteder fra UVK virker formativt på det strategiske samarbeidet innenfor og mellom institusjoner, og når det gjelder den pedagogiske, den tverrfaglige og flerfaglige organiseringen av utdanningsforskningen.

\subsubsection{Forskningens innhold og resultater}

Den pedagogiske forskningen ble tidlig synonymt med utdanningsforskning i vid forstand, samtidig som tidvis nærhet og distanse mellom politikkfeltet og utdanningsforskningsfeltet, har preget utdanningsforskningen. Myndighetsdefinerte prosjekter innenfor grunnopplæring kom særlig til å prege utdanningsforskningen i etterkrigstiden på bakgrunn av 1940og 1950-årenes store skoleutredninger og den obligatoriske skolens utvikling. På 1970-tallet var det en styrking av ressurstilgangen og samtidig nedtoning av innretningen mot politikkfeltets kunnskapsetterspørsel til fordel for forskerdrevet virksomhet. Oppmerksomheten ble rettet mot kvalitet og relevans for opplæringen og det direkte lærerarbeidet. På 1980-tallet vokste allmenndidaktikk og fagdidaktikk fram via pedagogikken, og etter hvert også via fagene. En forsterket sektorforskning på 1990-tallet samtidig med en styrking av lærerutdanningen preger dagens utdanningsforskning (Aasen \& Prøitz 2004, Englund 2004). Om lag halvparten av forskningstøtten gjennom UVK går til pedagoger. Samtidig foregår utdanningsforskning med støtte fra UVK i mange disipliner og belyser kunnskap og læring i vid forstand.

I dag fremstår forskningsaktiviteten som pluralistisk med ulike metodeinnretninger og teorivalg, hovedsakelig kvalitativ forskning med konsentrasjon rundt individuell utvikling og læring, klasseromsforskning, samt didaktikk, særlig knyttet til grunnopplæringen. 
Mens grunnopplæringen er godt belyst i ikke-generaliserbare studier, er det svak forskningsaktivitet angående strukturelle forhold og systemspørsmål. Det blir av informanter påpekt som et paradoks at samtidig som det skjer store endringer innenfor utdanningsfeltet, fins omtrent ikke studier av endring. Studier av høyere utdanning er heller ikke et særlig fremtredende forskningsområde i dag. En styrke som påpekes er at man har etablert registerdata og store statistisk representative utvalg av elever og studenter, noe som gir grunnlag for longitudinelle studier.

Selv om utdanningsforskningen foregår ved alle lærestedene, er det ulike skoler og tradisjoner på de ulike lærestedene, og visse områder innenfor utdanningsforskningen er som nevnt sterkt knyttet til personer og miljøer. Forskerskoler bidrar til nasjonal utnyttelse av slike krefter overfor nye forskerstuderende.

\subsection{Sammenfatning av noen sentrale kjennetegn}

Historisk sett viser denne kvalitative gjennomgangen at de nordiske landenes utdanningsforskning har vokst frem i forhold til opplæringen og lærerutdanningen og at oppbyggingen av pedagogikkfaget som akademisk disiplin har vært viktig for å besvare og bidra til kunnskapsbehovene i sektoren. Et trekk i flere av landene kan likevel synes å være et ambivalent og spenningsfylt forhold mellom utdanningsforskningen, lærerutdanningen og det akademiske pedagogikkfaget. Utdanningsforskningen i landene preges av ulike historiske prosesser der politikkutforming og ressurstilgang, oppbyggingen av læresteder og miljøer, og ikke minst enkeltpersoner spiller sammen.

Når det gjelder forholdet mellom politikk og utdanningsforskning utpeker Finland seg som et land med lange tradisjoner for tette bånd og lavt spenningsnivå i relasjonen mellom lærerutdanningen og pedagogikkfaget som akademisk disiplin. Det ser ut til at både politikkutforming og ressurstilgang og andre strukturelle forhold bidrar til dette. Danmark har en del motsatte kjennetegn gjennom at lærerutdanningene har stått og stadig står utenfor universitetene, og at politikkutforming og ressurstilgang på feltet har gitt feltet varierende vilkår for utdanningsforskningen.

Generelt preger institusjonelle endringsprosesser relasjonene mellom lærerutdanning og pedagogikkfaget i landene, og for eksempel Island, som har tradisjon for sterkt autonom lærerutdanning, har nylig slått sammen universitetene og lærerutdanningene.

De institusjonelle rammer og politikken synes å spille sammen når det gjelder forholdet mellom den praksisrettede og den grunnforskningsrettede kunnskapsproduksjonen innenfor utdanningsforskningen. Dette forholdet bærer preg av de nevnte spenningene mellom lærerutdanning og pedagogikk som akademisk disiplin. Også her kan det se ut til at utdanningsforskningen i Finland utpeker seg med lavt spenningsnivå. Lærerutdanningene 
ved universitetene i Finland synes å være praksisorientert, og et sentralt kjennetegn ved forskningen er relevansorienteringen gjennom de mange aksjonsforskningsprosjektene og curriculumsutviklingsprosjekter. Her kan det se ut til at politikken i samspill med ressurstilgangen, for eksempel i Norge og Sverige gir andre føringer for kunnskapsproduksjonen. De senere år har betingelsene i Norge blitt styrket gjennom programmer både i forhold til praksisrettet og grunnforskningsrettet utdanningsforskning. Noe lignende kan sies å være tilfellet for utdanningsforskningen i Sverige gjennom at UVK representerer en mer grunnforskningsrettet ressurstilgang. Men i begge landene foregår utdanningsforskning, ofte i liten skala, ved mange læresteder og miljøer.

Innholdsmessig har utdanningsforskningen i de nordiske landene vært preget av endringer de siste ti årene, mot spredning og økt mangfold i innretning og metoder og i nye samarbeidsformer. Utdanningsforskningen i de nordiske landene er dermed mer enhetlig enn man kunne forventet ut fra ulikhetene mellom landene når det gjelder hvordan politikkens relevanskrav og ressurstilgang gir føringer for retninger og veivalg, samt de ulike institusjonelle rammer. Gjennomgående ser det ut til at 1980tallet var preget av fokus på forutsetningene for læring, og der allmenndidaktikk, fagdidaktikk og læreplanforskning har vært sentrale tema. Derimot ser det ut til at 1990-tallet i større grad har vært preget av utdanningssosiologiske tema samt forskning knyttet til reformer og med økende fokus på resultater. På 2000-tallet utbredes utdanningsforskningen i mange retninger og blir mer tverrfaglig og flerfaglig innrettet, noe som også innbærer at læring på mange ulike arenaer studeres. Likevel kan det se ut til at historiske linjer videreføres i de ulike landene. Gjennomgående beskrives mye av utdanningsforskningen i de nordiske landene som kvalitativt innrettet småskala forskning, samtidig som denne forskningen ser ut til å være av relevans for praksis, spesielt i opplæringen. Som det fremgår av kapittel 3 har flere av landene de senere år programsatsninger som er rettet mot større tverrfaglige og flerfaglige prosjekter.

Selv om det neppe kan sies å være direkte spor etter programinnsatser, er det likevel tydelig at for eksempel utbygging og reformer i norsk høyere utdanning har satt preg på forskningen og muligheten for å bygge opp miljøer med kompetanse på dette feltet i Norge, mens dette står svakere i en del av de andre landene.

Noe tilsvarende ser ut til å gjelde forskningen i forbindelse med reformer i videregående opplæring og fagopplæring, der det er bygget opp miljøer med kompetanse på feltet i Norge mens det står svakere i en del av de andre landene. Selv om det fins en del gjennomstrømningsstudier, har det imidlertid vært svak ressursinnsats særlig når det gjelder innholdet i videregående opplæring og fagopplæringen i de nordiske landene, og dette gjenspeiles tilsvarende i utdanningsforskningen.

På tross av stor tematisk bredde og variasjon i nordisk utdanningsforskning er det visse områder som er usynlige her. Dette gjelder særlig 
kunst- og kulturfagene (som gjerne betegnes estetiske/musiske fag), som har en forholdsvis stor plass i grunnopplæringen i alle de nordiske landene og et nordisk særpreg innenfor høyere kunstutdanning.

Publisering og formidling foregår som det fremgår av kapittel 2, i stor grad på lokalt og nasjonalt nivå og i mer allmennrettede kanaler, mens noen miljøer og fagområder er mer interasjonalt orienterte i formidlingen. Dette bildet bekreftes av informantene som er intervjuet. I nordisk sammenheng har det imidlertid vært veletablerte arenaer for forskningsintern formidling gjennom bl.a. Nordisk Forening for Pedagogisk Forskning (NFPF), som av informanter i dette prosjektet er omtalt som en vital og viktig møteplass både av fagpedagoger og forskere fra andre fagdisipliner.

Et interessant trekk innenfor utdanningsforskningen er imidlertid utviklingen av forskningsinterne møteplasser for relevans- og kvalitetsdiskusjoner, som registreres i forbindelse med landenes eksterne forskningsfinansiering (se kap. 3), dvs. den som ikke går over grunnbevilgningene til lærestedene. I Sverige er det krav om samarbeid mellom læresteder for å få midler i UVK. I Finland er det nye programmer basert på nettverksorganisering både nasjonalt og internasjonalt, og det er dessuten etablert et Finnish Educational Research Association som er en viktig møteplass for finsk utdanningsforskning.

Det er ikke grunnlag for å konkludere med at noen bestemte miljøer utmerker seg innenfor nordisk utdanningsforskning. Strukturelle forhold ser ut til å gi landene et felles preg, nemlig at pedagogikkfaget har fătt en tydeligere posisjon, samtidig som utdanningsforskningsfeltet utvides og er blitt mer mangfoldig. Både i Norge og Sverige avtegnes dette gjennom at mange nye fagmiljøer lykkes i å få tilgang til forskningsressurser samtidig som også pedagogene ser ut til å lykkes i større grad enn tidligere, og i Finland ser det ut til at den tradisjonelt tette kobling mellom lærerutdanning og pedagogikk står sterkt. Dermed fremstår utdanningsforskningen både som tverrfaglig og flerfaglig, samtidig som pedagogikkfaget har relevans i forhold til innretningen. Det kan tenkes at sammenslåingene av lærerutdanningsinstitusjoner og universiteter og nye former for samarbeidskonstellasjoner kan bidra til en slik tettere kobling innenfor utdanningsforskningen i flere av de nordiske landene på lengre sikt, selv om det antagelig stadig vil være tematiske, strategiske og personavhengige variasjoner. 



\section{Konklusjoner og anbefalinger}

\subsection{Innledning}

Å få gjennomført nordisk samarbeid om forskningsprogram, infrastruktur etc er relativt krevende ettersom de enkelte land har ulike systemer for organisering og finansiering av forskning. Det kan også by på utfordringer siden det overnasjonale samarbeidet baseres på finansielle bidrag fra medlemslandene. De forslag til videre samarbeid som fremmes i denne rapporten må forstås i relasjon til de eksisterende former for nordisk forskningssamarbeid som har vist seg fordelaktig og levedyktig.

I de foregående kapitler er det gjort et kartleggingsarbeid når det gjelder utdanningsforskning som svarer på flere av de spørsmål som prosjektet er bedt om å vurdere:

- I kapittel 2 ble det gjort en innledende analyse ved hjelp av bibliometrisk metode av arbeider publisert i utvalgte internasjonale tidsskrift. Hensikten med dette kapittelet var både å kartlegge publiseringsmønstre og identifisere forskningsutførende miljøer i Norden, men også å få en indikasjon på hvilke miljøer som er synlige i en internasjonal kontekst.

- I kapittel 3 ble fokus satt på forskningsfinansiering, nasjonale forskningsinitiativ og en vurdering av de forskningsformidlingstiltak som er etablert i de ulike landene.

- Kapittel 4 inneholder en overordnet beskrivelse av utdanningsforskningsfeltet i de enkelte nordiske land basert på en serie kvalitative intervjuer og sekundærlitteratur på feltet. Avslutningsvis i kapittelet ble sentrale kjennetegn ved utdanningsforskningsfeltet i Norden beskrevet.

I tillegg har Nordisk ministerråd bedt NIFU STEP om å intervjue to informanter fra hvert av landenes forskningsbevilgende råd og myndigheter (forskningsråd og departementer) som del av informasjonsgrunnlaget for å kunne vurdere nærmere mulighetene for et nordisk utdanningsforsknings- og formidlingsinitiativ. I dette avsluttende kapittelet skal vi på basis av den foregående gjennomgangen i kapitlene 2, 3, og 4 samt disse intervjuene, diskutere tre forhold nærmere:

- Eventuelle styrkeposisjoner i nordisk utdanningsforskning, herunder hvilke områder som har potensial for å bli toneangivende innen dette feltet i Norden, samt om det eksisterer forskningsområder som kan egne seg til en eventuell felles innsats

- Mulige tiltak som kan identifiseres når det gjelder forskningsformidling på et nordisk nivå, og som kan gi en merverdi for de nordiske land 
- Hvilke modeller kan identifiseres som hensiktsmessige hvis et nordisk initiativ på utdanningsforsknings- og formidlingsfeltet initieres

\subsection{Mulighetsrommet innenfor nordisk utdanningsforskning}

Som vi har vist i de foregående kapitler er utdanningsforskning i Norden svært mangfoldig. Særlig i det siste tiåret har man sett at forskningsfeltet er i endring både tematisk og når det gjelder hvilke fagfelt og perspektiver som forskningen tar i bruk. Fremdeles er forskningen i stor grad dominert av mindre prosjekter, gjerne initiert og utført av enkeltpersoner, og som har begrenset spredning utover lokal og allmennrettet formidling. Den nordiske utdanningsforskningen involverer videre en rekke ulike fagfelt som søker å besvare spørsmål som har både mer anvendt og mer grunnforskningskarakter, og som relateres til ulike nivåer og sektorer i et utdanningsløp. Selv ut fra vårt begrensede datamateriale synes det derfor å være grunn til å poengtere at de beskrivelser som tidligere er gjort av norsk og svensk pedagogisk og utdanningsvitenskaplig forskning som både tematisk og fagmessig brede (Norges Forskningsråd 2005: 128; Askling 2006: 135), også er en beskrivelse som synes å være gyldig for de øvrige nordiske land.

Fordi kjennetegnene ved forskningen først og fremst er variasjon og bredde, er en konsekvens at det ikke bare er ett, men mange mulighetsrom for nordisk utdanningsforskning. Behovene og ambisjonene for de tematiske områdene innenfor utdanningsforskningen er høyst forskjellige. Mens enkelte områder har en lang historie og gjerne er orientert mot forskjellige nasjonale og lokale agendaer, er andre av nyere karakter og har en orientering som er mer internasjonal enn eksplisitt nordisk.

Hva som er nordiske styrkeposisjoner, og hvordan dette begrepet skal forstås, kan på denne bakgrunn diskuteres. Etableringen av NordForsk i 2005 som et forskningskoordinerende og forskningsfinansierende organ for forskning der de nordiske land er ledende internasjonalt, kan forstås som at nordisk styrke er synonymt med en satsning på kvalitet og «excellence». Samtidig har Nordisk ministerråd også i andre sammenhenger diskutert dette temaet, og identifisert flere nordiske kulturtrekk som fortolkes som styrker i den nordiske regionen (Nordisk ministerråd 2005: 62). Av elementer som er særlig aktuelle her kan nevnes likhet, tillit, lav maktdistanse, fleksibilitet og inklusjon - elementer som alle kan koples tett til både utdanningssektoren og utdanningsforskningen.

Således er det interessant at mange av våre informanter i høy grad mente at nordisk utdanningsforskning nettopp har en felles orientering mot slike verdier, og at mye av forskningen er tett koplet til disse verdiene, enten som uavhengige eller avhengige variabler. I denne forbindelse mente mange at koblingen mellom skole og utdanningssektoren og velferdsstatens utvikling utgjør en sentral kjerne og distinkt kjennetegn ved 
utdanningsforskning i Norden. Utfordringen i denne forbindelse er imidlertid at mye av denne forskningen synes å være fragmentert, og lite synlig utenfor det nordiske rom.

På den annen side har mange av de mer internasjonale temaer som utdanningsforskning i Norden har tatt for seg i de seneste årene, herunder bruk av ny teknologi/IKT, studier av høyere utdanning, forskning på læring hos barn i førskolealder, de sosiokulturelle betingelsene for læring, fagdidaktikk, etc., i mindre grad de nevnte verdier som et eksplisitt utgangspunkt, selv om de i høyeste grad kan koples til disse verdiene. Det man her kan synes å stå overfor er et generasjonsskifte innen utdanningsforskningen, hvor yngre forskere både innenfor og utenfor et pedagogisk ståsted bidrar til å utvide interessefeltet for forskningen. At den nye generasjonen gjerne er mer synlig utenfor Norden gjennom en mer aktiv internasjonal publisering betyr at man står overfor det paradoks at den forskning som verdimessig kanskje i størst grad kan forbindes med Norden er mindre synlig internasjonalt, mens man markerer seg mer på tematiske felter hvor den nordiske dimensjon er mindre tydelig.

Det er derfor mange argumenter som taler for et nordisk initiativ på utdanningsforsknings- og formidlingsfeltet. Utdanningsforskning i Norden bygger på et felles verdigrunnlag, man kan identifisere en del identiske utfordringer knyttet til utdanningssystemenes funksjonalitet, mye av forskningen er lokal, i tillegg synes samarbeid mellom forskere i dag å skje like mye utenfor den nordiske kontekst som innenfor. Til sammen tyder dette på at større grad av samarbeid og en økt grad av koordinering på dette feltet kan gi en nordisk merverdi på en rekke områder.

Samtidig kan vurderinger av styrkeposisjoner på denne bakgrunn vinkles på flere måter. For det første kan det argumenteres for at de verdier som forbindes med den nordiske region står så sterkt at et eventuelt utdanningsforskningsinitiativ bør koples til dette. For det andre kan man også påpeke at $\mathrm{i}$ et utdanningspolitisk landskap som endres hurtig bør forskning som allerede har et internasjonalt tilsnitt og er internasjonalt ledende, prioriteres over annen forskning. For det tredje kan man argumentere med at man her ikke står overfor et enten - eller. Det hører inn under et fremtidig mulighetsrom å etablere forbindelseslinjer mellom den økende tematiske bredde, de mange nye faglige tilnærminger som brukes, og den yngre generasjon av forskere som kommer til. Dette er prinsipielle spørsmål som bør avklares svcert tidlig i en diskusjon om en eventuell nordisk satsning på utdanningsforskning. (se også tabell 5.1).

Tabell 5.1: Mulige forståelser av «nordisk styrke»

\begin{tabular}{lll}
\hline & \multicolumn{1}{c}{ Kvalitet og relevans i forskningen } \\
\cline { 3 - 3 } & & Lav Høy \\
\hline $\begin{array}{l}\text { Forskningen avspeiler } \\
\text { nordiske verdier }\end{array}$ & $\mathrm{Ja}$ & \\
\cline { 3 - 3 } & $\mathrm{Nei}$ & \\
\hline
\end{tabular}


De tre alternativer som her skisseres vil imidlertid ha kjennetegn som tilsier at innretningen på de initiativ som tas bør være relativt forskjellige. Hvis man eksempelvis ønsker et initiativ der utdanningsforskning skal koples til de nordiske verdier som ble skissert over, vil det relativt fragmenterte forskningsfeltet det her er snakk om tilsi at et første skritt bør være å kople ulike aktører, institusjoner og temaområder i større og mer komparative nettverksbaserte forskningssatsninger for derigjennom å styrke kvaliteten. Ønsker man et fokus på forskning som allerede er internasjonal, vil en ytterligere styrkning av formidlings- og spredningsaspektene være det sentrale, mens det tredje alternativet tilsier mer tematisk styrte forskningssatsninger der ønsket om sterkere forbindelseslinjer mellom de nordiske verdier og de nye forskningsområdene konkretiseres som eksplisitt styringsstrategi. Disse eksemplene synliggjør også at man innenfor utdanningsforskningsområdet kanskje må se eventuelle utdanningsforsknings- og formidlingsinitiativ mer i helhet, og ikke betrakte dette som to atskilte prosesser.

Basert på det forhold at en eventuell satsning på utdanningsforskning $\mathrm{i}$ nordisk regi både trenger å initieres forholdsvis raskt, og sannsynligvis også vil ha begrenset med ressurser tilgjengelig, kan det argumenteres for at en slik satsning i første omgang bør konsentreres om forskning som allerede har høy kvalitet og eventuelt som kan utfylles med en komparativ dimensjon mellom landene eller mellom nordiske og andre land. I den grad slik forskning også kan koples til et nordisk verdigrunnlag, kan det eventuelt inngå som en viktig selekteringsmekanisme.

\subsection{Forskning og formidling - mangfoldige behov}

En prioritering av forskning som allerede har høy kvalitet, medfører at formidlingsaspektet i en slik satsning blir sentralt, gjerne formidling med et sterkt komparativt tilsnitt. Som vår gjennomgang av utdanningsforskningen viser i kapittel 2, 3 og 4, er det betydelige utfordringer knyttet til dette. Selv om forskningsaktiviteten og -produksjonen innen utdanningsforskningen har økt markant i alle nordiske land de siste tiårene, er feltet som sådan vanskelig å få en oversikt over siden de akademiske møtestedene er mange, fordi fagfeltene involvert øker i antall, fordi feltet har et mangfoldig empirisk nedslagsfelt, og fordi publisering og rapportering skjer i en rekke forskjellige kanaler.

Denne situasjonen kan antyde behovet for tre typer grep. For det første; situasjonen skaper en usikkerhet knyttet til hvor man skal lete for å finne relevant forskning om et spesielt emne. Slik sett er det grunn til å etterlyse mer informasjon og formidling om de aktiviteter som faktisk foregår, der en mer detaljert og løpende kartlegging av utdanningsforskning kan være ønskelig. For det andre; det kan stilles spørsmål ved hvorvidt en kartlegging i seg selv vil gi en merverdi siden denne prosessen 
bare samler og systematiserer forskningen, og ikke går inn i den for å vurdere og/eller systematisere de resultater som forskningen frembringer. En slik prosess ville eventuelt bære preg av «clearinghouse»/metavurdering av forskningsaktiviteten, og vil kunne innebære stor merverdi for de nordiske land (og eventuelt andre land). For det tredje; ved hjelp av ulike metavurderinger vil man kunne gi viktige impulser tilbake til forskningen, og denne formen for systematisk formidling kan ses på som et viktig element i initiering av ny forskning.

Denne tankegangen er på fremmarsj også internasjonalt, og med oppblomstring av en mer kvantitativt orientert «metavurderingsindustri» både innen helse- og utdanningsfeltet, og etableringen av ulike former for metodikk som er ment spesielt for ulike former for metavurdering av forskning (systematic reviews). Svakheten ved slike opplegg er imidlertid at dette primært representerer en politisk administrativ relevans-tenking, og ikke hensynet til forskningsfeltets faglige kvalitet og autonomi. Et annet eksempel er den økende interesse som man i dag ser for å kunne måle og konkretisere effektene av utdanning, både på individ og samfunnsnivå. Debattene om «learning outcomes», «value added» og «evidence-based policy-making» kretser alle rundt hva som er kunnskapsstatus innen ulike fagfelt, og en antydning om at man politisk i økende grad interesserer seg for resultatene av de ressurser utdanningssektoren får tildelt. Det nylig initierte AHELO-prosjektet (Assessing Higher Education Learning Outcomes) i OECD, og ikke minst de velkjente PISA-studiene er eksempler på det samme.

I Norden har det i alle land vært tatt ulike initiativ på dette feltet, men samtidig kan det argumenteres for at et fokus på Norden i seg selv kan være verdifullt. Det forhold at man mener å kunne se noen felles nordiske verdier som er nedfelt i landene i regionen, kan også bety at utdanningssystemene kan ha en del kulturelle og verdimessige fellestrekk som skiller dem fra andre regioner, og som det kan være viktig å systematisere. Som antydet kan et slikt tiltak også vœre med å bygge ned skillet mellom forskning og formidling. Det faktum at en god del av forskningen på feltet er tett koplet til praksisfeltet støtter også opp under en tenkning der det skarpe skillet mellom forskning og formidling må brytes ned. Når forskning involverer praksisfeltet betyr det ofte at formidling bygges inn som en del av forskningsprosessen, slik det for eksempel var stilt krav om i programmet Praksis-FoU i Norges forskningsråd (se kap 3 og Borgen m. fl. 2009).

Samtidig betyr imidlertid ikke dette at mer ordinær formidlingsvirksomhet nedvurderes. Som vist i vår begrensede kartlegging synes det fremdeles å være mye forskning som formidles i det man kan kalle «grå litteratur» - konferansepapers, ulike rapporter og i form av formidling i ikke-fagfellevurderte kanaler. Her kan det tenkes ulike initiativ for å få denne forskningsformidlingen løftet inn i mer etablerte, formelle og åpne kanaler. Dette kan gjøres gjennom støtte til etablering av nye kanaler, og eventuelt at forskningsmiljøer som har et mer teoretisk ut- 
gangspunkt også kan få formidlet sine resultater i større grad til både politikk og praksisfeltet.

Som et eksempel er det under skissert en enkel tabell som illustrerer hvilket mulighetsrom Nordisk ministerråd har på utdanningsforskningsfeltet gitt de ulike kjennetegnene ved nordisk utdanningsforskning. Tabellen tar ikke hensyn til hva slags organisatoriske løsninger de ulike tiltak krever, ei heller hva slags tematisk fokus som konkret skal prioriteres. Den er først og fremst ment som en illustrasjon på den «meny» av tiltak som eksisterer i forhold til ulike stadier i forskningsprosessen. Tabellen illustrerer også at en eventuell satsning på nordisk utdanningsforskning krever en relativt høy grad av tilpasning til den situasjon det enkelte tematiske forskningsområde er i.

Tabell 5.2: Eksempler på tiltak for å styrke nordisk utdanningsforskning

\begin{tabular}{|c|c|c|c|}
\hline \multirow[b]{2}{*}{$\begin{array}{l}\text { Kjennetegn ved ulike } \\
\text { forskningsfelt }\end{array}$} & \multicolumn{3}{|c|}{ Mulighetsrommet for tiltak etter de ulike stadiene i forskningsprosessen } \\
\hline & $\begin{array}{l}\text { Formål, program, } \\
\text { initiering }\end{array}$ & $\begin{array}{l}\text { Forskningsprosessen, } \\
\text { forskningspraksis }\end{array}$ & Resultat, formidling \\
\hline $\begin{array}{l}\text { Eksempel 1: } \\
\text { Tematisk bredt felt, } \\
\text { mange aktører, prak- } \\
\text { sisnært, lokal oriente- } \\
\text { ring, begrenset spred- } \\
\text { ning }\end{array}$ & $\begin{array}{l}\text { Behov for integrering } \\
\text { av aktører, felles } \\
\text { arenaer, nettverks- } \\
\text { satsninger }\end{array}$ & $\begin{array}{l}\text { Behov for teoribygging, } \\
\text { samarbeid mellom } \\
\text { nasjonale forskerskoler } \\
\text { (jfr. aktiviteten i Nord- } \\
\text { Forsk på dette feltet), } \\
\text { nye forskningsprogram }\end{array}$ & $\begin{array}{l}\text { Behov for økt spred- } \\
\text { ning - etablering av et } \\
\text { nettsted med oversikt } \\
\text { over nordiske forsk- } \\
\text { ningsinitiativ, artikkel- } \\
\text { samlinger, bøker }\end{array}$ \\
\hline $\begin{array}{l}\text { Eksempel 2: } \\
\text { Tematisk bredt felt, } \\
\text { mange aktører, teore- } \\
\text { tisk, internasjonale } \\
\text { relasjoner, varierende } \\
\text { spredning }\end{array}$ & $\begin{array}{l}\text { Behov for integrering } \\
\text { av perspektiver, } \\
\text { forskerseminarer, } \\
\text { seminarer mellom } \\
\text { brukere og forskere }\end{array}$ & $\begin{array}{l}\text { Behov for kunnskaps- } \\
\text { oversikter/«reviews», } \\
\text { komparative studier, } \\
\text { sammenligninger på } \\
\text { tvers av land }\end{array}$ & $\begin{array}{l}\text { Behov for mer foku- } \\
\text { sert spredning - } \\
\text { gjerne i fagfelle- } \\
\text { vurderte tidsskrift også } \\
\text { utenom Norden }\end{array}$ \\
\hline $\begin{array}{l}\text { Eksempel 3: } \\
\text { Tematisk smalt felt, } \\
\text { færre aktører, teore- } \\
\text { tisk, internasjonalt } \\
\text { fokus, høy spredning }\end{array}$ & $\begin{array}{l}\text { Behov for konsolide- } \\
\text { ring, } \\
\text { dr.gradssatsninger, } \\
\text { miljøstøtte til lære- } \\
\text { steder som har } \\
\text { demonstrert høy } \\
\text { kvalitet i forskningen }\end{array}$ & $\begin{array}{l}\text { Behov for å skape } \\
\text { etablerte nettverk for } \\
\text { forskerne på feltet (jfr. } \\
\text { Nettverk for nasjonale } \\
\text { CoE støttet av Nord- } \\
\text { Forsk) }\end{array}$ & $\begin{array}{l}\text { Behov for å styrke } \\
\text { policyimplikasjonene } \\
\text { av forskningen gjen- } \\
\text { nom egne policytunge } \\
\text { brukerseminarer, } \\
\text { nordiske konferanser }\end{array}$ \\
\hline
\end{tabular}

Når det gjelder eksempel 1: Tematisk bredt felt, mange aktører, praksisnært, lokal orientering, begrenset spredning, kan et eksempel være forskningen på grunnopplæringen som beskrives som mangfoldig, kvalitativ småskala forskning men som gjerne gjenspeiler et nordisk elevsyn. Denne forskningen er lite synlig både nordisk og internasjonalt, men har tematiske nettverk, for eksempel innenfor NFPF (se kap. 4). Et annet eksempel kan være førskolestudier som kan se ut til å ha små miljøer eller enkeltforskere som publiserer internasjonalt. Et tredje eksempel er lærerutdanning/profesjonsutdanning hvor det kan sies å være mange aktører som forsker nær praksisfeltet, og hvor det kan være nordiske særtrekk knyttet til forståelsen av lærer/elevrelasjonen, men som synes spredt og med lite kummulativ kunnskapsutvikling. 
Når det gjelder eksempel 2: Tematisk bredt felt, mange aktører, teoretisk, internasjonale relasjoner, varierende spredning, kan et eksempel være allmenndidaktikk og fagdidaktikk. Der har det over årene foregått praksisnær forskning innenfor mange fagdisipliner og blant mange aktører. Miljøene er imidlertid til dels små og spredte, og forskningen formidles først og fremst gjennom nettverk mellom enkeltforskerne nasjonalt og nordisk. Særlig fagdidaktikken innenfor naturfagene og matematikk er blitt internasjonalt orientert som følge av PISA-studiene, men også for eksempel leseforskning har internasjonal orientering. Likevel får vi et inntrykk av at for lite av den fagdidaktiske forskningen i Norden er blitt publisert internasjonalt og derfor ikke har fått den posisjonen den kunne hatt.

Når det gjelder eksempel 3: Tematisk smalt felt, færre aktører, teoretisk, internasjonalt fokus, høy spredning, kan dette være nordisk forskning med sosiokulturelt perspektiv på læring, der det fins forskning som er godt internasjonalt etablert men som ikke i samme grad er tilbakeført i forhold til praksis og i forhold til politikkutformingen. Et annet eksempel er kunnskapsosiologisk forskning, med en åpenbar nordisk styrke som ligger i registerdataene som er unike internasjonalt, men som kanskje er i behov av å kobles tettere til et mer innholdmessig fokus på hva som skjer i praksis i skolehverdagen og strukturelle rammebetingelser for denne praksisen, og hvordan dette på ulike måter eventuelt bidrar til ulikhet som resultat. Her er det dessuten varierende spredning av kunnskapsstatus både i forhold til praksis og i forhold til politikkutformingen.

\subsection{Organisasjons- og finansieringsmodeller}

Når det gjelder forslag til konkrete organisasjons- og finansieringsmodeller, står man overfor ganske store valgmuligheter. Det er ikke slik at bestemte tiltak tilsier bestemte organisasjonsløsninger. Situasjonen kompliseres ytterligere ved at det innenfor utdanningsforskningsfeltet allerede er i gang ulike nasjonale satsninger - enten i form av spesielle forskningsprogram eller i form av å etablere kunnskapsstatus på ulike felt. Gitt ambisjonene om «nordisk merverdi» mener vi at et nordisk initiativ på dette feltet må spille på lag med de nasjonale satsninger som allerede eksisterer, og velge organisasjonsmodeller som vekter balansen mellom «det nordiske» og «det nasjonale» på ulike måter: Under skisseres tre alternative modeller basert på ambisjonsnivå og ressurstilgang:

\section{Modell 1: «Nordisk merverdi» innenfor de nasjonale satsninger}

I denne modellen har nasjonale forskningssatsninger en dominerende plass, og nasjonale forskningsprogrammer er fremdeles knyttet an til de forskningspolitiske agendaer i de enkelte land. Det nordiske perspektiv 
ville i denne modellen kjennetegnes av å være et supplerende initiativ, og kunne innebære:

- At man innen de nasjonale programmer gir incitamenter som styrker den fellesnordiske forskningen gjennom at man tilkjennegir ønsker om komparativ nordisk forskning, og at det etableres støtteordninger på nordisk nivå som kan stimulere til dette - ordninger som eksempelvis kun er åpne for forskere som allerede har fått tildelt forskningsmidler nasjonalt.

- At man på nordisk nivå har midler knyttet til formidling - her vil initiativer tas «bottom-up» der forskerne/forskningsprogrammene selv identifiserer slike tematiske felt, og søker Nordisk ministerråd om støtte.

De økonomiske rammene er i denne modellen begrenset, gjerne mer relatert til formidling og systematisering, og der man kan tenke seg at bevilgninger på mellom 4-6 millioner i året ville være tilstrekkelig.

\section{Modell 2: Et nordisk perspektiv inspirerer nasjonale satsninger}

I denne modellen kan det tenkes at man etablerer spesielle forskningssatsninger på et nordisk nivå, men der tilslag på slike midler er knyttet opp til nasjonal medfinansiering. Dette er en modell som eksempelvis European Science Foundation også bruker. Utgangspunktet er her at man på nordisk nivå klarer å utmeisle forskningssatsninger som man også vurderer som interessante i det enkelte land. Modellen forutsetter ikke deltakelse fra alle de nordiske land, men man kunne tenke seg at støtte er betinget av deltakelse fra minst tre av landene. Denne modellen er i stor grad kjennetegnet av forhandling mellom det nordiske og det nasjonale nivå, og kunne innebære:

- At man på nordisk nivå initierer større komparative forskningsprosjekter på spesielle tematiske områder, dog uten at forskningen «styres» i et nordisk perspektiv

- At man på nordisk nivå etablerer en organisatorisk kapasitet til å «overvåke» nasjonale initiativ som kan ha en «nordisk dimensjon», og hvor man har ressurser tilgjengelig til å «oppgradere» disse i større nordiske satsninger.

Denne modellen tilsier en noe større økonomisk ramme, ikke minst knyttet opp til etablering av en overvåknings- og en basisfinansieringsmekanisme. En bevilgning på mellom 8-12 millioner kroner årlig kan her være realistisk i forhold til et slikt ambisjonsnivå. 


\section{Modell 3: En nordisk koordinering av nasjonale satsninger}

I denne modellen tenkes det nordiske nivået som langt mer aktivt i forhold til forskningsinitiering- og styring. Her kan ikke minst NordForsk tenkes å spille en veldig sentral rolle når det gjelder å fremme forskningssatsninger innenfor utdanningsforskning som kan være innovative og mer fremtidsrettede i forhold til de felles utfordringer utdanningssektoren i Norden står overfor. Denne modellen kjennetegnes av en proaktiv holdning til utdanningsforskningsfeltet, og kunne innebære:

- At man etablerer egne nordiske forskningsprogrammer og/eller formidlingsinitiativ på felter hvor man ut fra et nordisk perspektiv mener å kunne se merverdier i forhold til der hvor man eventuelt kan identifisere lite og/eller svak forskning; der hvor man mener Norden som region kan ha spesielle fortrinn; eller som en videreutvikling av felter hvor man allerede har sterke miljøer

- At man kan bruke ressurser på institusjons- og miljøstøtte der flere institusjoner sammen blir tillagt et særlig ansvar for å ivareta et spesielt felt, og for å bygge en mer koordinert nordisk forskningsinnsats.

Denne siste modellen er langt mer ambisiøs enn de foregående, og tilsier også en ramme på mellom 16-20 millioner årlig for å kunne satse mer systematisk på noen flere felt samtidig.

Som antydet over er modellene som skisseres kjennetegnet av ulikt ambisjonsnivå. Mens modell 1 ikke fraviker vesentlig fra tiltak og støtteordninger Nordisk ministerråd har iverksatt på andre felt, innebærer modell 2 også en utbygging av et noe større apparat til overvåkning og «prosesstimulering» i det nordiske rom, mens modell 3 har forholdsvis omfattende samarbeids,- ressurs- og organiseringsimplikasjoner. Men som understreket tidligere, kan altså tiltakene som vi har skissert i tabell 5.2 variere mer, og kan være aktuelle i flere av modellene.

\subsection{Noen forslag til konkrete tematiske prioriteringer}

Som vist over er det et forholdsvis stort politisk handlingsrom knyttet til en fremtidig nordisk satsning på utdanningforskning. Skal man i første omgang prioritere forskning av høy kvalitet som gjerne kan bygges ut med et komparativt tilsnitt, synes vår kartlegging av aktiviteten i Norden å peke på en del konkrete felt hvor det både faglig og politisk kan skapes stor nordisk merverdi:

Forslag 1) De nordiske PISA-funnene har bidratt til diskusjoner om hva slags kunnskapssyn disse funnene gjenspeiler, og hvorvidt de nordiske velferdssamfunn representerer noen særtrekk som kan bidra til å forklare resultatene (se f eks Matti 2009). Hva som er forholdet mellom de 
nordiske PISA-funnene og de «uforklarte» sammenhengene der, er foreslått koblet til antagelsen om at det finnes en «nordisk undervisningskultur», en «nordisk diaktikk», et «nordisk elevsyn» osv. Samtidig har forskjellene mellom PISA-resultatene i de nordiske landene ført til en jakt på det spesielle ved Finland (jfr. TemaNord 2009). I kapittel 2, 3, og 4 er det pekt på noen trekk som kan være verd å se nærmere på i denne sammenhengen, for eksempel at det i Finland ser ut til å være lavt spenningsnivå mellom pedagogikk som fagdisiplin og lærerutdanningen, at forskerne er tett på praksisfeltet gjennom tematisk innretning, aksjonsforskning, nasjonale møteplasser etc., alt kombinert med forholdsvis stor frihet i forhold til politikkutformingen. En mulig antagelse kan på denne bakgrunn være at slike forhold til sammen bidrar til tett kobling mellom kvalitetsog relevansvurderingene i finsk utdanning. At strukturelle og diskursive forhold kan ha betydning for resultatkvaliteten i opplæringen er i så fall noe som ut fra et argument om nordisk merverdi kunne fortjene å bli gjort til gjenstand for forskningsinnsats.

Samtidig etterlyses det blant informantene for denne studien et nordisk «Beyond-PISA»-initiativ som kan bringe diskusjonene et steg videre når det gjelder forskningsbasert kunnskap og forståelse av sammenhengene i opplæringen som bidrar til elevenes læringsutbytte. Her kan det skapes nordisk merverdi både gjennom komparasjoner mellom landene, men også gjennom en mer ambisiøs forskningsinnsats som tar sikte på å gå «beyond PISA».

Forslag 2) Et område som ut fra kapittel 2 kan synes å representere en sterk nordisk spesialisering og som synes å være sterkt fremme internasjonalt, er studier av ny teknologi i læringssammenheng, herunder bruk av IKT. Når det gjelder IKT i opplæringen har tidligere studier vist at dette er tett koblet til kulturelle og nasjonale særtrekk i europeiske land (Borgen m. fl. 2002). Teknologi og IKT har imidlertid ikke vært en særlig satsning innenfor de enkelte landenes forskningsprogrammer (se kap. 3), og har heller ikke vært tematisert av informantene for dette prosjektet (se kap. 4). Samtidig kan det observeres at i utdanningspolitiske sammenhenger både i Norden og internasjonalt er teknologi og IKT gitt mange ressurser og ofte koblet til høyt aktuelle tema som innovasjon og entreprenørskap i og i tilknytning til utdanning (jfr. at Nordisk ministerråd (NMR) i 2009-2010 gjennomfører en nordisk komparativ studie om kreativitet, innovasjon og entreprenørskap i utdanningen). Tatt i betraktning at de ulike nordiske landene har valgt svært ulike strategier for hvilken plass og ressurser teknologi og IKT får i opplæringen, kan dette være et interessant område for komparative studier i Norden og i forhold til andre land, og noe som kan skape nordisk merverdi.

Forslag 3) Innen høyere utdanning er det skjedd store endringer i Norden det siste tiåret. Bolognainspirerte reformer og nasjonale strukturelle endringer knyttet til den økende betydningen av globalisering i sektoren, er noen stikkord som beskriver drivkreftene i denne utviklingen. Selv om 
utfordringene i høy grad er like i nordiske land, synes imidlertid de ulike land å ha ulike svar på utfordringene. Nordisk forskning på høyere utdanning er ifølge kapittel 2 svært synlig internasjonalt. Dette feltet peker seg derfor ut som et aktuelt felt for å styrke den nordiske dimensjonen, gjennom at det tas initiativ til større grad av sammenligninger og komparative prosjekt.

Sentrale stikkord for prosjekter innen dette feltet er: effekter av sammenslåinger i høyere utdanning; utvikling av institusjonelle faglige profiler ved de ulike universitet og høyskoler; økt kunnskap om samarbeid mellom universitet og næringsliv i de ulike landene. Ut fra at det eksisterer mye nasjonal forskning på disse feltene, kan et prosjekt i første omgang være å gjøre en mer systematisk kunnskapsoversikt over denne, alternativt at man bevilger ressurser til et komparativt prosjekt.

Forslag 4) Lærerutdanningen i de nordiske landene har nylig vært gjenstand for komparative studier etter initiativ fra Nordisk ministerråd (TemaNord 2009:505). Der foreligger allerede analyser og anbefalinger angående tema som kan følges opp gjennom mer målrettede studier. De endringene i lærerutdanningene som det er redegjort for i denne rapportens kapittel 4, kan imidlertid bidra med nye og fruktbare perspektiver på den nordiske dimensjonen. Dette gjelder for eksempel de nye rammebetingelser og organiseringsformer ved lærestedene når universiteter og lærerutdanningsinstitusjoner blir slått sammen, hvordan de ulike landenes tradisjoner når det gjelder forholdet mellom lærerutdanningene og pedagogikkfaget har satt spor, og hvordan forholdet til forskning og det bredere utdanningsvitenskapelige feltet er i bevegelse i landene.

Avslutningsvis vil vi påpeke at alle forslagene i dette kapitlet er tentative og ment som grunnlag for videre diskusjon. De er her derfor heller ikke rangert eller koblet direkte til de finansielle strukturene som det nordiske forskningssamarbeidet er innrammet av. 



\section{Referanser}

Aasen, P., Prøitz, Tine S. (2004): Initiering, finansiering och förvaltning av praxisnära forskning Sektormyndighetens roll i svensk utbildningsforskning. Oslo: NIFU Skriftserie 10/2004.

Aasen, P., Prøitz, Tine Sophie, Borgen, Jorunn Spord (2005). Utdanningsvitenskap som kunnskapsområde. En studie av Vetenskapsrådets støtte til utdanningsvitenskapelig forskning. Stockholm: Vetenskapsrådets rapportserie 5/2005.

Aasen, P., Sandberg, Nina, Borgen, Jorunn Spord (2007). Utdanningsforskning. Fagdepartementets sektorforskningsansvar. Oslo, NIFU STEP Rapport nr 15/2007.

Askling, B. (2006): Utbildningsvetenskap - ett vetenskapsområde tar form. Stockholm: Vetenskapsrådets rapportserie R16:2006.

Bergem, T., Björkqvist, O., Hansén, S-E., Carlgren, I. \& Hauge, T. (1997): Research on teachers and teacher education in Scandinavia: a retrospective view. Scandinavian Journal of Education, 41, pp. 433-458.

Besley, T. (ed.) (2009): Assessing the quality of educational research in higher education. International perspectives. Rotterdam: Sense publishers.

Borgen, J. S., Vibeke Opheim, Tine Sophie P. (2009): PraksisFoU 20052010. Vurdering av forskningsprogrammet Praksisrettet FoU for barnehagen, grunnopplæringen og lærerutdanningen. Oslo: NIFU STEP Rapport 25/2009.

Borgen, J. S., Terje Bruen Olsen, Petter Aasen (2008): Karriereveier for forskere i UVK. Oslo: NIFU STEP Rapport 36/2008.

Borgen, J. S., Hebe Gunnes, Gunnar Sivertsen (2007). Kartlegging av norsk utdanningsforskning. Oslo: NIFU STEP Rapport nr. 32, 2007.

Borgen, J. S., Peter Fehér, Silvia Ferrero, Andrea Karpati, Christos Ioannides, Kirsten Klaebo, Fran Payne, Serge
Pouts-Lajus, Mary Simpson, Stella Vosniadou (2002). Observation and Analysis of the Uses of Information and Communication Technology in European Primary and Secondary Schools - An Intercultural Approach. Final Report. Paris/EU, Socrates-Minierva prosjekt no. 88093-CP-1-2000-1-FR-Minerva-ODL.

Englund, T. (2004): Nya tendenser inom pedagogikdisciplinen under de tre senaste decennierna. I: Pedagogisk Forskning i Sverige 2004 årg 9 nr 1 s 37-49. Göteborg: Göteborg Universitet, Institutionen för pedagogikk och didaktik.

Gunnes, H. (2007): Ressursinnsatsen innenfor utdanningsforskning 2007. Oslo: NIFU STEP 16/2009.

Hansen, Michael \& Lindblad, Sverker (2009): Svensk utbildningsvetenskaplig forskning: Om forskningskommunikation och publiceringsmönster vid tre lärosäten. Göteborgs universitet

Högskoleverket (2005a): Utvärdering av den nya lärarutbildningen vid svenska universitet och högskolor. Del 1. Reformuppföljning och kvalitetsbedömning. Stockholm: Högskoleverket Rapport 2005/17R.

Högskoleverket (2005b): Utvärdering av grund- og och forskarutbildning innom ämnesområdene pedagogikk, didaktik och pedagogisk arbete vid svenska universitet och högskolor. Del 1: Allmänna avsnitt. Stockholm: Högskoleverket Rapport 2005/19R.

Kunnskapsdepartementet (2008): Kunnskapsdepartementets strategi for utdanningsforskning. Kunnskap for kvalitet 2008-2013. Oslo: Kunnskapsdepartementet.

Lindberg, L. (2002): Is «Pedagogik» as an Academic Discipline in Sweden just a Phenomenon for the Twentieth Century? The Effects of Recent Education Reform. In: European Educational Research Journal, Volume 1, November 1, 2002.

Danmarks lærerhøjskole. Historie, opgaver og virksomhed. Lest 29.10.2009 på 
adressen: http://www.dpu.dk/everest/ Publications/Nyheder/2006/ 20061109101803/CurrentVersion/DLH hist.pdf

Nordisk ministerråd (2009): Komparativt studium af de nordiske læreruddannelser. København: Nordisk Ministerråd, TemaNord 2009:505.

Norges forskningsråd (2005): Norsk pedagogisk forskning. En evaluering av forskningen ved utvalgte universiteter og høgskoler. Oslo: Norges Forskningsråd.

Macdonald, A., Kaldalóns, I. \& Jónasson, J. T. (2005): Tension and slippage: the status and impact of educational research in Iceland. Perth: Scottish Educational Research Association Annual Conference (November).

MR-U:s strategi for utdannings- og forskningsområdet 2008-2010: Norden en ledende, dynamisk kunnskaps och kompetanseregion. København.

Matti, T. (Eds.) (2009): Northern Lights on PISA 2006. Differences and simi- larities in the Nordic countries. Copenhagen: Nordic Council of Ministers, TemaNord 2009:547.

OECD/CERI (2004): National Review on Educational R \& D. Examiners' Report on Denmark. Paris: OECD.

Petersen, L. (1994): Skole på Færøyene i 1000 år. Torshavn: Estra, Gøta.

Rannis/Icelandic Centre for Research and Ministry of Education, Science and Culture (2005): An evaluation of educational research and development in Iceland (Summary). Reykjavik: Rannis.

Sivertsen, G. (2007): Bibliometri for svensk utdanningsvitenskap. Et pilotprosjekt. Stockholm: Vetenskapsrådet.

Vislie, L. (2002): Evalueringen av norsk pedagogisk forskning 2002. Bakgrunnsnotat. Oslo: Norges forskningsråd.

Westbury, I., Hansén, S-E., Kansanen, P. \& Björkqvist (2005): Teacher education for research-based practise in expanded roles: Finland's experience. Scandinavian Journal of Education, 49, pp. 475-485. 


\section{Summary}

In 2009, the Nordic Council of Ministers (NCM) commissioned a study of Nordic educational research and the dissemination of its results. The study was conducted by the Norwegian Institute for Studies in Innovation, Research and Education (NIFU STEP) and Technopolis, and forms part of the NCM's evaluation of whether to instigate further expansion of research and education co-operation (cf. the plan for the research, culture and education sector in the programme for the Icelandic Presidency of the NCM 2009). The primary objective was to assess the potential for a joint Nordic initiative by conducting a mapping exercise of current and planned initiatives in the various countries and autonomous territories, as well as to consult stakeholders about relevant areas and forms. The study builds on quantitative (bibliographical) and qualitative data, including a series of interviews with researchers, decision-makers and individuals employed by research-funding bodies in the Nordic countries. A mapping exercise (literature survey) was also conducted of political and national initiatives in the period 2004-2008.

The bibliographical data and interviews with key researchers revealed great diversity in terms of disciplines, perspectives, research focus, methodology, and the publication and dissemination of research results. This makes it difficult to define and delineate educational research with any great precision. It was therefore decided that the study should focus on research at the key institutional players, i.e. universities and colleges of further and higher education, as well as their related publishing activities. It is worth noting that the objective was not to review absolutely every example of educational research, but to highlight general trends. Due to gaps in the bibliographical data, caution is advised before applying the findings of this study in educational research. Bearing these reservations in mind, there does seem to be a tendency for the Nordic Region to stand out in international terms in certain areas of educational research, particularly education and technology, higher education and what are known as curriculum studies, as well as research into teaching and learning.

With regard to research in the individual countries, many of the respondents paint a picture of educational research as emerging from teacher training, and report that the development of educational theory and practice as an academic discipline has played an important role in meeting and fulfilling the need for knowledge in the sector. One feature common to several countries seems to be an ambivalent, strained relationship between teacher training and educational theory and practice as an academic discipline. This is due to a range of historical processes that have involved interaction between policy-making and resource deploy- 
ment, the autonomous development of educational and research establishments and, in particular, divergent individual viewpoints. In addition, developments in the research field in recent years indicate that Nordic educational research has been characterised by changes in policy-making and priorities - as reflected, for example, in greater interest in the various programmes set up to fund educational research in the Nordic Region. One notable consequence is a greater breadth of focus in educational research, which is now more inter-sectoral, inter-disciplinary and multidisciplinary, and is conducted in all areas of society and with a lifelonglearning perspective. A number of programmes can be said to have played a strong role in this development.

The very variety and breadth of Nordic educational research means that there are numerous opportunities for Nordic initiatives - and as the various themes' needs and ambitions are so different, these potential initiatives could be implemented in a variety of ways. While certain areas have a long history and are often oriented towards national and local agendas, others are more recent and have an international rather than explicitly Nordic perspective. Based on the premise that any Nordic initiative in educational research would be expected to produce tangible outcomes relatively quickly on the basis of limited resources, it might be argued that any such initiative should in the first instance focus primarily on areas of research in which high quality has already been established, and which lend themselves to a comparative assessment of the Nordic countries or of the Nordic Region in relation to other countries.

In this light, the mapping exercise conducted of activity in the Nordic Region indicates a number of areas in which political and academic Nordic synergies could be generated:

- The findings of the Nordic Programme for International Student Assessment (PISA) have generated debate about what type of knowledge these findings actually reflect, and the extent to which the characteristics of the Nordic welfare model help explain the educational outcomes. Scope is believed to exist for wide-ranging analyses "beyond PISA"

- The Nordic Region appears to be at the forefront of studies of new technology in a learning context, including the use of ICT. The individual countries have adopted widely differing strategies with regard to the role of and resources allocated to technology and ICT in education, which makes this an interesting area for comparative study.

- Several Nordic countries have introduced major reforms in higher education in the last decade, but there remain major challenges related to globalisation, knowledge transfer and knowledge development.

- Research into teacher training, specifically the new framework conditions and forms of organisation at teacher-training establishments, and the relationship between the actual training and research into it. 
Finally, it is worth pointing out that all of the proposals are tentative and designed to promote further debate. As a result, they are not ranked in terms of priority or linked directly to the financial structures that govern Nordic research co-operation. In addition, the organisation of any such Nordic initiative would have to be agreed with national authorities. 



\section{Appendiks 1}

\section{Referansegruppens medlemmer}

Danmark

Finn Hauberg Mortensen, professor, Institutleder for nordiske studier og sprogvidenskab, Københavns Universitet.

Finland

Pertti Kansanen, professor emeritus, Helsingfors universitet.

\section{Færøyene}

Firouz Gaini, lektor, Ph.D., Fróðskaparsetur Føroya, Føroya Læraraskúli.

Island

Olafur Proppe, Islands Universitet.

\section{Norge}

Elisabeth Storaas Heggen, Avdelingsdirektør, Avdeling for analyse, internasjonalt arbeid og kompetansepolitikk i Kunnskapsdepartementet.

Sverige

Elisabeth Nihlfors, Huvudsekreterare i Utbildningsvetenskapliga kommittén på Vetenskapsrådet. 



\title{
Appendiks 2
}

\author{
Liste over informanter
}

Danmark

Palle Rasmussen, professor Aalborg Universitet.

Karen Borgnakke, professor, Institut for Medier, Erkendelse og Formidling, Afdeling for Pædagogik, Københavns Universitet.

Per Fibæk Laursen, professor, Danmarks Pædagogiske Universitetsskole, Aarhus Universitet.

Jens Dolin, Instituttleder, Institut for Naturfagenes Didaktik, Københavns Universitet.

Finn Hauberg Mortensen, Instituttleder, Institut for Nordiske Studier og Sprogvidenskab, Københavns Universitet.

Thomas Midtgaard, Seksjonsleder, Programkomiteen for uddannelse og kreativitet, Det strategiske forskningsråd.

Hans Siggaard Jensen, Formand, Programkomiteen for uddannelse og kreativitet, Det strategiske forskningsråd.

\section{Finland}

Armi Mikkola, Undervisningsministeriet.

Hannele Niemi, Vicerektor ved Helsingfors Universitet.

Sven-Erik Hansén, professor ved Åbo Akademi Universitet.

Erno Lehtinen, akademiprofessor ved Turku Universitet.

Jouni Välijärvi, Director of Research Center of Edication vid Jyväskylä Universitet.

Anita Lehikoinen, Director, Ministry of Education.

Riitta Mustonen, Academy of Finland.

\section{Færøyene}

Jóhannes Miðskarð, PhD studerende.

Janus Jensen, undervisningsleder ved Færøenes Lærerhøjskole (Færøenes Universitet).

Gestur Hovgaard, PhD.

Olaus Jespersen, avdelingsleder, Kulturministeriet på Færøyene.

Pauli Nielsen, tidligere rektor ved Færøenes Lærerhøjskole.

Annika Sølverá, Research Council, Farao Iceland.

Kristianna Sjovara, Advisor, Ministry of Education. 


\section{Island}

Allyson Macdonald, professor, Head of doktoral studies, «School of Education» ved Islands Universitet (Háskóli Îslands).

Ingolfur A. Johannesson, professor ved Akureyri Universitet (Háskólinn á Akureyri).

Jon Torfi Jonasson, professor, Deakan (Dean) af «School of Education» Islands Universitet (Háskóli Íslands).

Ragnhildur Bjarnadottir, dosent ved «School of Education» ved Islands Universitet (Háskóli Îslands).

Magnus Lyngdal Magnusson, Head of Research and Deputy Director, Research Council Iceland.

Eirikur Smari Sigurdarson, Senior advisor, Ministry of Education

\section{Norge}

Ane Marte Rasmussen, spesialrådgiver, Divisjon for store satsninger i Norges Forskningsråd.

Kirsti Klette, professor ved Pedagogisk forskningsinstitutt, Universitetet i Oslo og leder av programstyret for Utdanning 2020.

Oddbjørn Raaum, seniorforsker, Frischsenteret.

Ole Johnny Olsen, førsteamanuensis, Sosiologisk Institutt, Universitetet i Bergen.

Marianne Røgeberg, seksjonsleder, Politikk og forskningsfinansiering, NordForsk.

Kari Tonhild Aune, seniorrådgiver, Divisjon for store satsninger i Norges forskningsråd.

Eivind Heder, ekspedisjonssjef, Kunnskapsdepartementet.

\section{Sverige}

Sigbrit Franke, professor, f.d. universitetskansler og sjef for Högskoleverket i Sverige.

Lena Tibell, docent, Institutionen för naturvetenskap och teknik, Linköpings universitet.

Donald Broady, professor ved ILU, Uppsala Universitet.

Staffan Larsson, professor ved Linköpings universitet.

Tomas Englund, professor i pedagogikk, Örebro Universitet.

Rolf Sandahl, särskild utredare, regeringens utredning om utvärdering av utbildning.

Ingela Josefson, rektor, Södertörns högskola.

Ulf P. Lundgren, professor ved Uppsala Universitet.

Pär Omling, generaldirektør, Vetenskapsrådet.

Ann-Sofie Hollsten-Yamamoto, Departementssekreterare.

Forskningspolitiska enheten, Utbildningsdepartementet. 


\section{Appendiks 3}

\section{ISI indexed journals on education}

Table A.3.1: List of ISI indexed journals on education, articles with at least one Nordic address included (2005-2008).

\begin{tabular}{|c|c|}
\hline Title & Number of articles \\
\hline Adult Education Quarterly & 1 \\
\hline Advances In Health Sciences Education & 5 \\
\hline Aids Education And Prevention & 1 \\
\hline Anthropology \& Education Quarterly & 1 \\
\hline Asia Pacific Education Review & 3 \\
\hline British Educational Research Journal & 3 \\
\hline British Journal Of Educational Technology & 15 \\
\hline British Journal Of Sociology Of Education & 7 \\
\hline Comparative Education & 5 \\
\hline Comparative Education Review & 3 \\
\hline Computers \& Education & 20 \\
\hline Early Childhood Research Quarterly & 1 \\
\hline Economics Of Education Review & 8 \\
\hline Educational Gerontology & 2 \\
\hline Educational Leadership & 1 \\
\hline Educational Research & 5 \\
\hline Educational Review & 2 \\
\hline Educational Studies & 7 \\
\hline Educational Technology \& Society & 18 \\
\hline European Physical Education Review & 7 \\
\hline Gender And Education & 15 \\
\hline Health Education Research & 26 \\
\hline Higher Education & 34 \\
\hline Innovations In Education And Teaching International & 3 \\
\hline Interactive Learning Environments & 3 \\
\hline International Journal Of Art \& Design Education & 6 \\
\hline International Journal Of Educational Development & 9 \\
\hline International Journal Of Science Education & 17 \\
\hline Journal For Research In Mathematics Education & 1 \\
\hline Journal Of Computer Assisted Learning & 10 \\
\hline Journal Of Curriculum Studies & 12 \\
\hline Journal Of Economic Education & 1 \\
\hline Journal Of Education Policy & 8 \\
\hline Journal Of Educational And Behavioral Statistics & 1 \\
\hline Journal Of Experimental Education & 1 \\
\hline Journal Of Moral Education & 10 \\
\hline Journal Of Philosophy Of Education & 7 \\
\hline Journal Of Research In Reading & 5 \\
\hline Journal Of Research In Science Teaching & 3 \\
\hline Journal Of School Health & 2 \\
\hline Journal Of Teaching In Physical Education & 1 \\
\hline Journal Of The Learning Sciences & 4 \\
\hline Language Learning & 1 \\
\hline Language Teaching Research & 2 \\
\hline Learning And Instruction & 13 \\
\hline Minerva & 10 \\
\hline Oxford Review Of Education & 2 \\
\hline Paedagogica Historica & 10 \\
\hline Quest & 2 \\
\hline Reading And Writing & 5 \\
\hline Research In Higher Education & 1 \\
\hline Research In Science Education & 7 \\
\hline Review Of Educational Research & 1 \\
\hline Revista Espanola De Pedagogia & 1 \\
\hline
\end{tabular}




\begin{tabular}{lr} 
Title & Number of articles \\
\hline School Effectiveness And School Improvement & 2 \\
Science Education & 6 \\
Scientific Studies Of Reading & 4 \\
Second Language Research & 3 \\
Sociology Of Education & 1 \\
Sport Education And Society & 7 \\
Studies In Higher Education & 23 \\
Teachers College Record & 2 \\
Teaching And Teacher Education & 14 \\
Teaching In Higher Education & 5 \\
Tesol Quarterly & 2 \\
Theory Into Practice & 1 \\
Urban Education & 1 \\
Young Children & 1 \\
Zeitschrift Fur Erziehungswissenschaft & 2 \\
Zeitschrift Fur Padagogik & 2 \\
Zeitschrift Fur Soziologie Der Erziehung Und Sozialisation & 2 \\
Total & 427
\end{tabular}




\section{Appendiks 4}

Nordic authors listed in ISI-indexed journals 


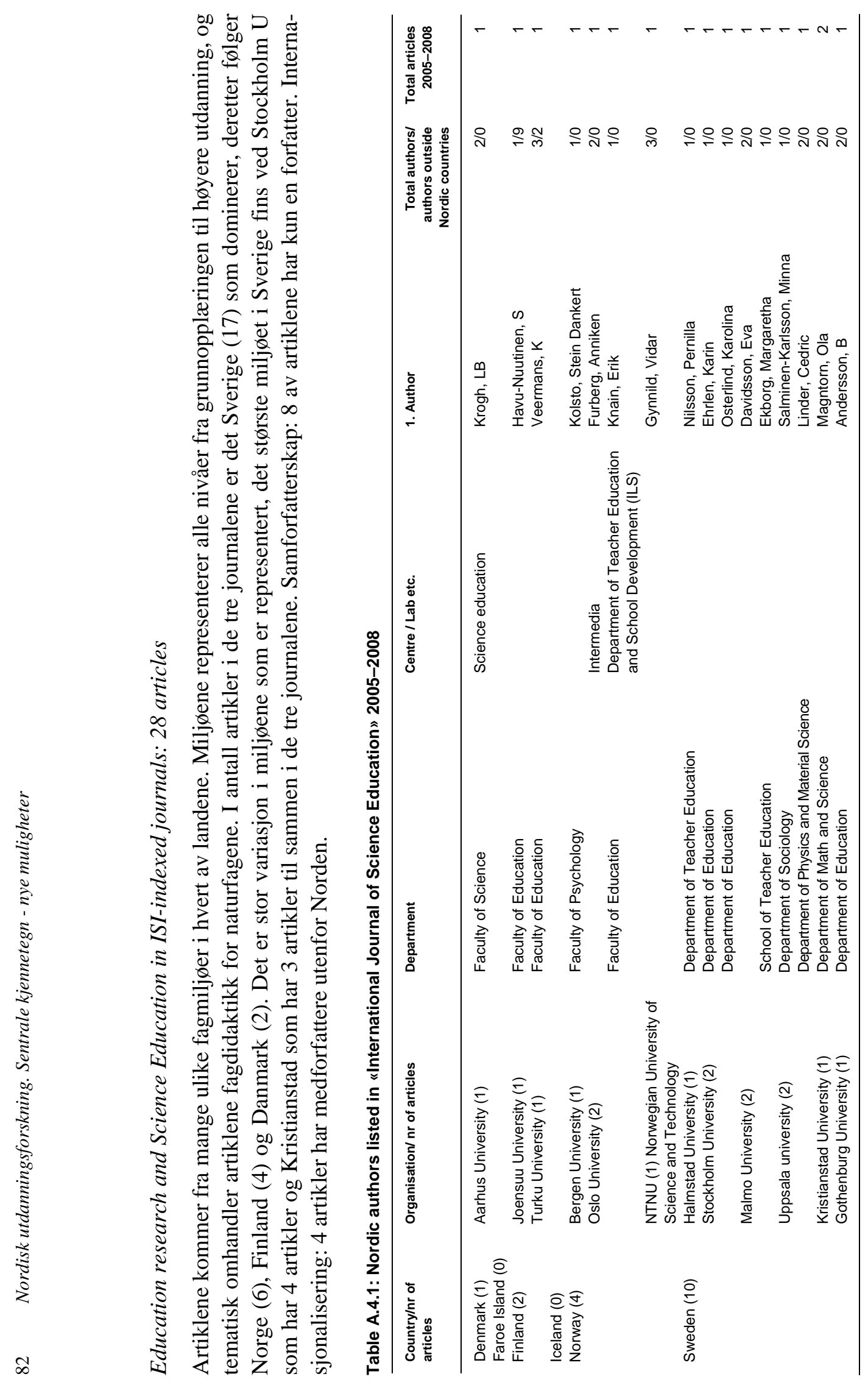




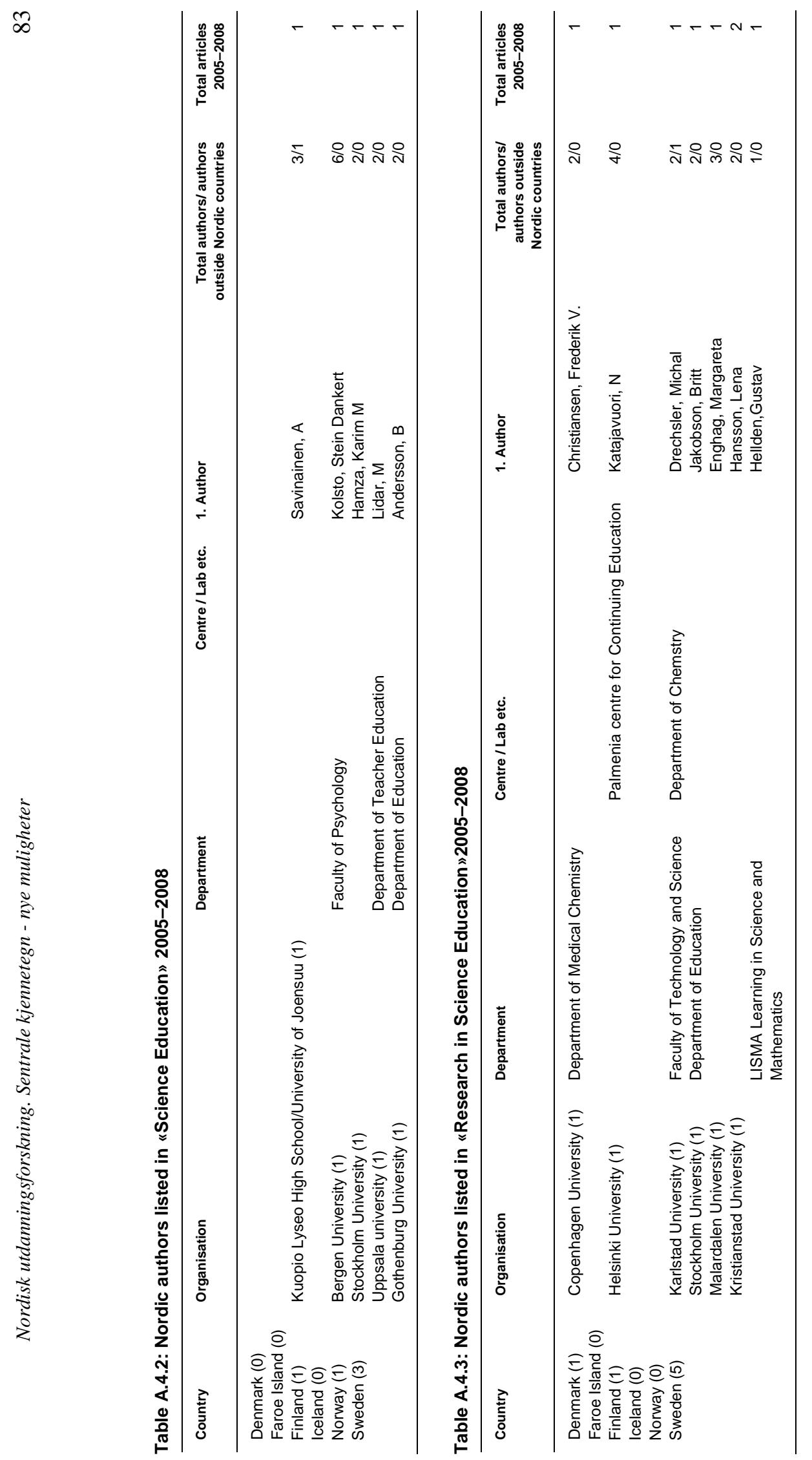




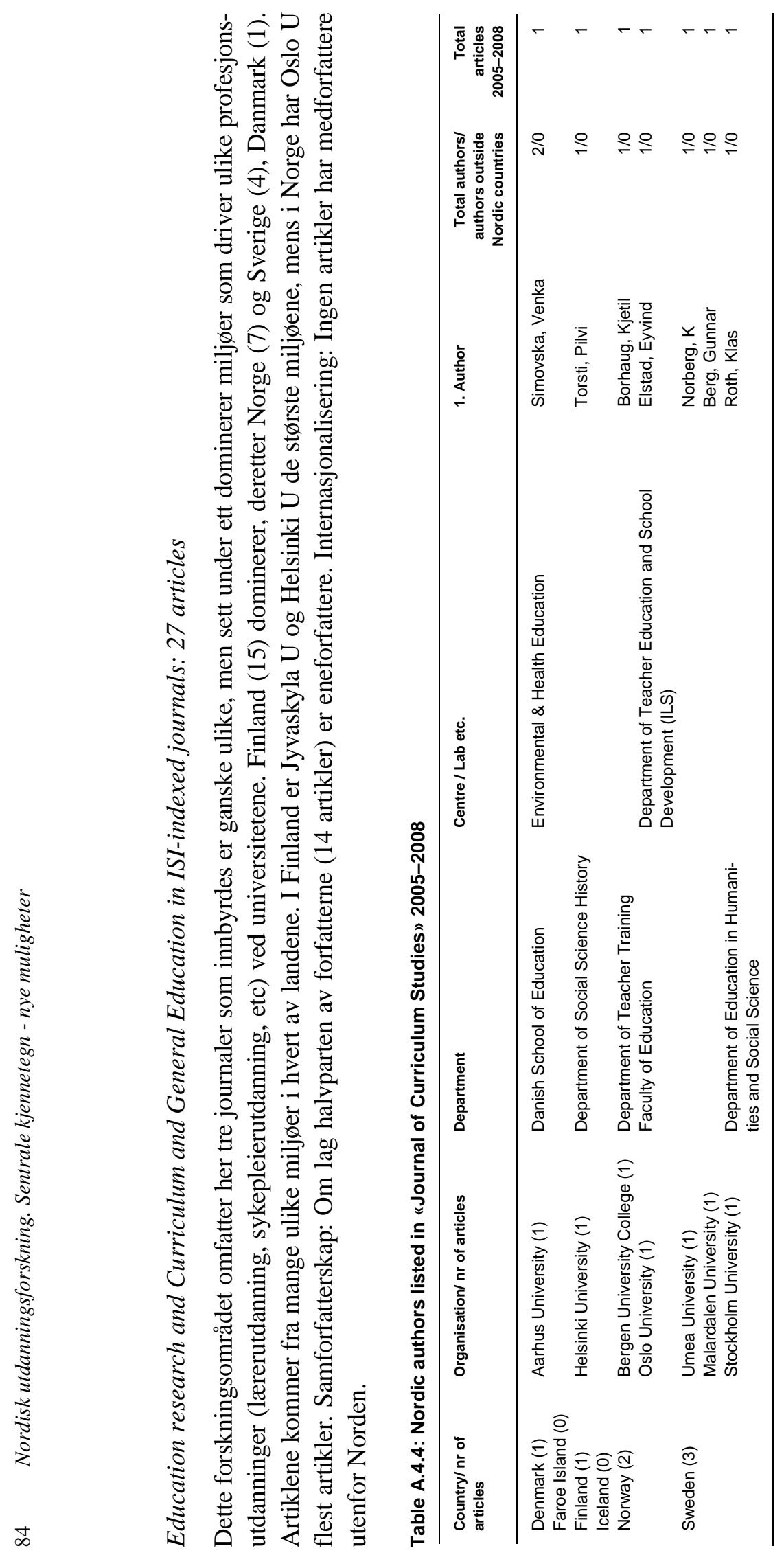




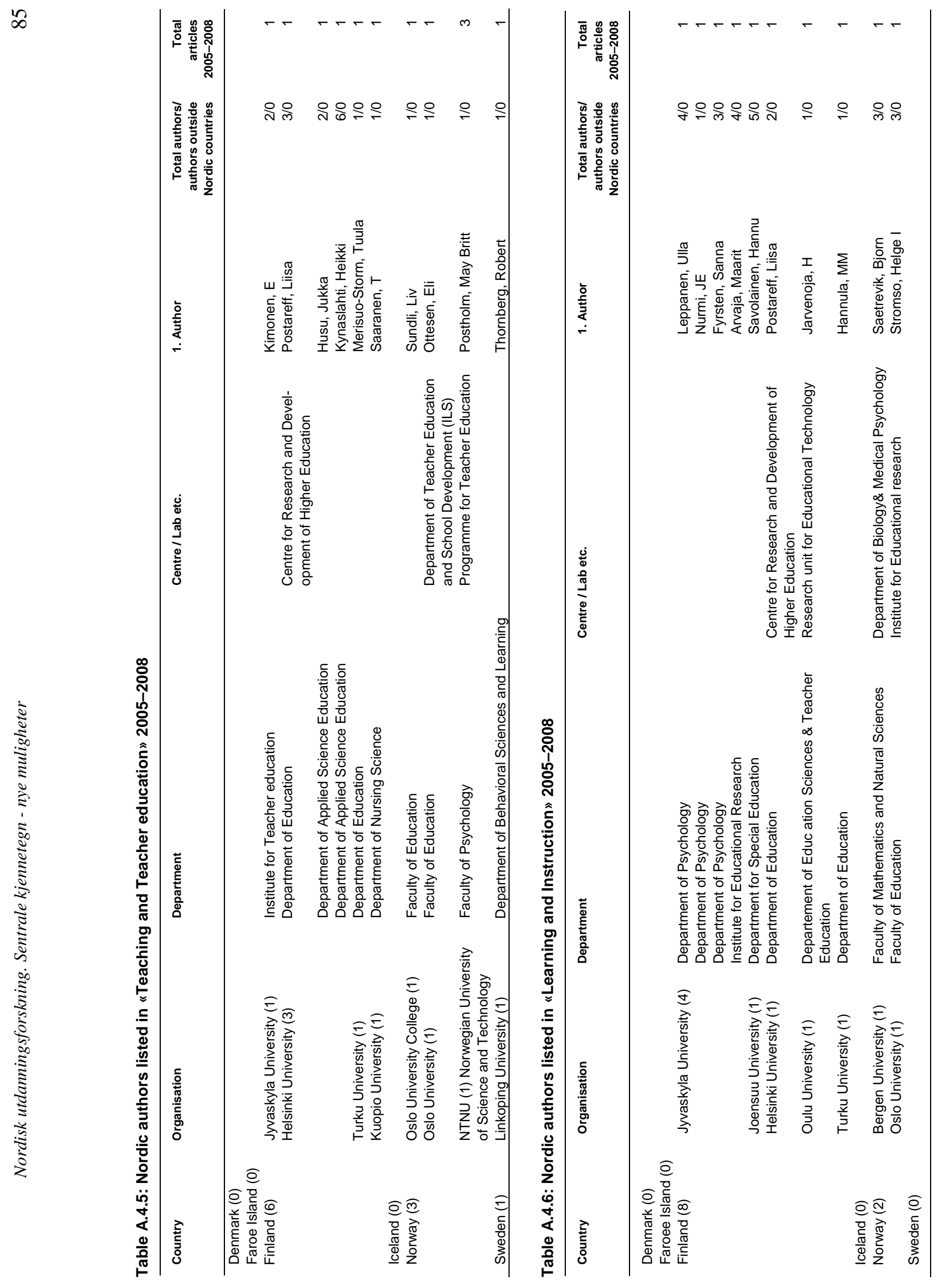




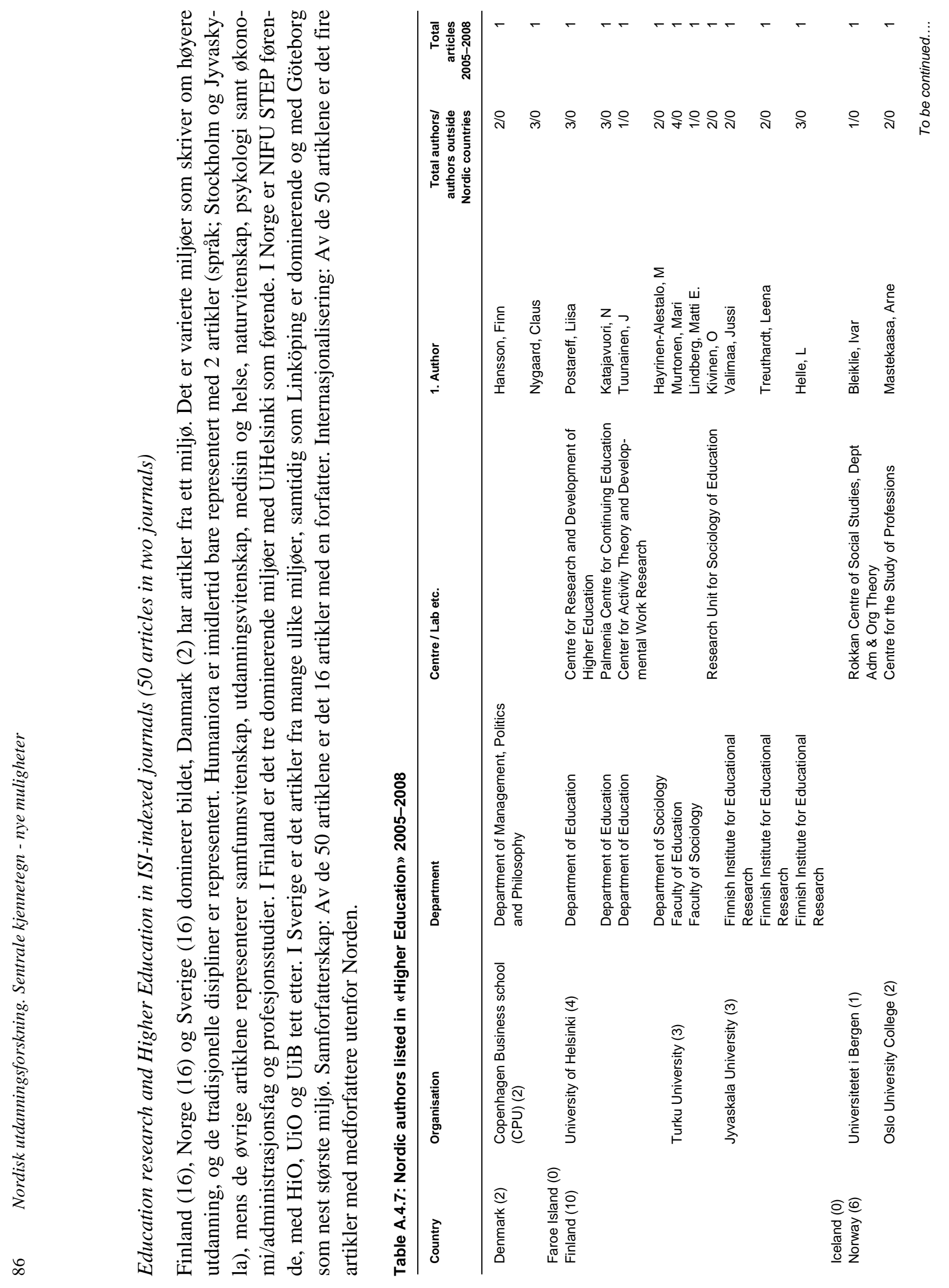




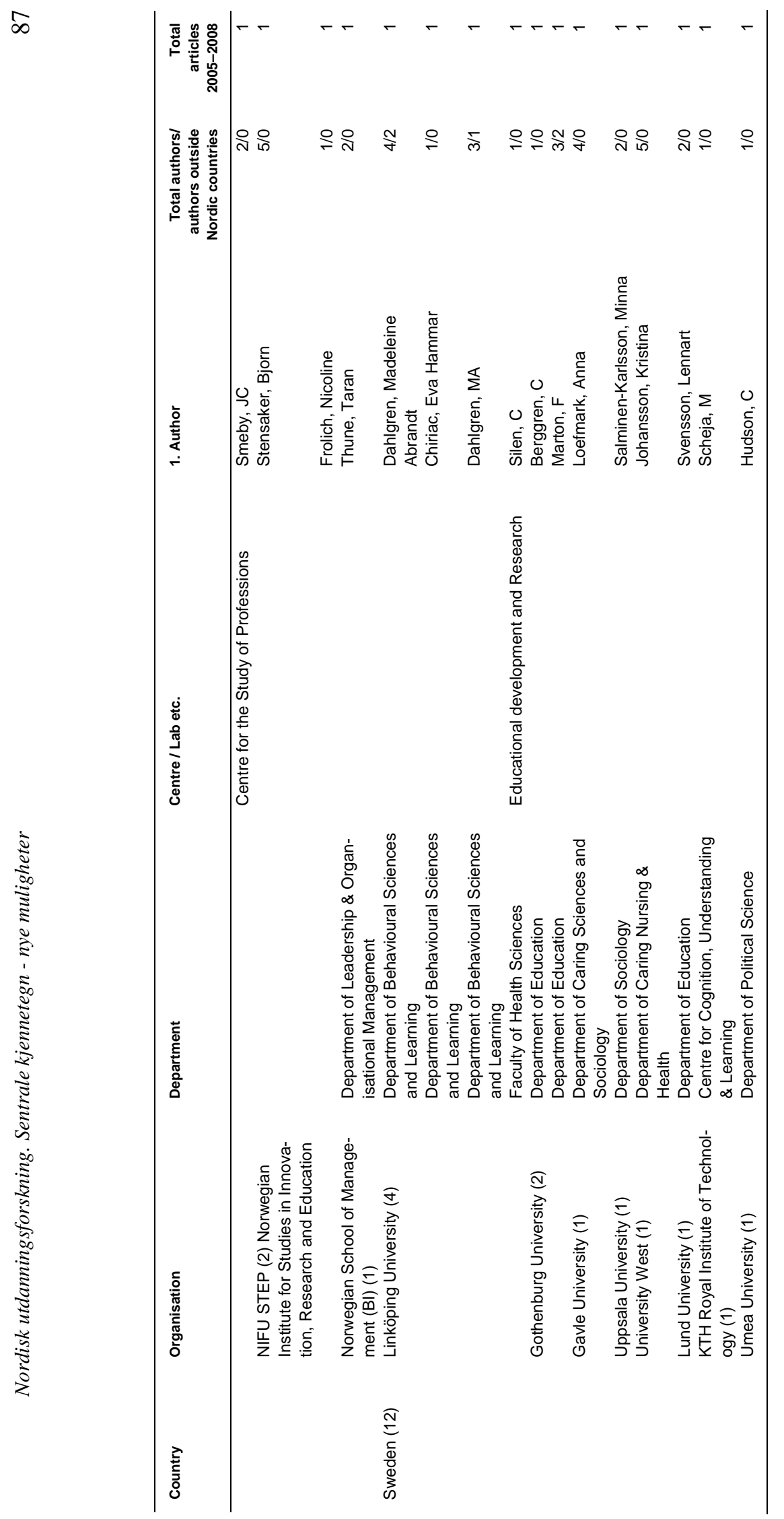




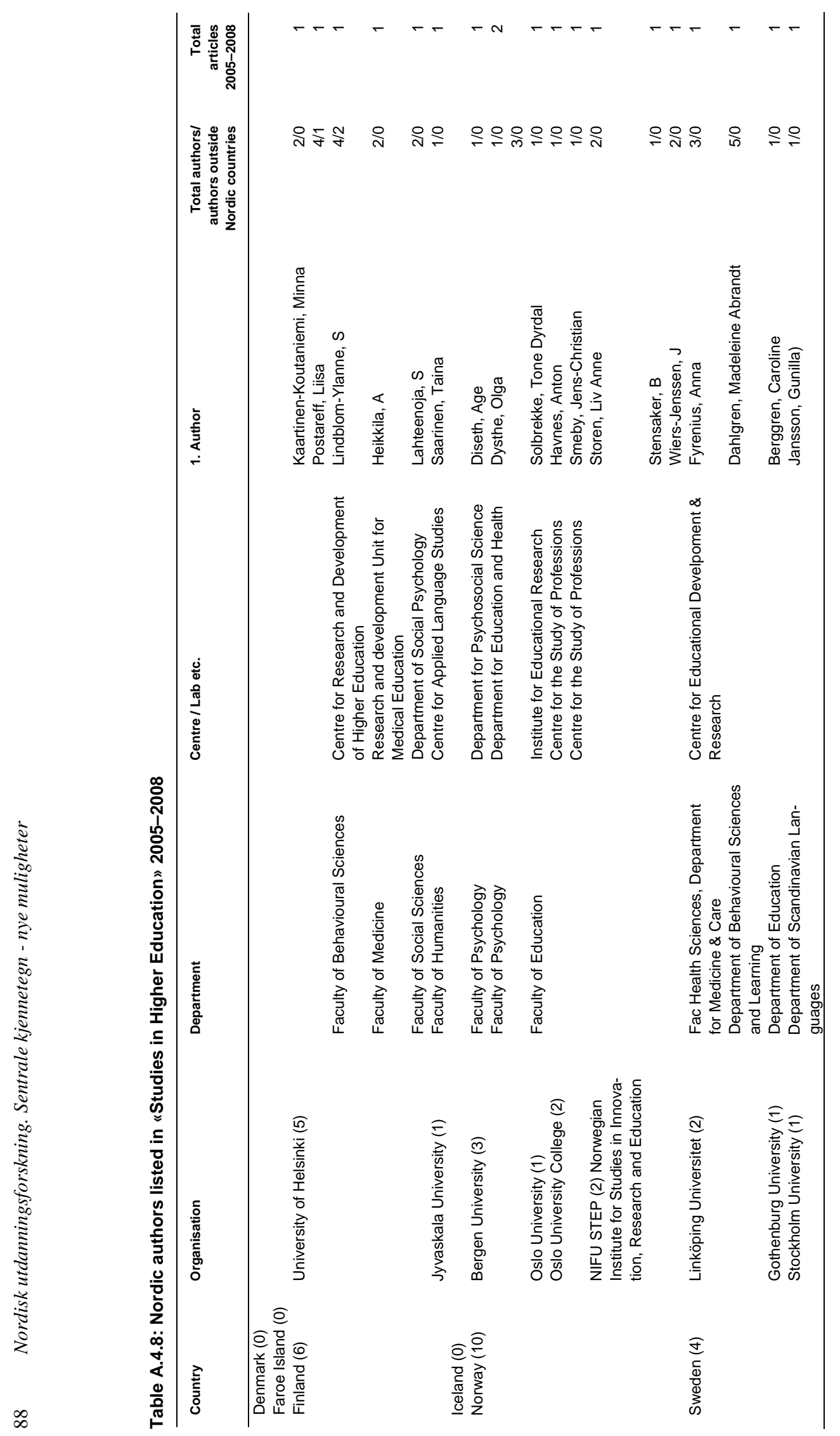


$\infty$

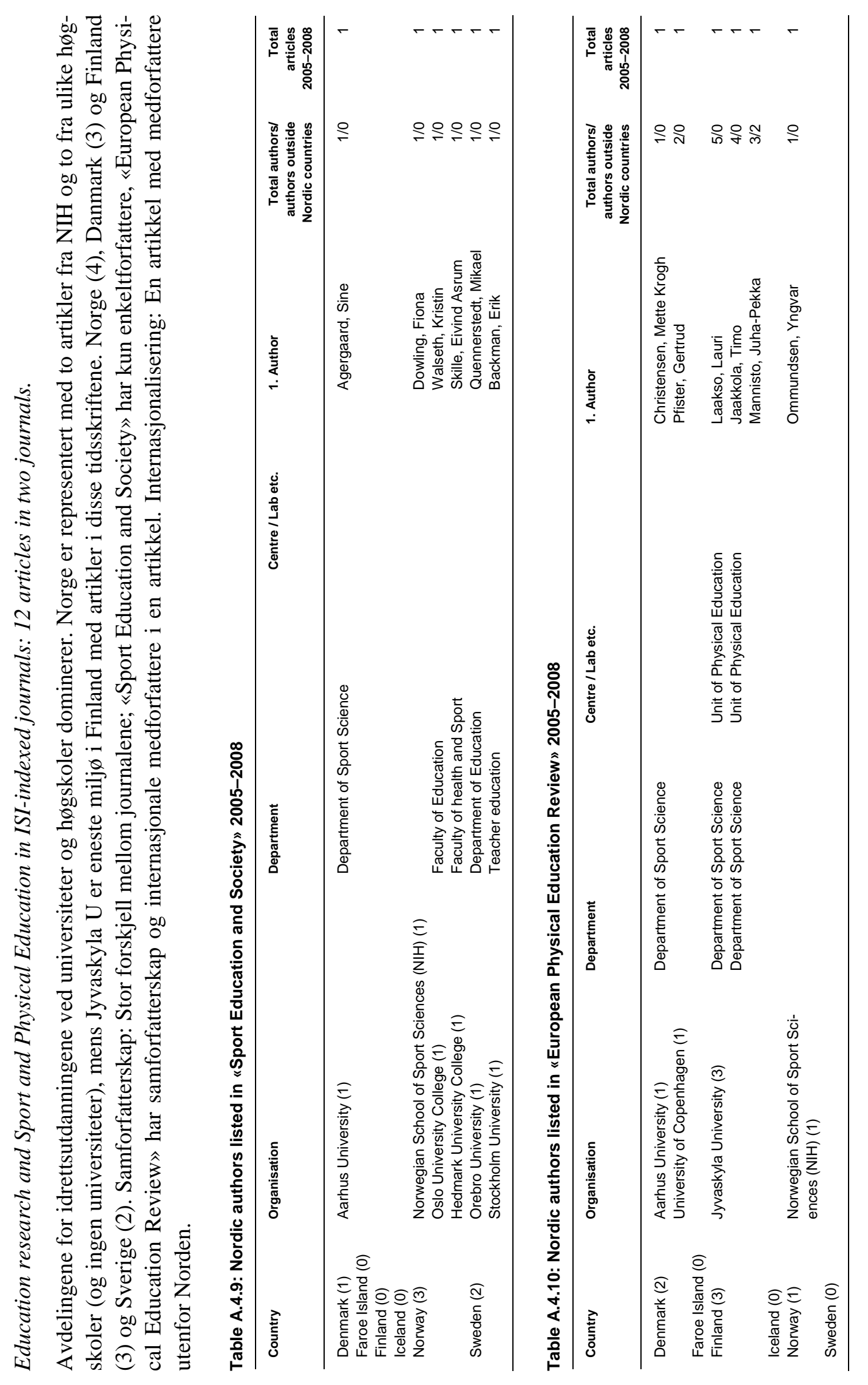




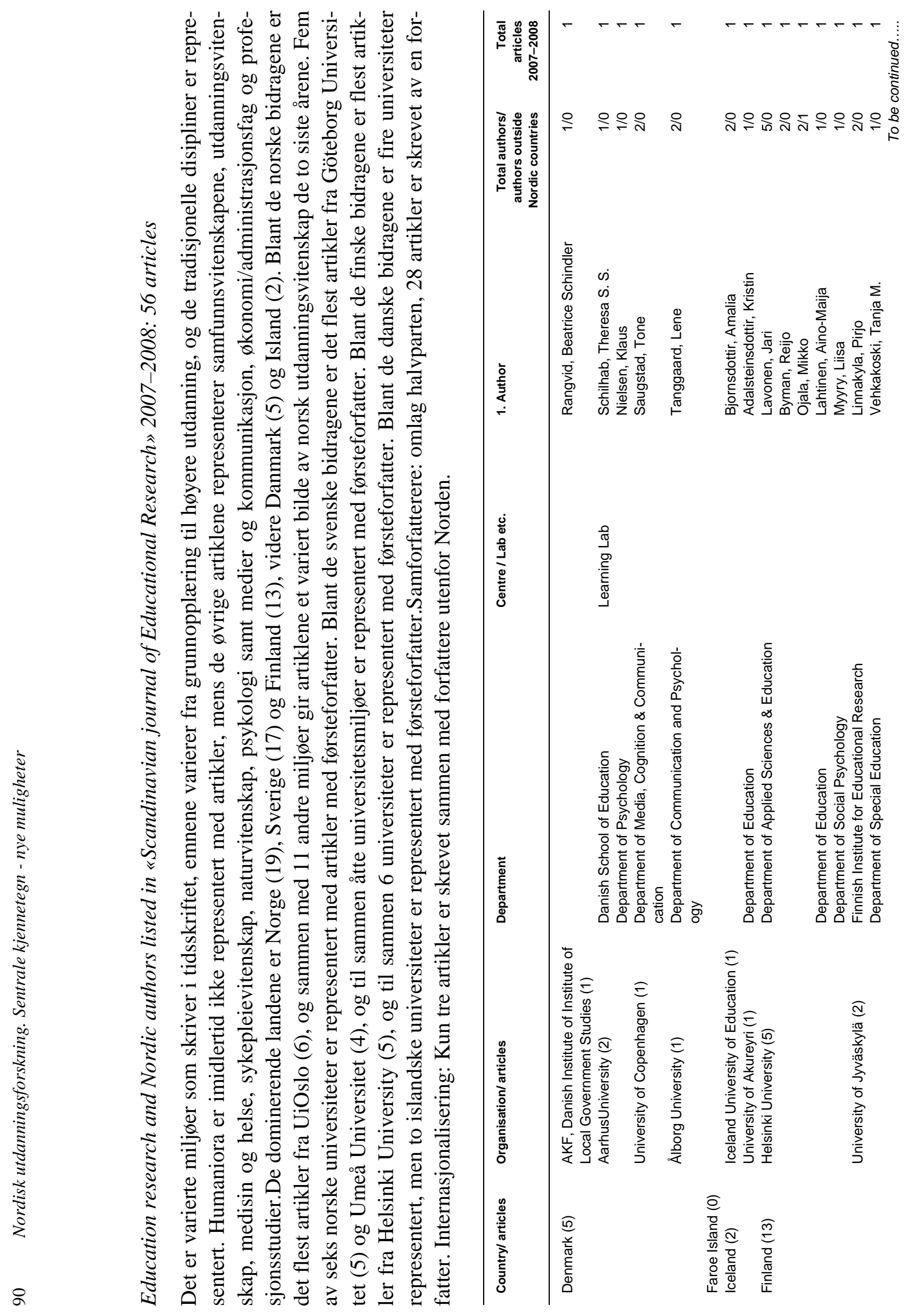




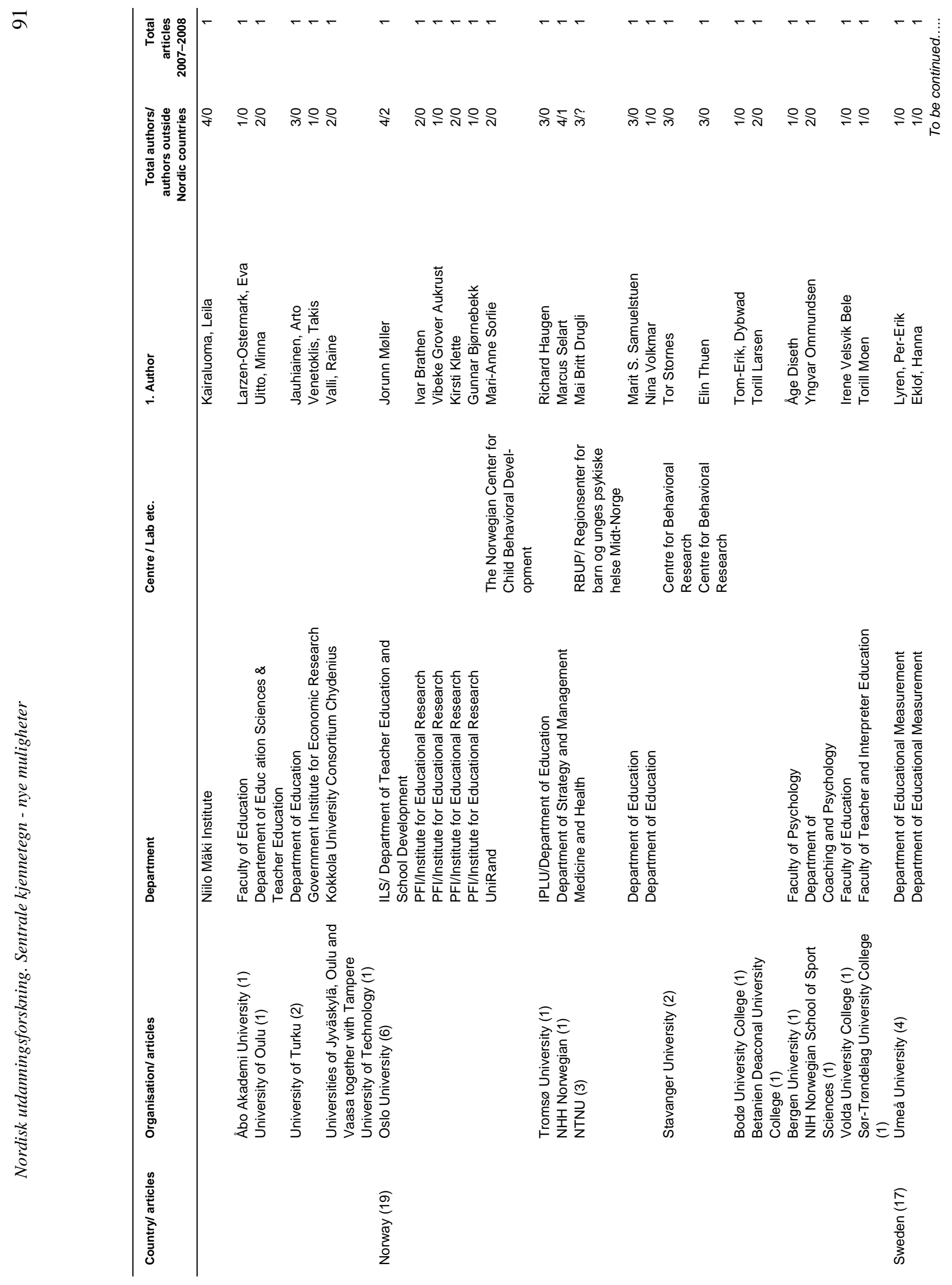




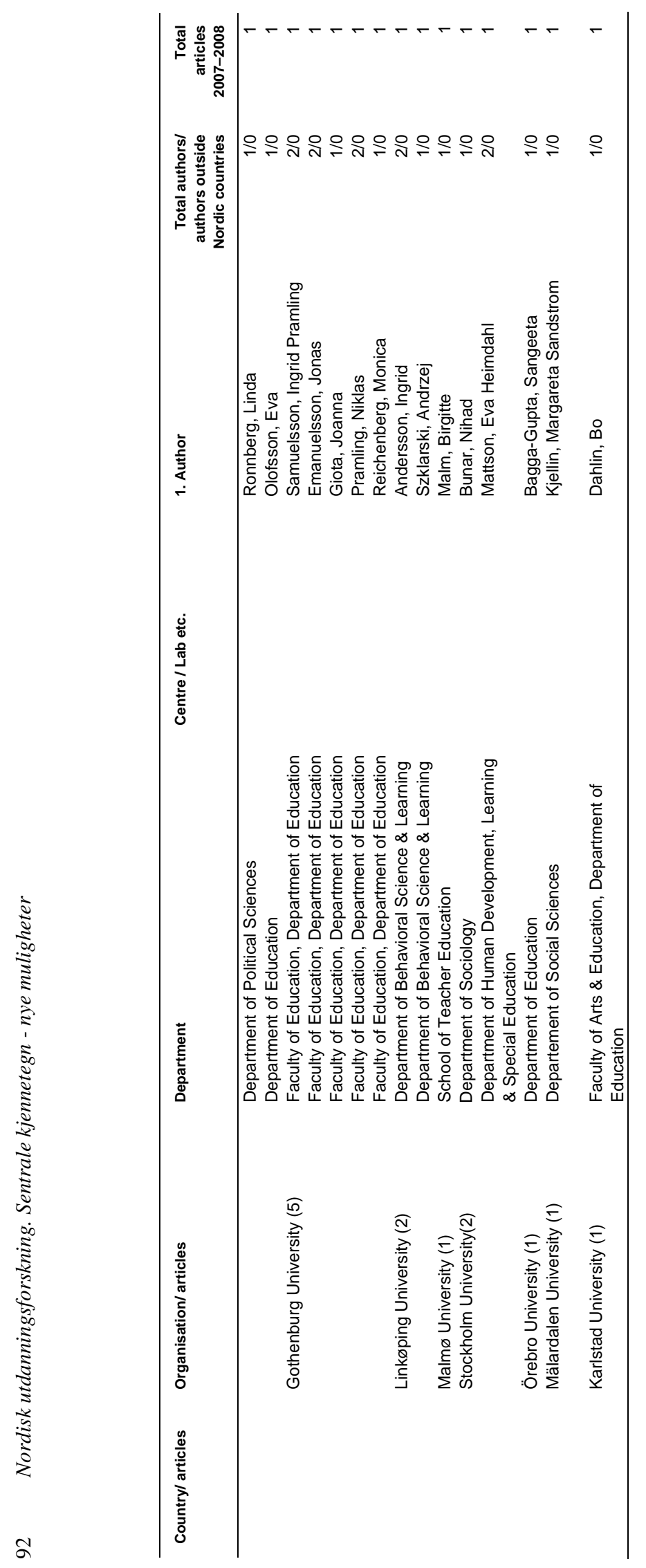

